TRADITIONAL MEDICINE AND PHARMACOLOGY. ACHIEVEMENTS, INNOVATIONS, AND ALTERNATIVES

\title{
2.6 Хірургічне лікування глибоких термічних та травматичних дефектів верхньої кінцівки
}

\subsection{1 Загальні положення}

Дефекти м'яких тканин верхньої кінцівки після травм та опіків при неналежному їх відновленні призводять до інвалідності та порушень якості життя [375]. Впродовж останнього часу реконструктивна хірургія активно розвивається і вдосконалюється для забезпечення максимального відновлення порушених функцій кінцівки та естетичних потреб [376]. В арсенал хірургічних засобів включається низка варіантів для закриття ран - первинне ушивання, шкірні трансплантати, місцеві та регіональні клапті, клапті 3 віддалених ділянок та вільна мікросудинна пересадка. Однак вибір найбільш придатного методу може бути складним процесом і найчастіше залежить від кожної конкретної ситуації [377]. Одним з найбільш впливових факторів $є$ втрата тканин, включаючи анатомічну локалізацію, розміри дефекту, місце, глибину, орієнтацію та складові структури.

Закрити дефекти м'яких тканин верхньої кінцівки неможливо за допомогою простих методів, таких як загоєння вторинним натягом або первинним ушиванням і слід застосовувати інші методи. Пересадка шкіри вимагає васкуляризованого ранового ложа для прийому трансплантата i не підходить для закриття дефектів над сухожилками та кістками з вівдсутністю паратенону або окістя. Крім того, висока можливість виникнення контрактур, рубцевої трансформації тканин та недостатня чутливість обмежують їх успішне використання як основний спосіб реконструкції [377, 378].

Клаптева пластика місцевими тканинами чи вільна пластика клаптями забезпечує власне кровопостачання, тому часто використовується для закриття складних дефектів 3 оголенням сухожиль і кісток. Однак, при застосуванні вмісцевих клапті або клаптів з віддалених анатомічних ділянок, слід враховувати декілька факторів. По-перше, повинно бути обраний найпростіший метод, який забезпечує адекватний об'єм м'яких тканин і забезпечує максимальне відновлення чи покращення функції разом 3 
TRADITIONAL MEDICINE AND PHARMACOLOGY. ACHIEVEMENTS, INNOVATIONS, AND ALTERNATIVES

найменшою деформацією донорської ділянки. По-друге, при можливості, використовувати тканини близькі по текстурі, кольору та об’єму [379,380].

Крім цього необхідно враховувати функціональні і естетичні ділянки верхньої кінцівки, які розділяють руку на окремі регіони, з їх унікальними функціональними та естетичними властивостями.

Для поглибленого вивчення особливостей клінічного перебігу глибоких термічних та травматичних уражень верхніх кінцівок та можливостей хірургічної корекції цих пошкоджень нами було відібрано 93 пацієнти, з яких у 12 постраждалих постерігались ураження обох верхніх кінцівок.

Основна частина постраждалих отримала травму електричним струмом - 57(61,3\%), опіки полум'ям були - у 17(18,3\%) та іншими агентами - у $19(20,4 \%)$.

Обмежені ураження тільки верхніх кінцівок та кисті було у 59(63,4\%) постраждалих. У 34(36,6\%) пацієнтів серед супутніх уражень найчастіше пошкоджувались нижні кінцівки $(15(44,1 \%))$, у меншій мірі спостерігались ураження тулуба 9(26,5\%), голови та шиї 4(11,8\%) і множинні ураження $6(17,6 \%)$.

Шкірно-жировими та шкірно-фасціальними клаптями закривали невеликі дефекти в ділянках тильних та долонних поверхонь фаланг пальців, проксимальних міжфалангових суглобів, ділянці тенара та гіпотенара, а також ліктьової ямки. Клапті формували з бічних поверхонь уражених сегментів.

Пластичне закриття ран при дефіциті місцевих тканин здійснили невільними шкірно-жировими клаптями на тимчасовій живлячій ніжці 3 віддалених ділянок. Ранові дефекти локалізувались на кисті, пальцях, променево-зап’ястковому суглобі та передпліччі.

Поряд 3 важкістю пошкодження, при тяжкій термічній травмі кінцівки порушення кровообігу і обміну в тканинах в зоні ураження обумовлюють використання втручань, які б відновили кровообіг в ураженому сегменті.

Існує концепція непрямої реваскуляризації пошкоджених тканин 3 можливим відновленням у них кровообігу. Для реваскуляризації глибоких 
TRADITIONAL MEDICINE AND PHARMACOLOGY. ACHIEVEMENTS, INNOVATIONS, AND ALTERNATIVES

ранових дефектів відповідають клапті з гарантованим осьовим кровообігом, використання яких дозволяє повноцінно усувати дефект шкірних покривів, створювати непряму васкуляризацію глибоких структур, дозволяє раніше починати реабілітацію та скорочувати терміни лікування. При цьому здійснювали пластику повноцінними тканинами 3 формуванням певних клаптів. Особливості кровозабезпечення поверхневих тканин верхніх кінцівок давало можливість формувати клапті як на проксимальній, так і на дистальній ніжках.

Використання клаптів 3 осьовим кровообігом застосовували у двох варіантах - на постійній ніжці та на тимчасовій судинній ніжці. Перевагу тому чи іншому засобу переміщення тканин надавали в залежності від особливостей перебігу місця ураження - пошкодження судин, поширеністю ураження, важкості стану постраждалого, функціональних змін в ураженому сегменті тощо.

2.6.2 Хірургічне лікування дефектів кисті та дистальних відділів передпліччя.

\subsubsection{1 Клапті кисті}

Хірургічне лікування термічних уражень пальців являє головну роль у відновленні функції кисті.

Для більш чіткого розуміння можливостей пластичного закриття дефектів на пальцях виділили 3 анатомічних частини:

- дистальну - від прокимального міжфалангового суглоба (ПМФС) з включенням середньої та нігтьової фаланг;

- середню - рівень ПМФС;

- проксимальну - від ПМФС з включенням проксимальної фаланги.

Дефекти долонної та тильної поверхонь також потребують різних варіантів реконструкції [380]. 
TRADITIONAL MEDICINE AND PHARMACOLOGY. ACHIEVEMENTS, INNOVATIONS, AND ALTERNATIVES

\subsection{V-Y - клапоть ковзання}

V-Y - клапоть був популяризований Atasoy E. et al. (1970) [381]. Застосування V-Y - клаптя показано для пластики поперечних чи косих дефектів фаланг пальців 3 оголенням кістки, а також для відновлення чутливості торців кукс пальців. Цей клапоть забезпечує повне відновлення м'яких тканин за текстуральними та сенсорними властивостями. Клапоть включає нейросудинні пучки які забезпечують його живлення та чутливість [380].

Розмітку клаптя здійснюють у вигляді літери «V» на долонній поверхні ураженої фаланги. Верхівка клаптя не повинна виходити проксимально за межі міжфалангової складки. Основа простягається до бічних поверхонь дефекту. По наміченим орієнтирам розрізаються м'які тканини до окістя фаланги і частково мобілізуються у проксимальному відділі шляхом підсікання фіброзно-жироваго прошарку. Після просунення клаптя на дефект, проксимальна частина закривається як «Ү», а клапоть підшивається до країв ранового дефекту (рис. 1).

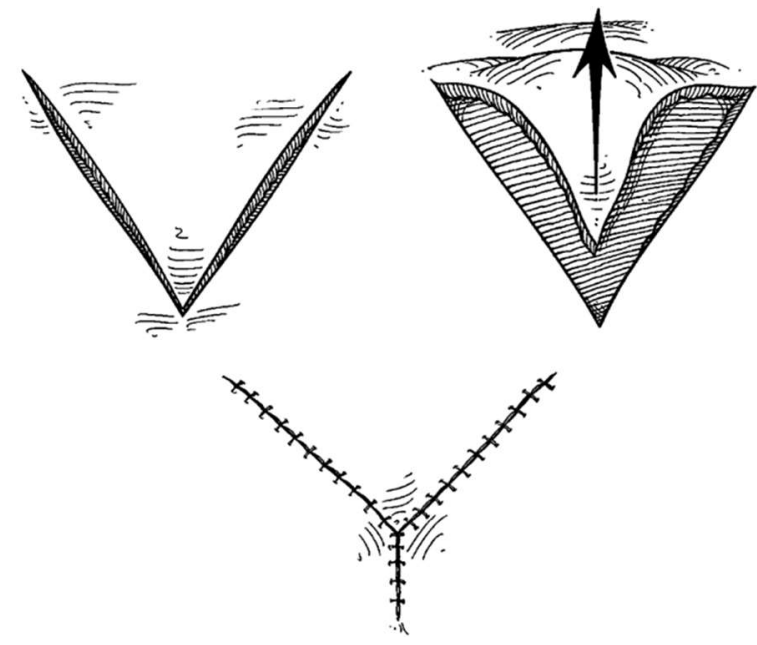

Рис. 1. Схема формування V-Y - клаптя

Клінічний приклад. Хворий П. 34 років отримав загальне переохолодження, відмороження кистей рук II - IV ступеня. На 20 добу сформувався некроз дистальних фаланг 2-5 пальців та середньої фаланги 4 пальця. Здійснено некректомії по типу нетипових ампутацій фаланг пальців на рівні некрозу. На долонних поверхнях середніх фаланг 2, 3 та 5 пальців та 
TRADITIONAL MEDICINE AND PHARMACOLOGY. ACHIEVEMENTS, INNOVATIONS, AND ALTERNATIVES

середньої фаланги 4 пальця сформовано шкірно-підшкірні V-подібні клапті, які за текстуральними властивостями близькі до тканин дефекту. Після їхньої часткової мобілізації клапті шляхом ковзання переміщені на торці кукс фаланг пальців та фіксовані до країв. Донорські дефекти ушиті (рис. 2).

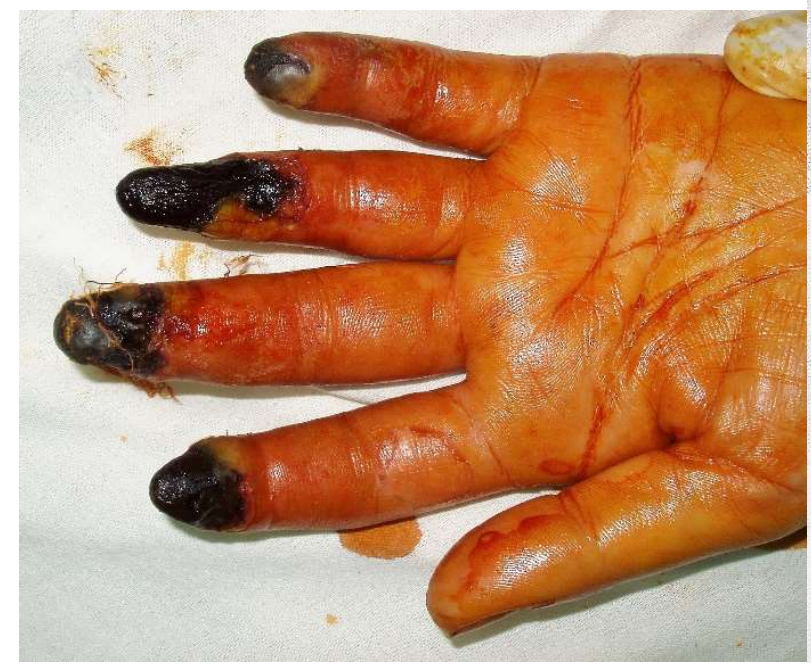

A

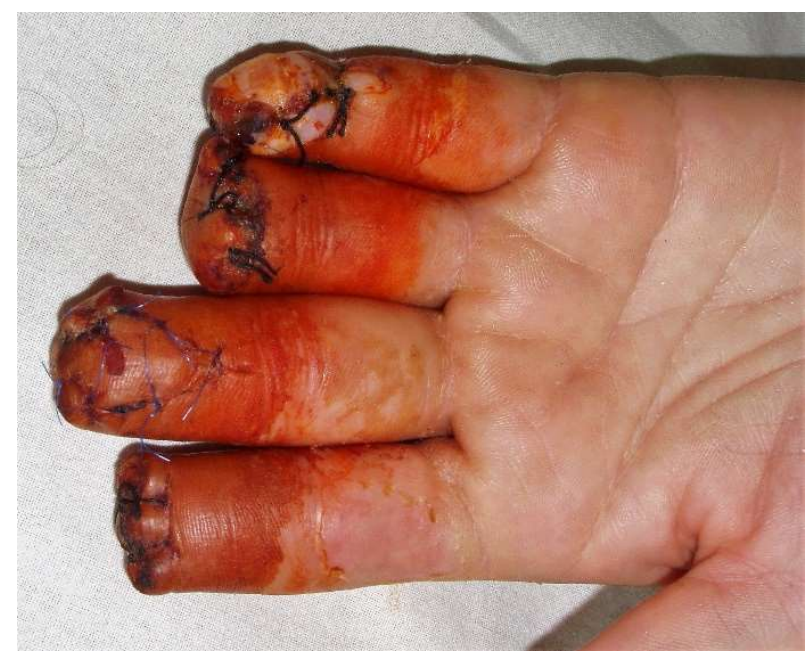

$\mathrm{B}$

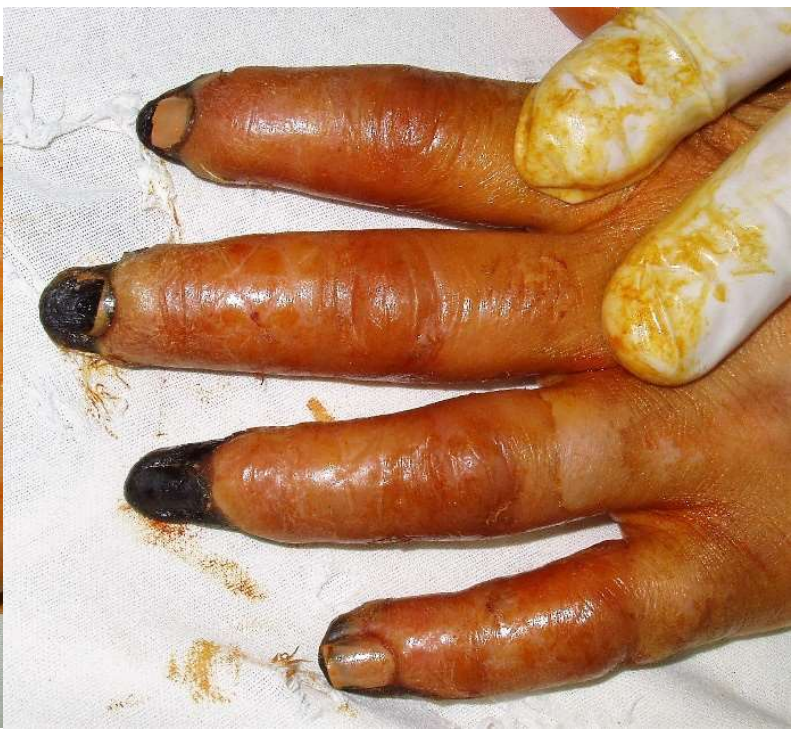

Б

Рис. 2. (А, Б) Некротичні дефекти нігтьових (2, 3, 5 пальці) та середньої (4 палець) фаланг пальців після відмороження. (B, Г) після висічення некрозу здійснено пластику V-Y клаптями.

\subsubsection{2. Клапоть ділянки тенара}

Свого розповсюдження клапоть набув після публікацій робіт Flatt A.F. $(1955,1957)$ [380]. Показанням для застосування тенар-клаптя є долонні чи тильні дефекти нігтьових фаланг пальців завдяки його близькими текстуральними властивостями до тканин дефекту. Однак, при застосуванні 
TRADITIONAL MEDICINE AND PHARMACOLOGY. ACHIEVEMENTS, INNOVATIONS, AND ALTERNATIVES

клаптя необхідна тривала фіксація ушкодженого пальця і кисті у вимушеному положенні.

Формування клаптя здійснюється після визначення місця його розташування та форми дефекту шляхом підведення ранової поверхні пальця до ділянки тенара. Формується клапоть подібний до форми та розміру дефекту з включенням всіх тканин до м'язової фасції. Після закриття донорської ділянки ушкоджений палець підводиться рановим дефектом під клапоть і фіксується окремими швами-трималками. Клапоть підшивається до дефекту. Через 3 тижні здійснюють 2 етап - відсічення живлячої ніжки клаптя і його моделювання на місці дефекту (рис. 3).
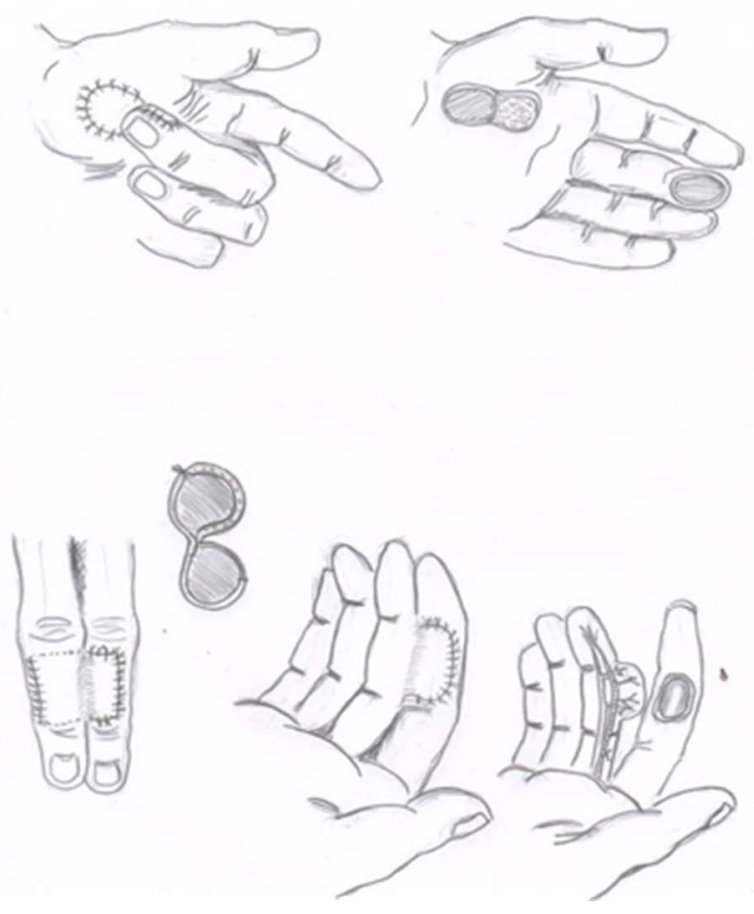

Рис. 3. Схема формування клаптя з ділянки тенара (зверху) та перехресного клаптя (cross-flap) (знизу).

Клінічний приклад. Хворий О. 43 років отримав низьковольтне ураження електричним струмом 4 та тильно-променевої поверхні середньої фаланги 3 пальців. У зв'язку з декомпенсованим порушенням кровообігу у 4 пальці здійснено ампутацію пальця на рівні ПМФС з первинним ушиванням кукси. Після видалення некрозу на тильно-променевій поверхні середньої фаланги 3 пальця оголилась частина кістки. Для закриття дефекту в ділянці 
TRADITIONAL MEDICINE AND PHARMACOLOGY. ACHIEVEMENTS, INNOVATIONS, AND ALTERNATIVES

тенара сформований шкірно-жировий клапоть 4,5 х 3 см. 3 палець підведено до клаптя і фіксовано до кисті швами-трималками. Клапоть фіксований к краям рани. Через 3 тижні здійснено відсічення живлячої ніжки і моделювання клаптя (рис. 4).

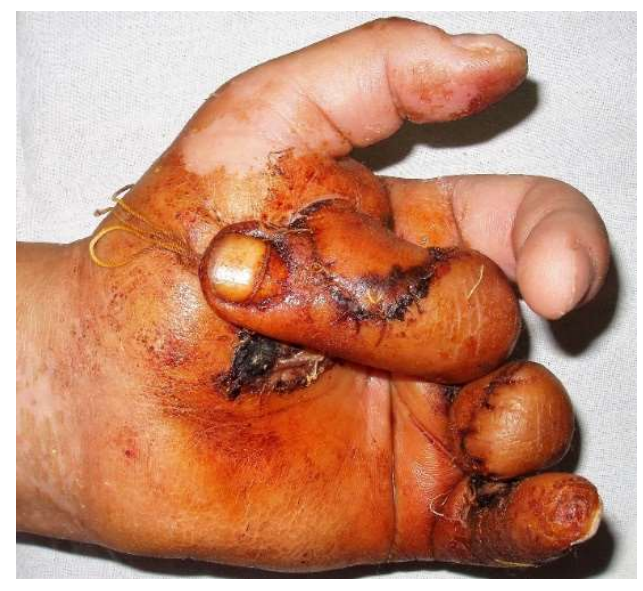

A

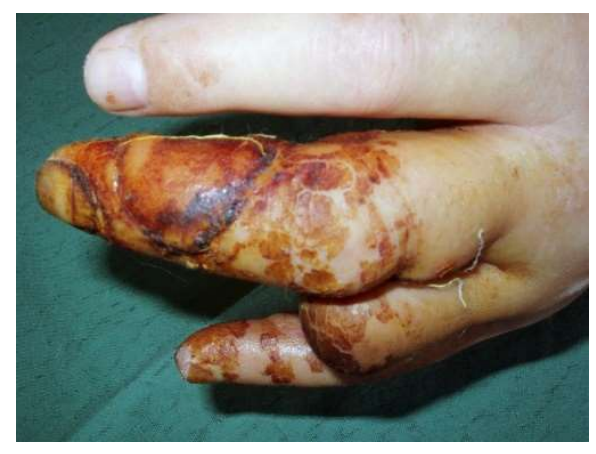

Б

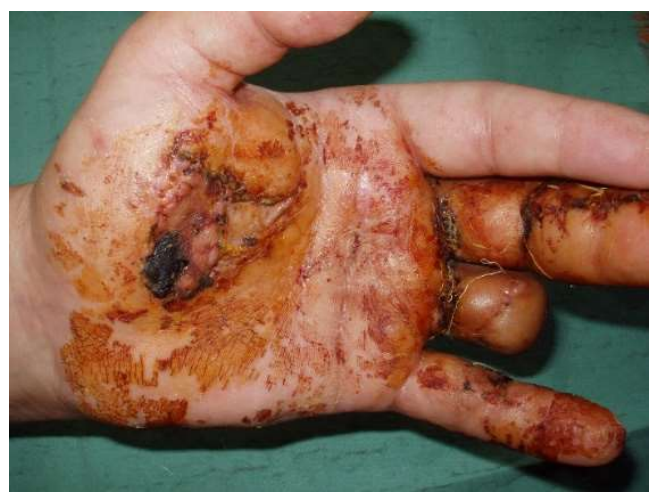

B

Рис. 4. (А) Пластика дефекту тенар-клаптем тильно-променевої поверхні дистальної частини 3 пальця; (Б) Найближчий післяопераційний період; (В) Вигляд донорської ділянки.

\subsubsection{3. Перехресний клапоть (cross-flap)}

Перехресний клапоть був вперше описаний Cronin T.D. (1951) [382]. Показанням для застосування цього клаптя $є$ дефекти тканин середньої чи дистальної фаланг пальців. Найчастіше використовують 3 палець для закриття дефектів долонної поверхні 2 та 4 пальців. Формування клаптя здійснюють на тильній поверхні донорського пальця по шаблону ранового дефекту 3 наближенням до прямокутної форми. Розміри клаптя повинні трохи 
TRADITIONAL MEDICINE AND PHARMACOLOGY. ACHIEVEMENTS, INNOVATIONS, AND ALTERNATIVES

перевищувати розмір дефекту щоб уникнути надмірного крайового натягу при підшиванні. У клапоть включаються всі шари тканин тилу донорського пальця над паратеноном сухожилля розгинача. Після підняття клаптя, останній переміщується на $180^{\circ}$ рановою поверхнею до дефекту у вигляді книжної сторінки і підшивається до країв. Пальці фіксуються один до одного окремими швами. Донорська ділянка закривається вільним трансплантатом. Через 3 тижні виконують 2 етап - відсічення живлячої ніжки та моделювання клаптя (рис. 5).

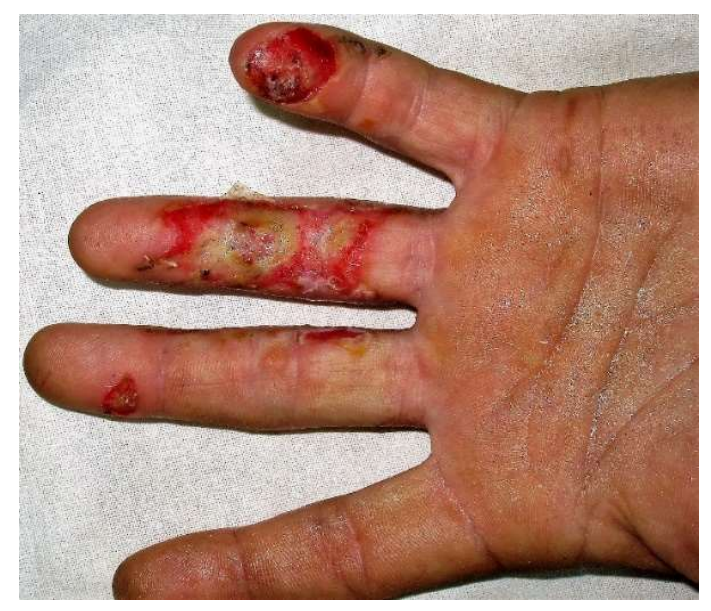

A

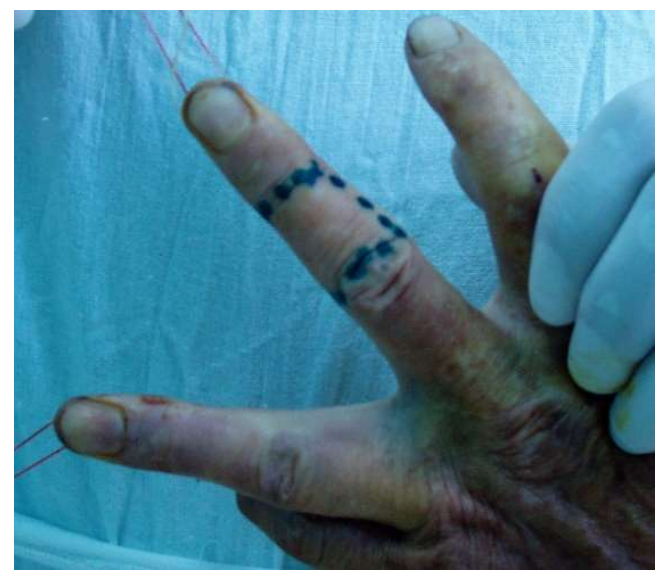

B

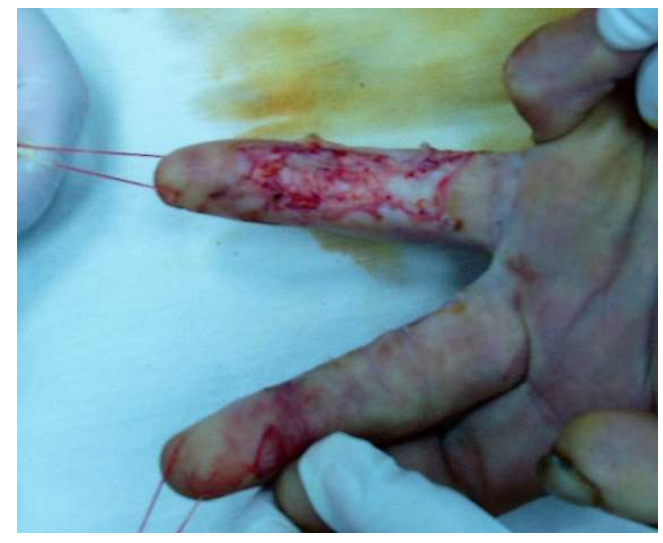

Б

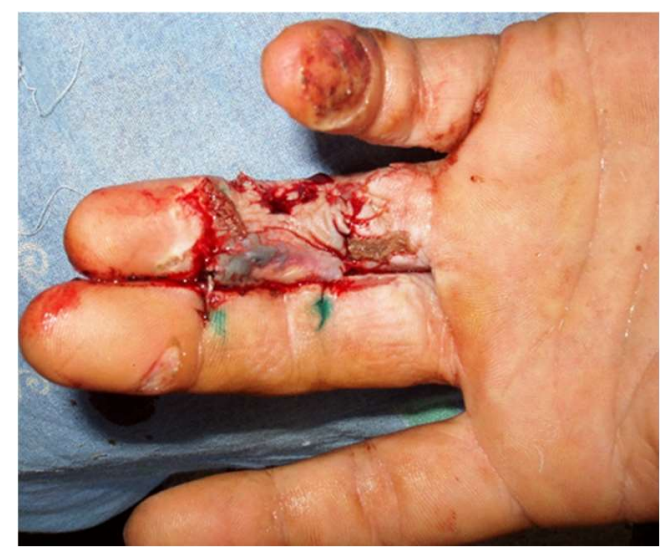

$\Gamma$

Рис. 5. (А) ураження електричним струмом долонної поверхні середньої фаланги та ПМФС 4 пальця; (Б) видалення некрозу; (В) розмітка перехресного клаптя тилу 3 пальця; (Г) пластика перехресним клаптем з тилу основної фаланги 3 пальця. 
TRADITIONAL MEDICINE AND PHARMACOLOGY. ACHIEVEMENTS, INNOVATIONS, AND ALTERNATIVES

\subsubsection{4. Острівцевий гомодигітальний клапоть}

Клапоть вперше описаний Weeks P.M, Wray R.C. у 1973 році [381]. Клапоть базується на радіальному чи ліктьовому власному пальцевому судинному пучку і може формуватися як на проксимальній, так і на дистальній судинних ніжках. Показанням для застосування клаптя є дефекти середньої та нігтьової фаланг пальців, а також дистального міжфалангового суглоба (ДМФС) (на дистальній ніжці) та п’ястко-фалангового суглоба (ПФС) (на проксимальній ніжці).

Клапоть формується на бічній поверхні проксимальної фаланги пальця після нанесення шаблону ранового дефекту. По наміченим орієнтирам розсікається шкіра 3 м'якими тканинами на всю товщу і ідентифікується пальцевий судинний пучок. При формуванні клаптя на дистальній ніжці розріз шкіри здійснюється дистально у проекції живлячої судинної ніжки до ДМФС і краї рани мобілізуються з утворенням ложа для судин. При виділенні ніжки відокремлюється пальцевий нерв, а судини лігуються біля проксимального краю клаптя. Ніжка виділяється разом 3 жировою клітковиною. Клапоть розвертається на $180^{\circ}$ і фіксується в місці дефекту. Донорська рана закривається вільним трансплантатом (рис. 6).

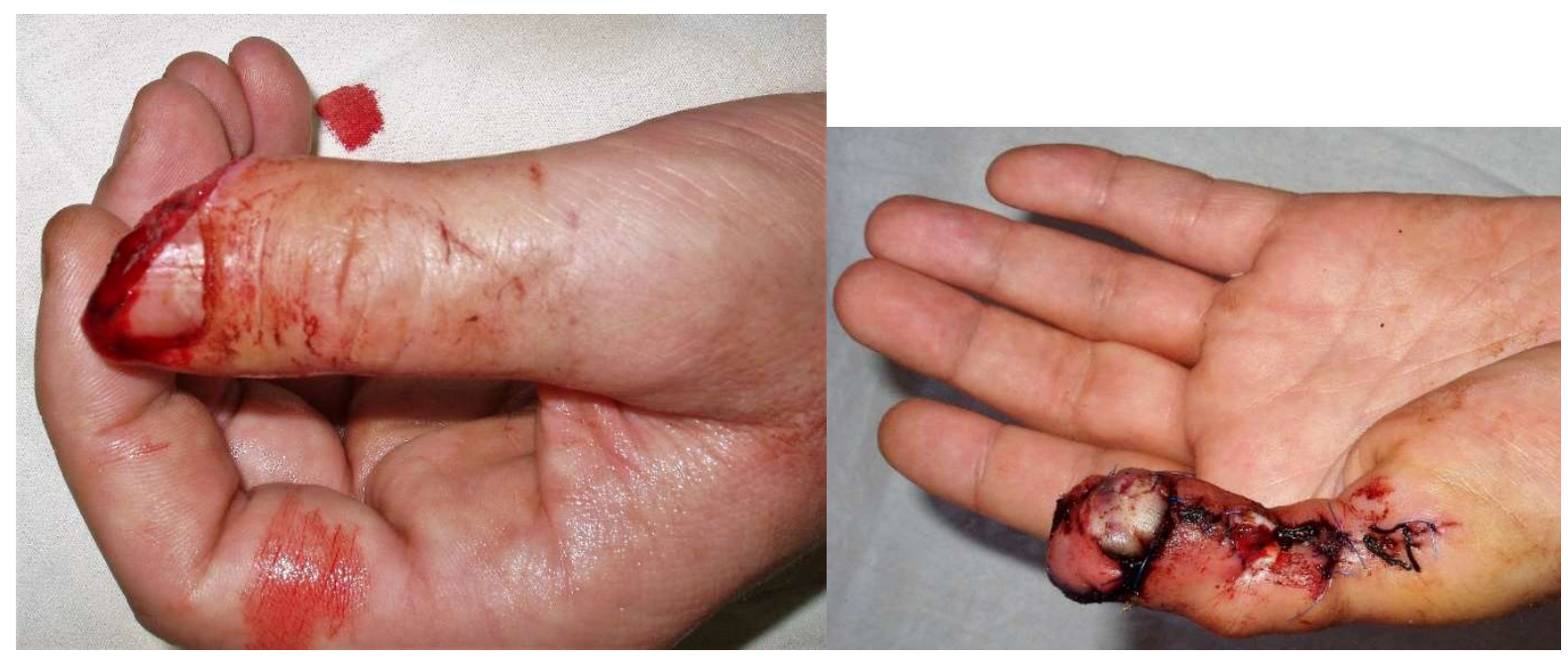

A

Б

Рис. 6. (А) Дефект нігтьової фаланги 1 пальця; (Б) пластика дефекту острівцевим гомодигітальним клаптем. 
TRADITIONAL MEDICINE AND PHARMACOLOGY. ACHIEVEMENTS, INNOVATIONS, AND ALTERNATIVES

\subsubsection{5. Острівцевий нейроваскулярний гетеродигітальний}

\section{клапоть}

У зв'язку з необхідністю відновлення не тільки шкірних покривів але й чутливості на долонній поверхні середньої фаланги III пальця здійснюється пластика нейро-васкулярним пальцевим клаптем (НВК) з бічної поверхні іншого пальця [383, 384].

Живлення тканин, що переміщуються, здійснюється власною пальцевою артерією, а венозний дренаж - венами тильної частини пальця. Іннервація ділянки відбувається власним долонним пальцевим нервом, який разом 3 артерією утворюють судинно-нервовий пучок. Пластика такими клаптями забезпечує, крім непрямої реваскуляризації ранового ложа, також і повноцінну його реіннервацію (рис. 7).

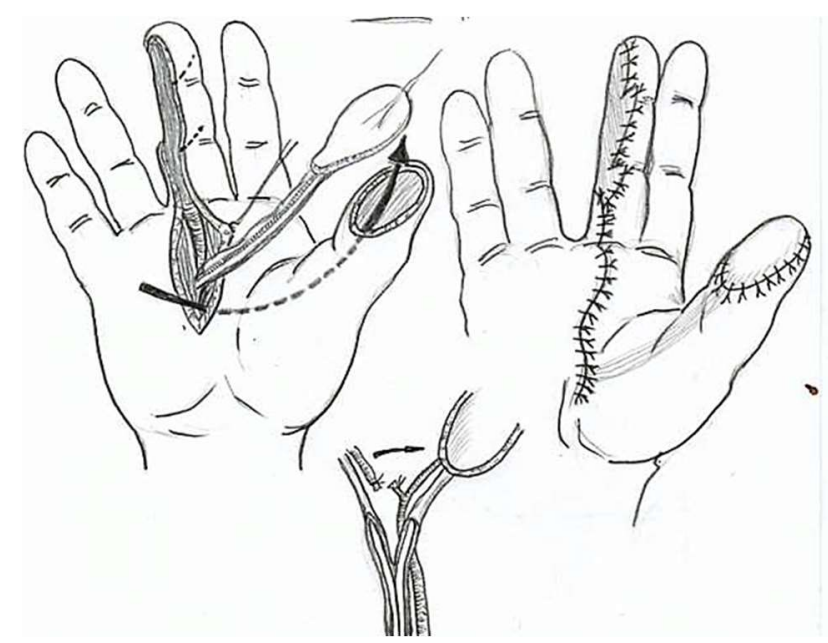

Рис. 7. Схема формування острівцевого нейроваскулярного гетеродигітального клаптя.

Клінічний приклад. Хворий Ц. 38 років поступив 3 ураженням електричним струмом низької напруги долонної поверхні основної фаланги 2 пальця правої кисті. Травма 2 години тому. Через 1 добу здійснено видалення щільного некротичного струпу на долонній поверхні основної фаланги 2 пальця. Для відновлення дефекту м'яких тканин та чутливості в ураженій ділянці на променевій стороні середньої фаланги 3 пальця сформовано нейросудинний острівцевий клапоть 3 включенням власної пальцевої артерії і 
TRADITIONAL MEDICINE AND PHARMACOLOGY. ACHIEVEMENTS, INNOVATIONS, AND ALTERNATIVES

нерву 3 пальця. Крізь утворене ложе, клапоть підведено до дефекту і підшито до країв рани. Післяопераційний період проходив без ускладнень (рис. 8).

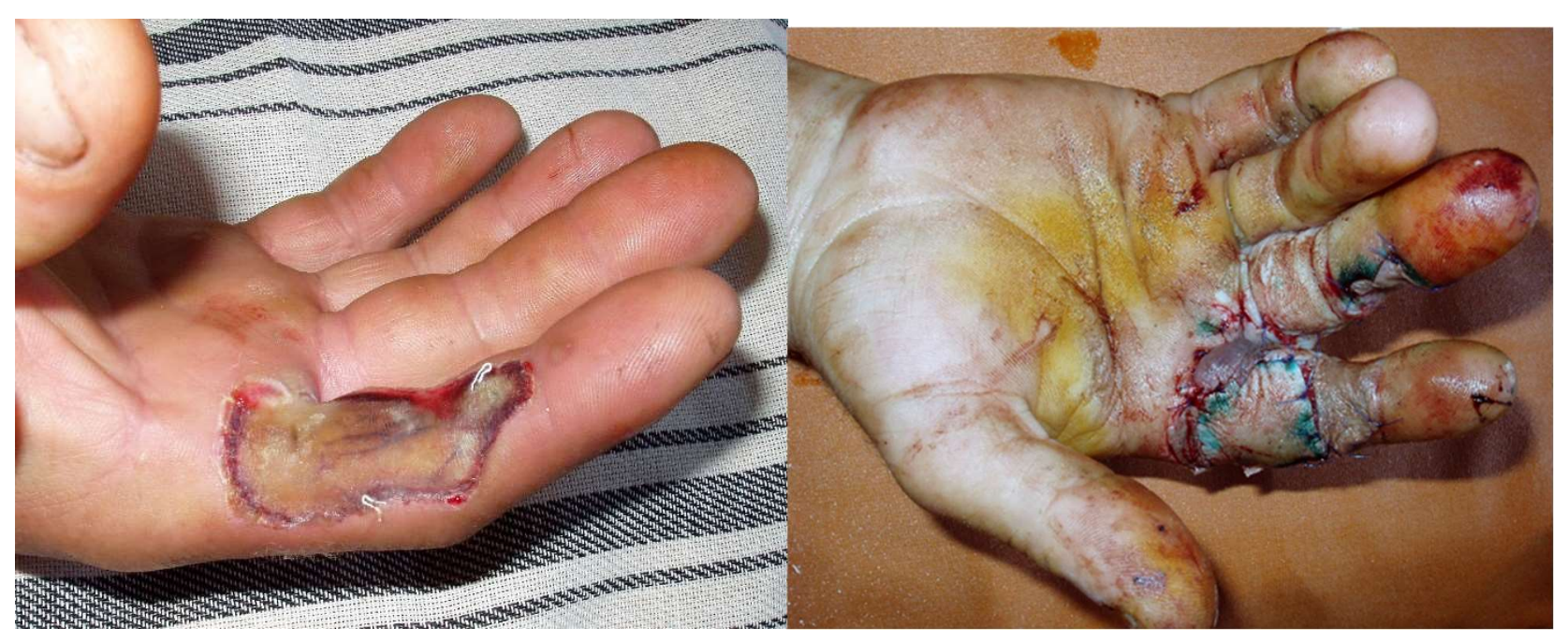

A

Б

Рис. 8. Хворий Ц. (А) щільний некротичний струп на долонній поверхні основної фаланги 2 пальця після низьковольтної електротравми; (Б) пластика дефекту після висічення нейросудинним острівцнвим гетеродигітальним клаптем.

\subsubsection{6. Клапоть на 1 тильній метакарпальній артерії (1 TMА)}

У 1987 році Earley M.J. та Milner R.H. вперше описали тильні клапті кисті засновані на 1 та 2 метакарпальних артеріях $[385,386]$

Клапоть на 1 ТМА базується на однойменній судині - гілці променевої артерії. Використовується клапоть для пластики дефектів 1 пальця, 1 міжпальцевого проміжку та тилу кисті. При включенні у клапоть поверхневої гілки променевого нерва можливо відновлення чутливості 1 пальця (рис. 9). 
TRADITIONAL MEDICINE AND PHARMACOLOGY. ACHIEVEMENTS, INNOVATIONS, AND ALTERNATIVES

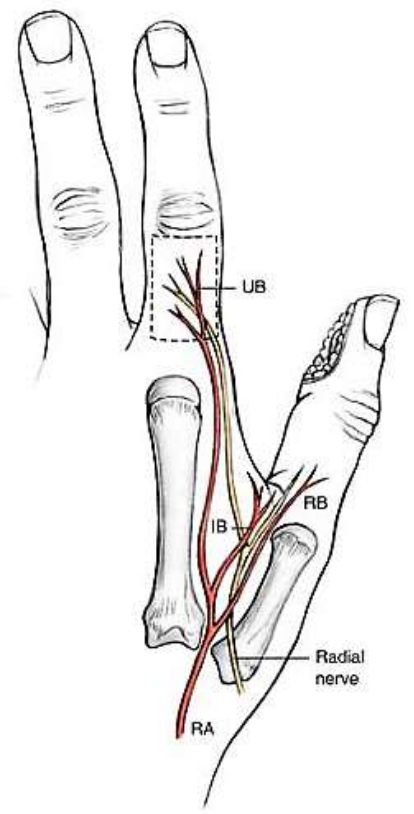

Рис. 9. Судинна основа клаптя на 1 тильній метакарпальній артерії

Формування клаптя здійснюється $з$ тканин тильно-променевої поверхні проксимальної фаланги 2 пальця 3 можливим подовженням на променеву поверхню п’ястко-фалангового суглоба (ПФС) та 2 п’ясткової кістки. Клапоть виділяється від периферії до центру. Після необхідної розмітки розсікається шкіра на всі товщу і піднімається разом з фасцією 1 міжосьового м’язу до окістя для включення судинної ніжки, що проходить у фасціальній кишені. Точка ротації клаптя знаходиться в проекції 1 міжпальцевого проміжку у місці відгалуження 1 ТМА від променевої артерії. Після виділення клапоть повертають на необхідний кут і підшивають до ранового дефекту. Донорська ділянка закривається вільним трансплантатом.

Клінічний приклад. Хворий Р., 42 роки поступив 3 дефектом долонної поверхні дистальної фаланги 1 пальця внаслідок низьковольтного ураження електричним струмом. На 2 добу здійснено видалення некрозу на долонній поверхні нігтьової фаланги 1 пальця. Для відновлення м’яких тканин та чутливості сформовано на променевій поверхні основної фаланги 2 пальця шкірний клапоть 3 включенням 1 ТМА. Крізь утворене ложе, клапоть підведено до дефекту i підшито до країв рани. Післяопераційний період проходив без ускладнень (рис. 10). 


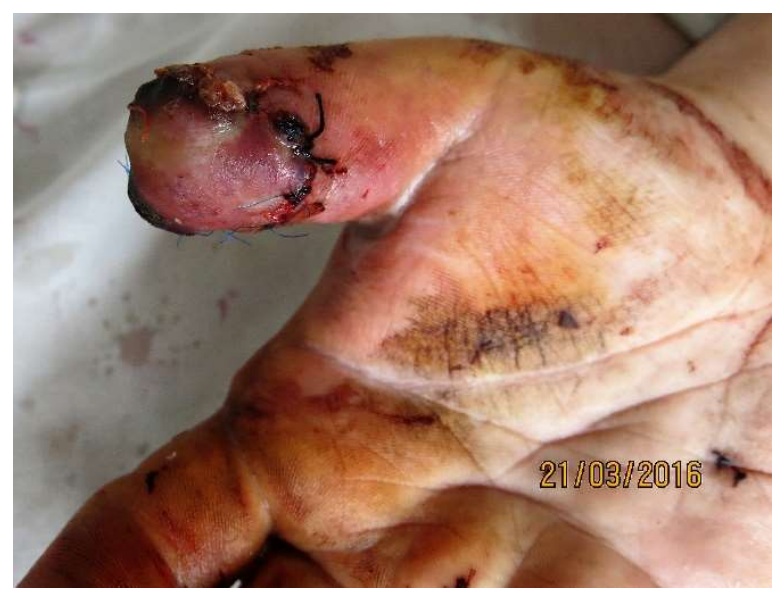

A

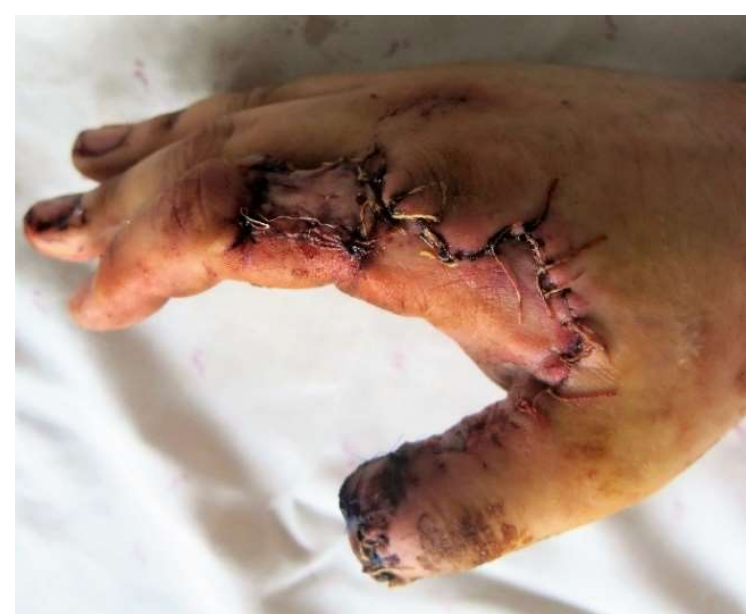

Б

Рис. 10. (А) пластика дефекту нігтьової фаланги нейроваскулярним клаптем на 1 TMА; (Б) донорська ділянка закрита вільним трансплантатом, а місце судинної ніжки первинно ушито.

\subsubsection{7. Клапоть на 2 тильній метакарпальній артерії (2 ТМА)}

Клапоть на 2 ТМА використовується для великих дефектів тильної поверхні пальці [387, 388].

Клапоть формується на дистальній ніжці. Точка ії ротації знаходиться у місці відходження перфоранта у 2 міжпальцевому проміжку. Межі клаптя сягають проксимально від ретінакулума розгиначів пальців до ПФС дистально. Зовні кордони обмежуються метакарпальними сусідніми проміжками. Підняття клаптя здійснюється з проксимальної його частини над паратеноном сухожиль розгиначів з виділенням 2 ТМА, яка лежить в дистальній частині на міжкісткових м'язах. Після формування клапоть розвертається під необхідним кутом навколо точки ротації і фіксується до ранового дефекту. Донорська ділянки первинно ушивається чи закривається вільним трансплантатом.

Клінічний приклад. Хвора Б. 10 років поступила 3 дефектом тканин ліктьової поверхні основної фаланги та ПМФС після низьковольтного електроураження. На 2 добу після висічення некрозу виявлено порушення цілісності капсули ПМФС з оголенням кісток, що утворюють суглоб. В ділянці 2 метакарпального простору сформований шкірний клапоть 3 включенням 2 
TRADITIONAL MEDICINE AND PHARMACOLOGY. ACHIEVEMENTS, INNOVATIONS, AND ALTERNATIVES

TMА. Крізь утворене ложе, клапоть підведено до дефекту і підшито до країв рани. Післяопераційний період проходив без ускладнень (рис. 11).

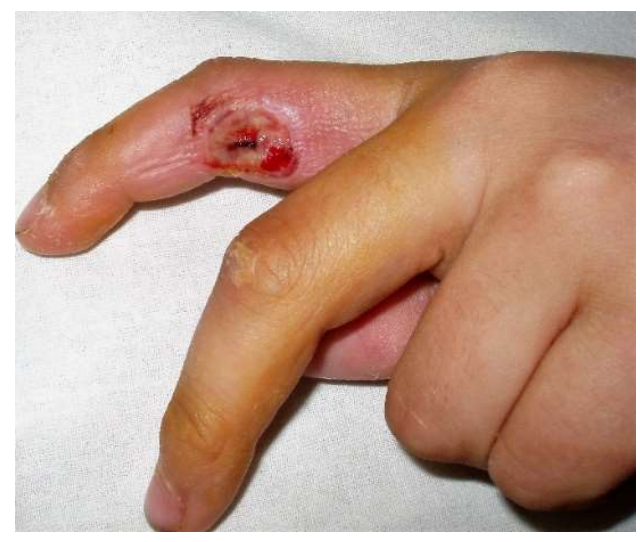

A

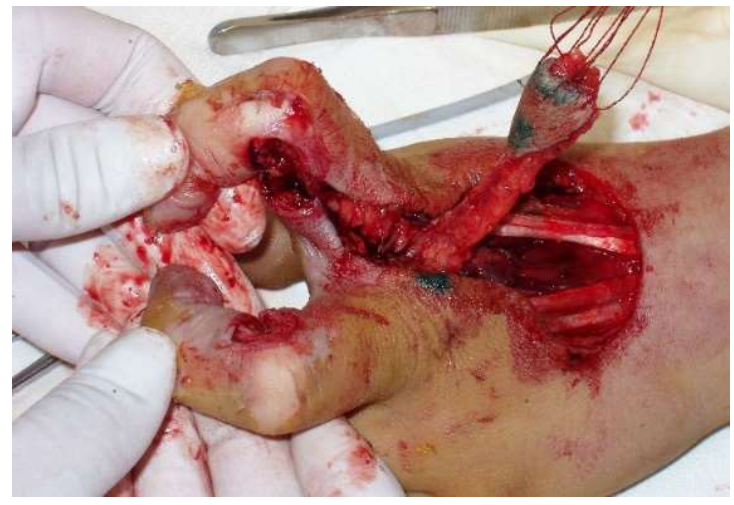

Б

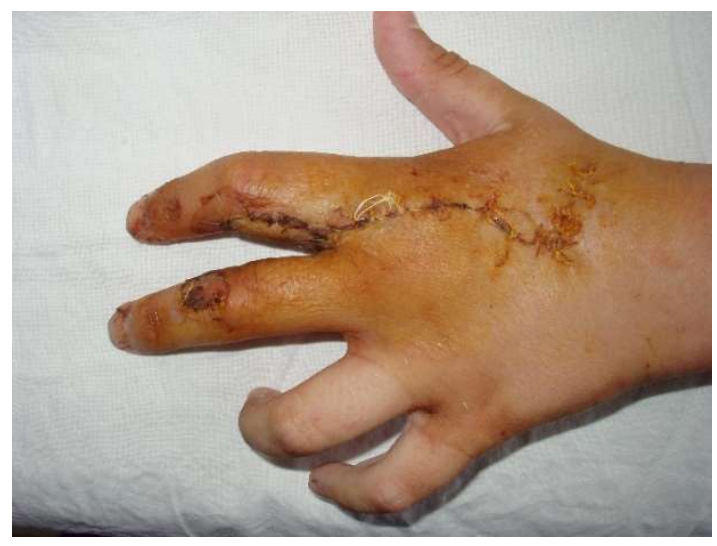

B

Рис. 11. (А) дефект тканин ліктьової поверхні основної фаланги та ПМФС; (Б) формування клаптя на 2 ТМА; (В) результат пластики дефекту клаптем на 2 TMA.

Клінічний приклад. Хворий К. 40 років поступив 3 дефектом тканин 1 та 2 міжпальцевих проміжків після низьковольтного електроураження. На 3 добу після висічення некрозу виявлено оголення глибоких утворень. В ділянці 2 метакарпального простору сформований шкірний клапоть 3 включенням 1 ТМА. Крізь утворене ложе, клапоть підведено до дефекту у 1 міжпальцевий проміжок та частково долонну поверхню і підшито до країв рани. На тилі кисті сформований клапоть 3 включенням 2 ТМА, яким закрито 2 міжпальцевий проміжок. Післяопераційний період проходив без ускладнень (рис. 12). 
TRADITIONAL MEDICINE AND PHARMACOLOGY. ACHIEVEMENTS, INNOVATIONS, AND ALTERNATIVES

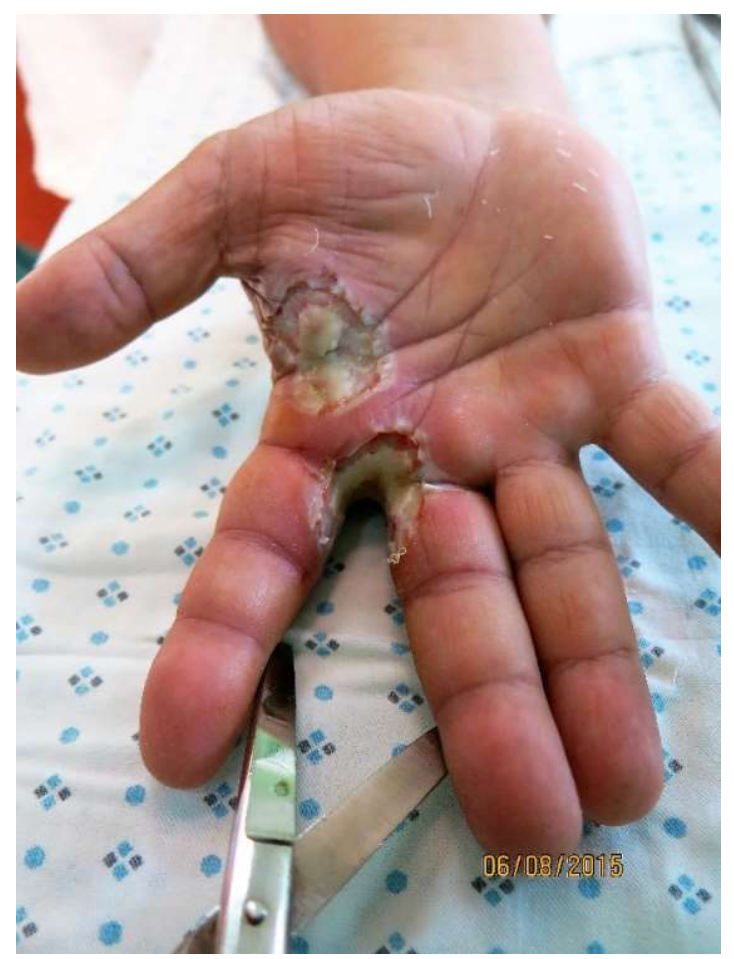

A

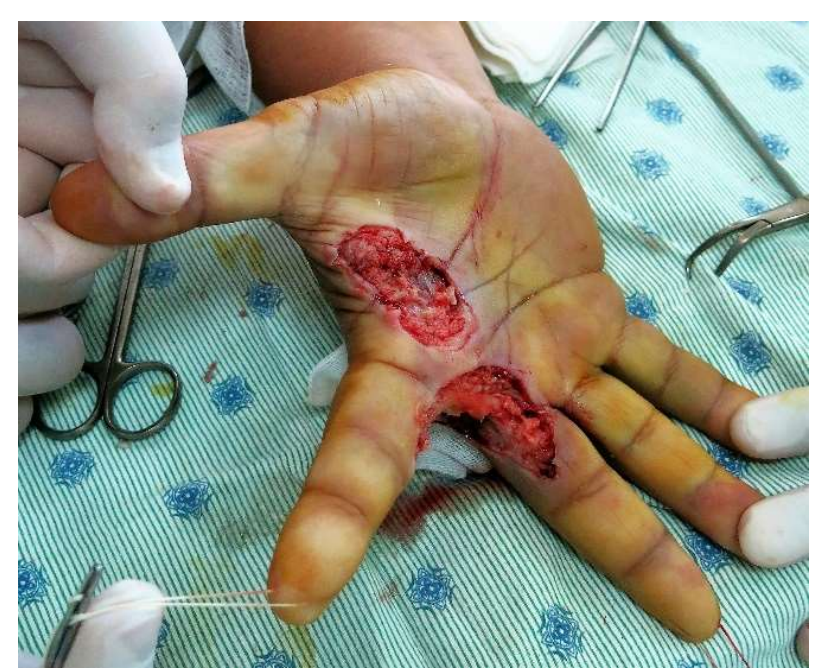

$\mathrm{B}$

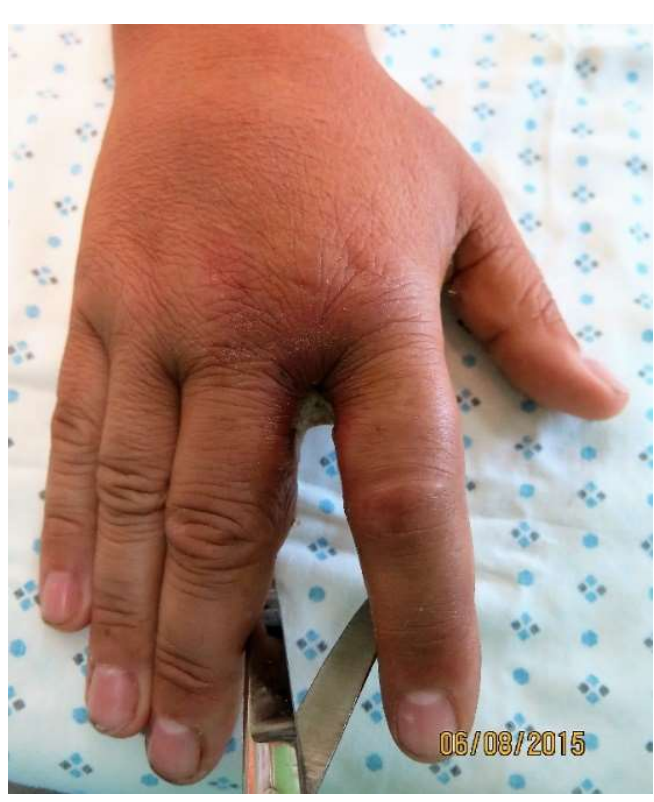

Б

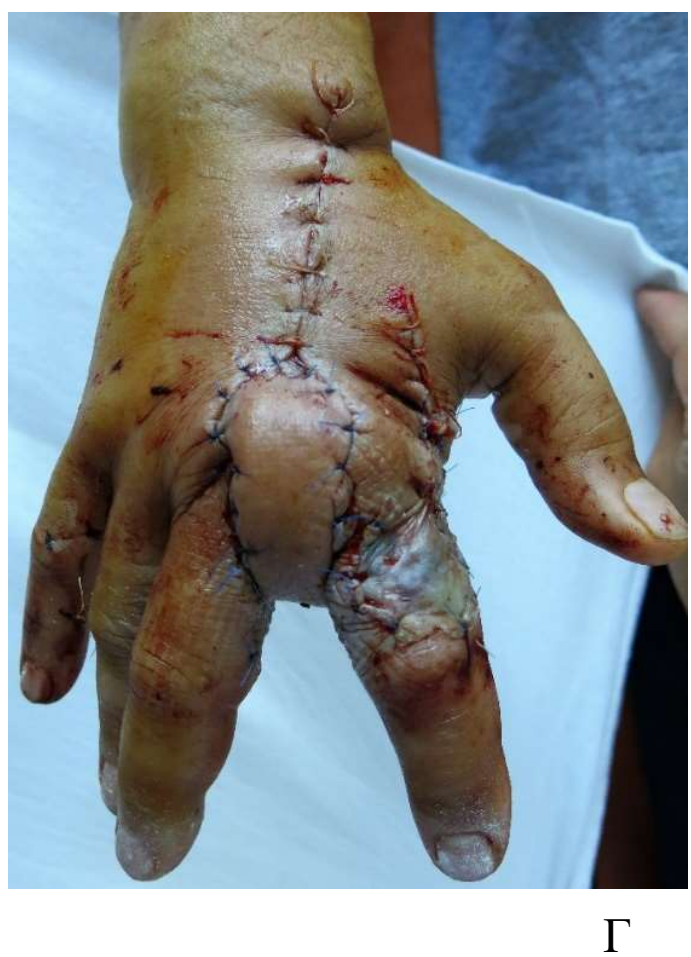



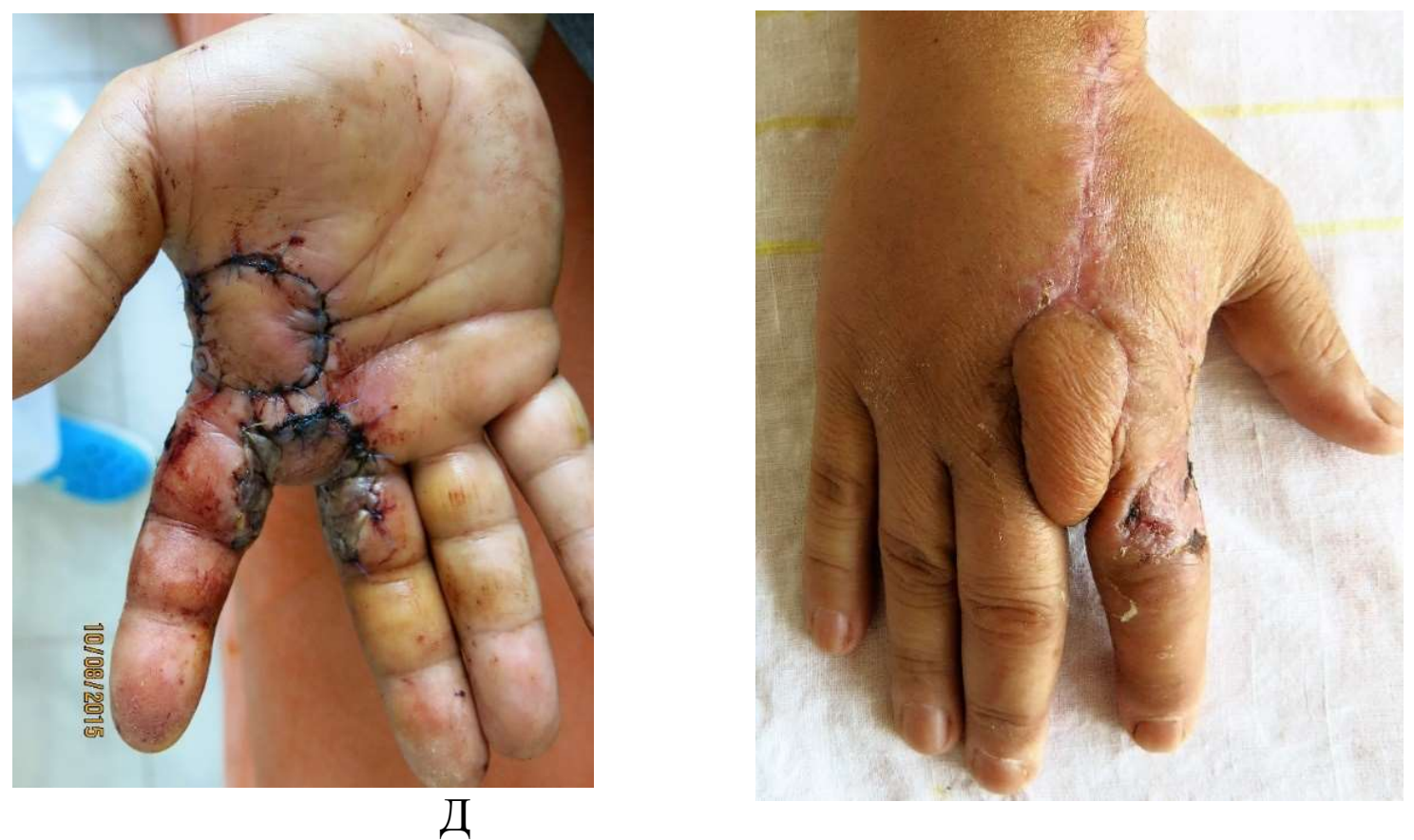

Рис. 12. (А) ураження електричним струмом долонної поверхні кисті та

(Б) 2 міжпальцевого проміжку; (В) висіченні некротичних тканин 3

утворенням панових поверхонь; (Г, Д) пластика дефекту 1 міжпальцевого проміжку клаптем на 2 TMА та дефекту долонної поверхні кисті клаптем на 1 ТМА; (Е) результат лікування через 3 місяці.

\subsubsection{2 Клапті передпліччя}

Кровозабезпечення тканин передпліччя здійснюється променевими та ліктьовими судинами. На основі цих судин формуються осьові клапті передпліччя, які знайшли широке використання в реконструктивній та пластичній хірургії.

Особливо великі можливості у реконструктивно-відновній хірургії мають клапті з включенням перфорантних судин. Nakajima H. C et al. (1986), Blondeel P.N. et al. (2003), Taylor G.I. et al. (2003) [389-391].

Кровопостачання шкіри забезпечується декількома перфорантними судинами, що походять від променевої та ліктьової артерій. Кожен 3 цих перфорантів має власну судинну територію - перфорасому. Ці перфорасоми пов'язані один з одним як прямими, так і непрямими зв'язуючими судинами. Такі численні, щільні мережі здійснюють додатковий захист від ішемії і 
TRADITIONAL MEDICINE AND PHARMACOLOGY. ACHIEVEMENTS, INNOVATIONS, AND ALTERNATIVES

пояснюють виживання окремих клаптів на основі перфорантів. Ці судинні гілки утворюють фасціальні та підшкірні судинні сплетіння, що мають вирішальну роль у живленні шкіри. При цьому судинні зв'язки дозволяють з’єднуватися між собою сусідні перфорасоми i напрямок кровотоку здійснюється паралельно напрямку потоку перфоранта. Отже, вісь перфорантного клаптя повинна йти паралельні орієнтації живильної судини, що дає можливість збирати великі клапті на основі єдиного домінантного перфоранта.

Таким чином, судинний ланцюг кровопостачання тканин перфорантними судинами дуже складний, а тому і прямі і непрямі судинні гілки відіграють важливу роль у підтримці перфузії клаптів. Це явище дозволяє створювати безліч перфораторних клапанів, які можуть бути адаптовані до реконструкції різних дефектів.

Ці дослідження лягли в основу формування шкірно-фасціальних та шкірно м'язових клаптів з включенням перфорантних судин

Головна перевага таких клаптів полягає в тому, що при втручанні не жертвуються осьові домінантні судини. Однак, виділення таких клаптів потребує прецизійної техніки, а площа закриття досить обмежена.

\subsubsection{1. Променевий реверсний шкірно-фасціальний клапоть} передпліччя

Променевий реверсний шкірно-фасціальний клапоть передпліччя являє собою острівцевий клапоть і живиться за рахунок ретроградного току крові через ліктьову артерію та долонних артеріальних дуг після лігування променевої артерії у проксимальному відділі клаптя. Зворотній кровоток забезпечує високу життєздатність клаптя. Використовується клапоть при глибоких дефектах тканин кисті та передпліччя з ураженням кісток, суглобів та сухожиль [392-394].

Форма та розташування клаптя на внутрішній поверхні передпліччя залежить від величини дефекту i необхідній довжині судинної ніжки. 
TRADITIONAL MEDICINE AND PHARMACOLOGY. ACHIEVEMENTS, INNOVATIONS, AND ALTERNATIVES

Втручання здійснюється під джгутом. Після шаблонної розмітки клаптя та проекції судинного пучка розсікається шкіра на всю товщу разом із власними фасціями прилеглих м’язів. Після прошивання шкірно-фасціального шару i взяття його на шви-трималки здійснюється підняття клаптя від проксимальної краю. Одночасно з відсепаруванням фасцій від м'язів, виділяється міжфасціальна перегородка разом із променевою артерією і веною. Від судин відокремлюють латеральний шкірний нерв передпліччя. Від дистального краю клаптя S-подібним розрізом розсікають м'які тканини над променевим судинним пучком і виділяють його до точки ротації клаптя - шилоподібного відростка де судина переходить на тильну поверхню кисті. Після зняття джгута на проксимальну частину артерії накладають судинну кліпсу. Гарне відновлення кровообігу у клапті свідчить про можливість безпечного пересічення променевого судинного пучка у проксимальному відділі. Від точки ротації до дефекту здійснюється розріз і формування ложа для судинного пучка. Після цього клапоть повертається на місце дефекту, а судинний пучок вкладається у сформований канал. Клапоть підшивається до країв рани, а донорська ділянка закривається вільним трансплантатом (рис. 13).

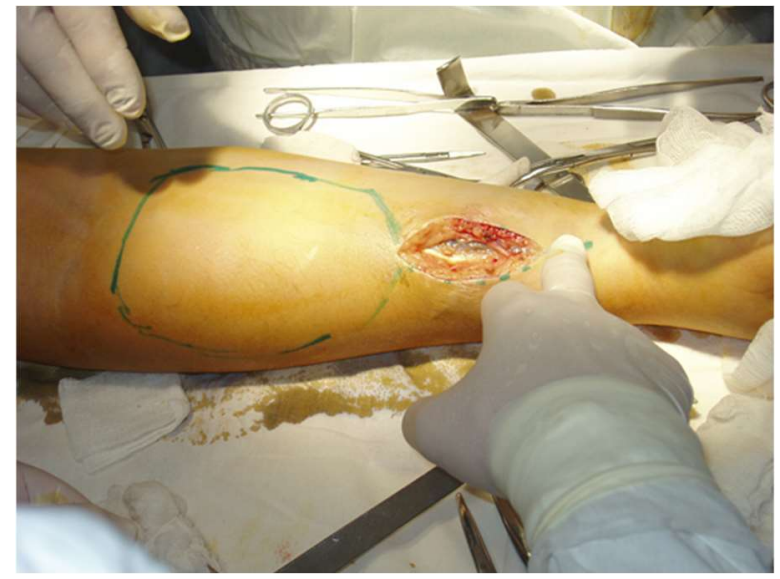

A

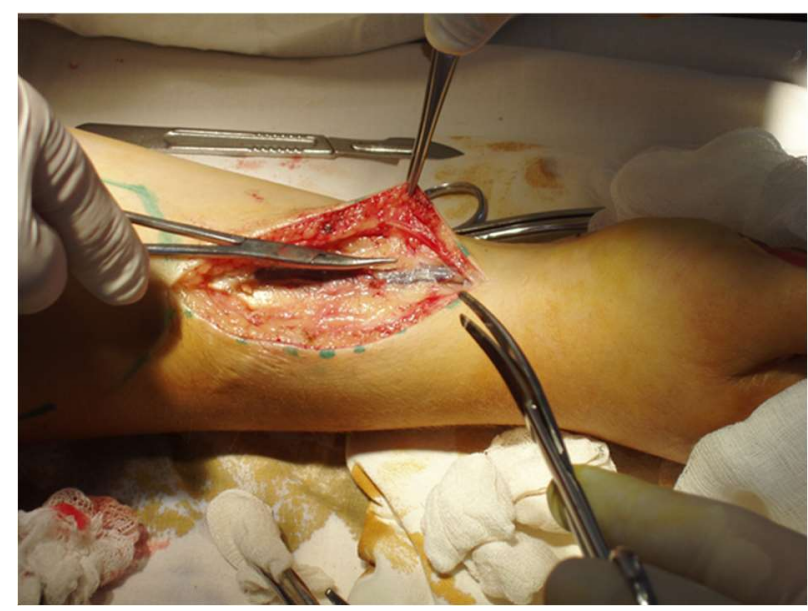

Б 
TRADITIONAL MEDICINE AND PHARMACOLOGY. ACHIEVEMENTS, INNOVATIONS, AND ALTERNATIVES

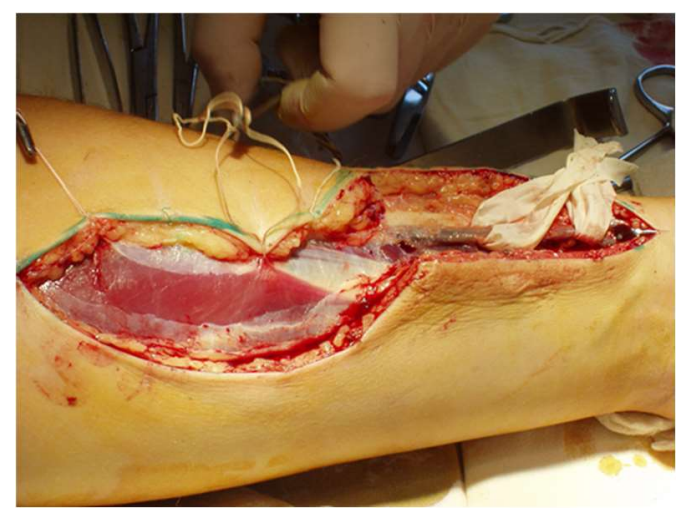

B

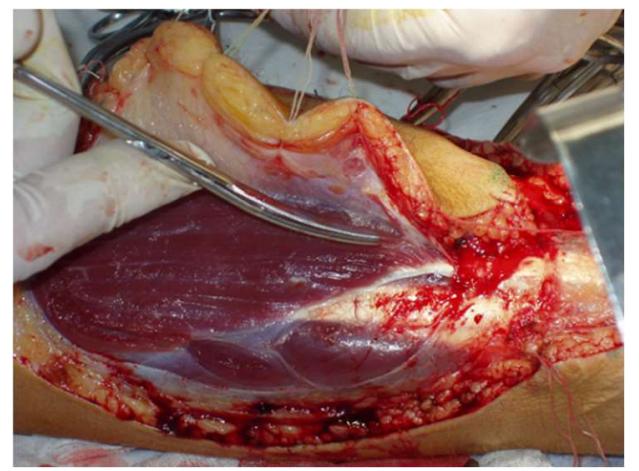

Д

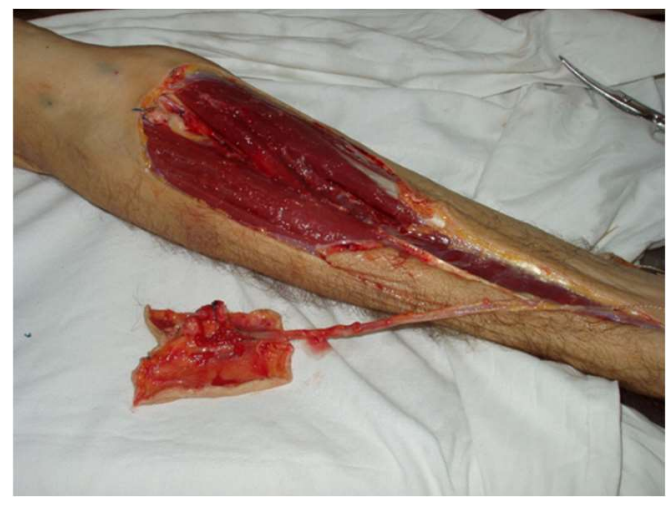

Ж

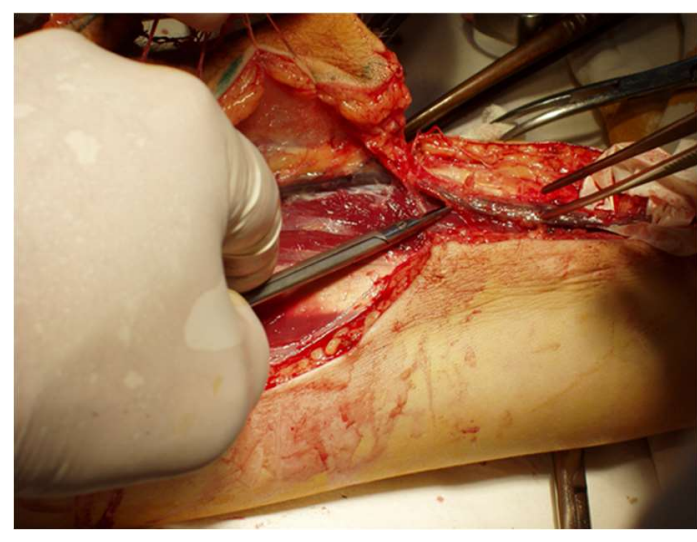

$\Gamma$

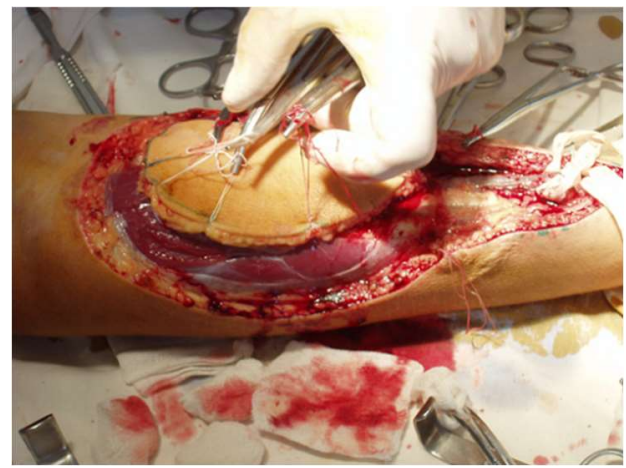

$\mathrm{E}$

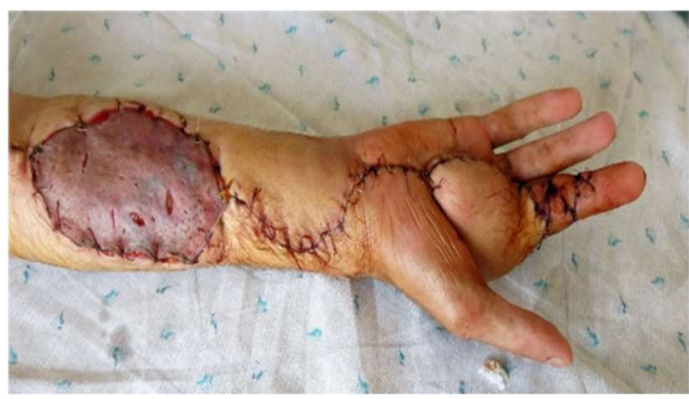

3

Рис. 13. Формування променевого реверсного клаптя передпліччя (коментарі по тексту)

Клінічний приклад. Хворий М., 35 років, отримав контактний опік 3 ступеня долонної поверхні правої кисті. Після видалення некрозу оголились апоневротично-сухожилкові утворення. Сформованим реверсним променевим клаптем здійснено закриття ранового дефекту (рис. 14). 
TRADITIONAL MEDICINE AND PHARMACOLOGY. ACHIEVEMENTS, INNOVATIONS, AND ALTERNATIVES

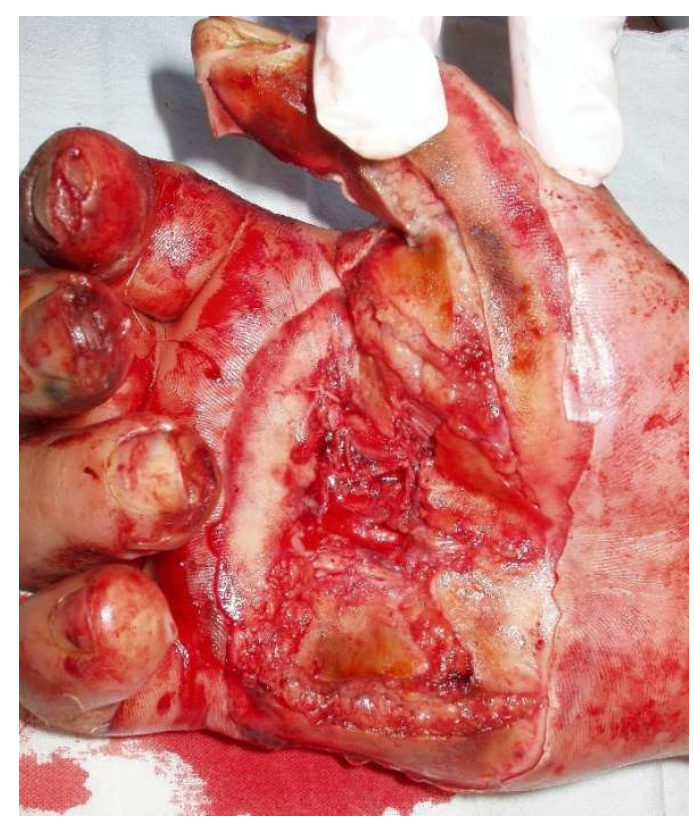

A

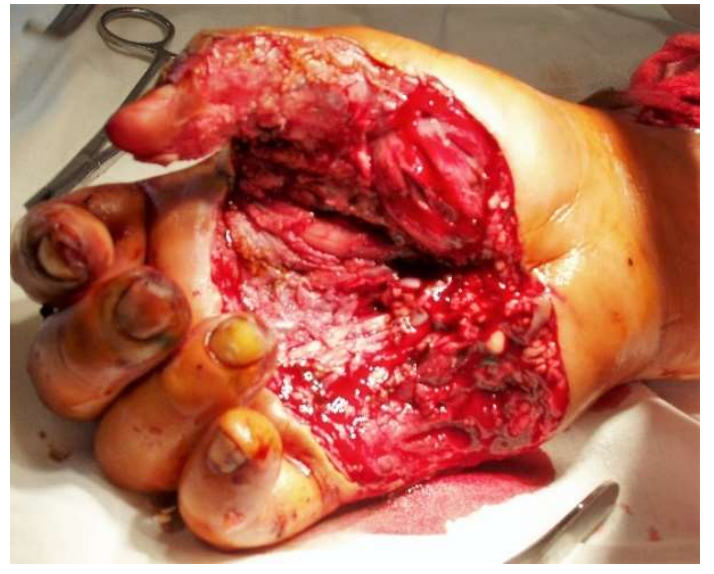

Б

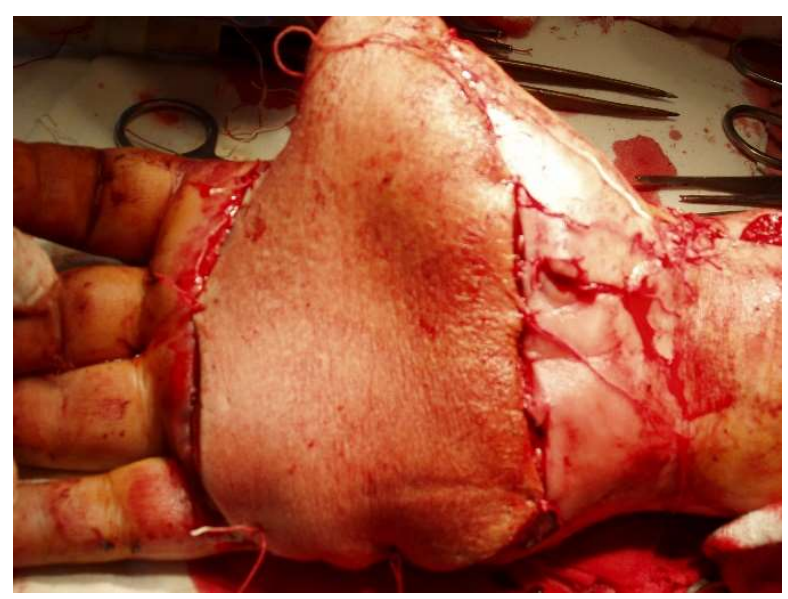

B

Рис. 14 (А) некроз тканин долонної поверхні кисті після контактного опіку; (Б) видалення некротичних тканин; (В) пластика ранової поверхні кисті променевим реверсним клаптем передпліччя.

\subsubsection{2. Перфорантні клапті променевої артерії}

Зворотний кровоток променевого реверсного клаптя передпліччя має великі переваги щодо його використання для відновлення дефектів кисті. Однак, виключення великої судини 3 кровообігу ставить під загрозу життєздатність кінцівки, а деформація донорської ділянки виключає гарний косметичний ефект. Для зменшення таких негативних впливів Saint-Cyr

М. із співавторами у 2010 році детально описав анатомічні особливості і 
TRADITIONAL MEDICINE AND PHARMACOLOGY. ACHIEVEMENTS, INNOVATIONS, AND ALTERNATIVES

клінічне застосування дистального та проксимального перфорантних клаптів променевої артерії [395].

Дистальний перфорантний клапоть променевої артерії застосовується для пластики дефектів кисті, променево-зап'ясткового суглоба та передпліччя [396, 397].

Живлення клаптя здійснюється декількома септокутанними перфорантними судинами які виходять від променевої артерії на відстані 1,01,5 см від шилоподібного відростка променевої кістки і визначають точку ротації клаптя. Після необхідної шаблонної розмітки клаптя на променевій поверхні передпліччя в дистальній та середній його третинах розсікаються м'які тканини разом з глибокою фасцією. Піднімається клапоть зі своєї проксимальної частини разом 3 м'язовими фасціями для попередження пошкодження судинних зв'язків до виходу перфорантних судин з міжм'язової перегородки між сухожиль променевого згинача кисті та поверхневого згинача пальців. Після формування клапоть розвертається навколо живлячої ніжки на необхідний кут і підшивається до країв дефекту (рис. 15). Донорська рана частково ушивається та закривається вільним трансплантатом.

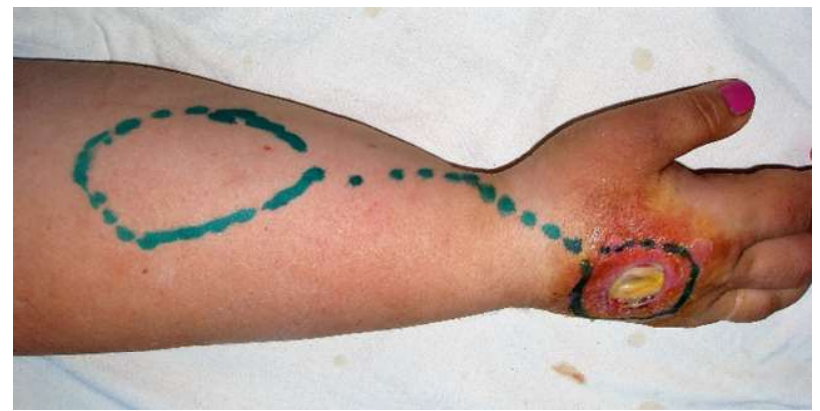

A

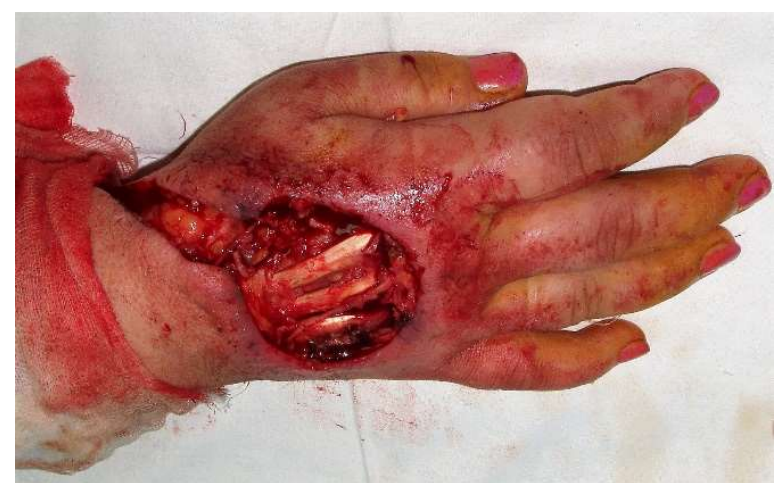

Б 
TRADITIONAL MEDICINE AND PHARMACOLOGY. ACHIEVEMENTS, INNOVATIONS, AND ALTERNATIVES

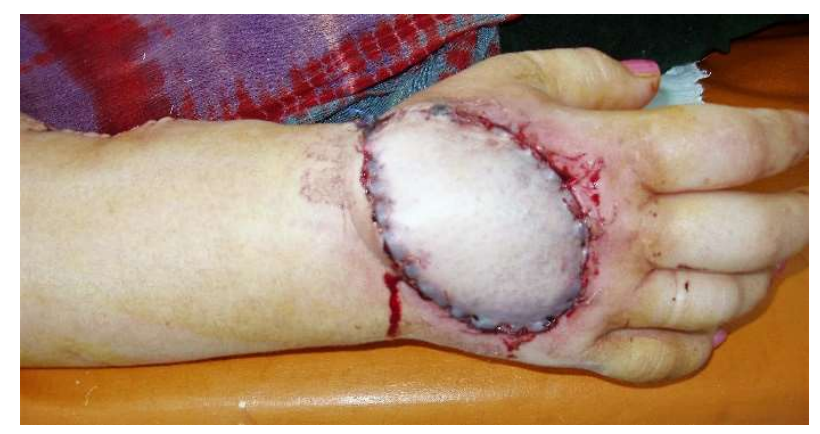

B

Рис. 15. (А) дефект тильної поверхні кисті, розмітка дистального перфорантного клаптя променевої артерії; (Б) дефект тилу правої кисті після видалення некротичних тканин; (В) пластика дефекту дистальним перфорантним клаптем променевої артерії.

Проксимальний перфорантний клапоть променевої артерії формується на основі перфорантних судин в проксимальній частині променевої артерії [398, 399]. Застосовується клапоть для пластики дефектів передпліччя та ділянки ліктьового суглоба. Після маркування клаптя в прокимальній та середній третинах променевої поверхні передпліччя розсікається шкіра та підлеглі тканини разом з глибокою фасцією. Виділяється клапоть з дистальних відділів до місця виходу перфорантних судин крізь міжм'язову перегородку між плечопроменевим м'язом та променевим згиначем кисті. Точка виходу судин знаходиться на межі проксимальної та середньої третини передпліччя. Після переміщення клаптя на рановий дефект донорська ділянка закривається вільним трансплантатом.

\subsubsection{3. Перфорантний клапоть ліктьової артерії}

Перше анатомічне описання та клінічне застосування клаптя здійснили Becker C., Gilbert A. у 1988 році [400]. Клапоть застосовують для пластики дефектів кисті та променево-зап'ясткового суглоба. Живлення клаптя здійснюється тильною перфорантною судиною, що відходить від ліктьової артерії на відстані 2-4 см від горохоподібної кістки. Судина прямує на тил 
TRADITIONAL MEDICINE AND PHARMACOLOGY. ACHIEVEMENTS, INNOVATIONS, AND ALTERNATIVES

ліктьової поверхні передпліччя, пронизуючи фасцію між сухожиллям ліктьового згинача кисті та окістям ліктьової кістки [401, 402].

Після маркування клаптя в дистальній третині ліктьової поверхні передпліччя розсікається шкіра та підлеглі тканини разом з глибокою фасцією. Виділяється клапоть з проксимального відділу до місця виходу перфорантної судини крізь фасцію. Після переміщення клаптя на рановий дефект донорська ділянка ушивається чи закривається вільним трансплантатом (рис.16).
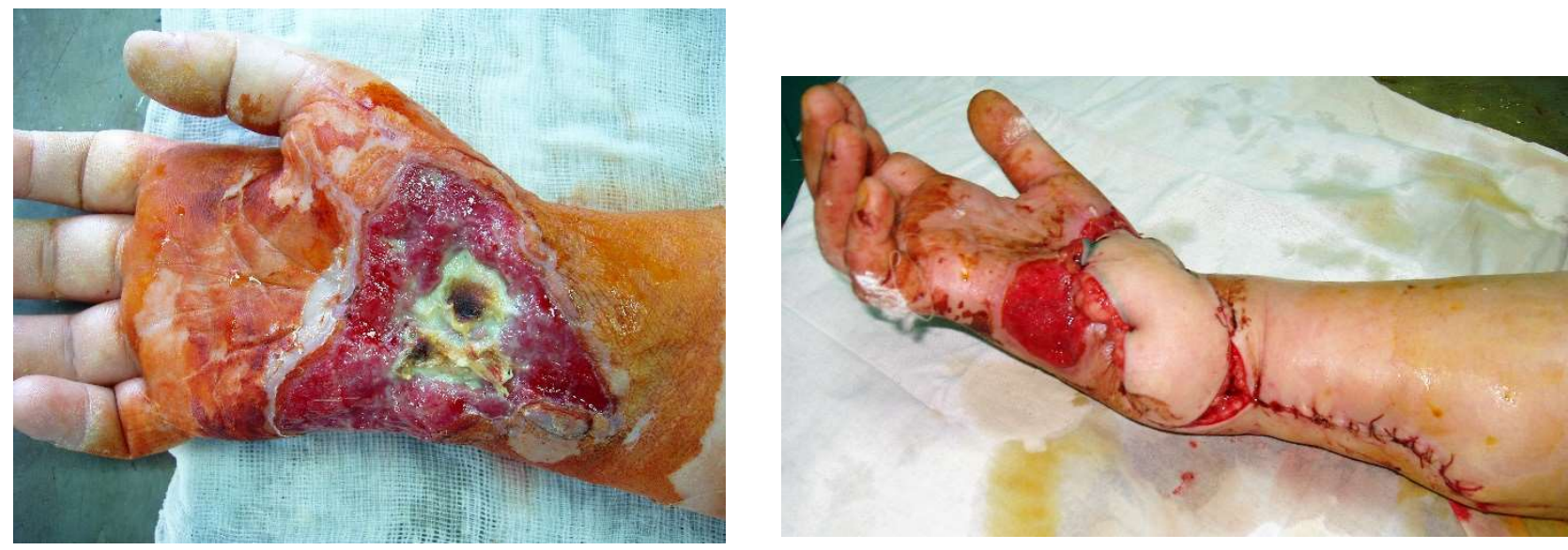

A

Б

Рис. 16. (А) контактний опік долонної поверхні кисті та променевозап’ясткового суглоба; (Б) пластика дефекту перфорантним клаптем ліктьвої артерії.

\subsubsection{4. Реверсний тильний клапоть задньої міжкісткової артерії}

Вперше анатомічне обгрунтування та клінічне застосування тильного клаптя задньої міжкісткової артерії здійснили Zancolli E.A. та Angrigiani C. у 1988 році [403].

Шкіра тилу передпліччя живиться декількома шкірними гілками задньої міжкісткової артерії. На основі дистального анастомозу між передніми і задніми міжкістковими артеріями можливе формування острівцевих клаптів. Такі клапті застосовуються для пластики дефектів м'яких тканин тильної поверхні кисті та променево-зап’ясткового суглоба. 
TRADITIONAL MEDICINE AND PHARMACOLOGY. ACHIEVEMENTS, INNOVATIONS, AND ALTERNATIVES

Живлення клаптя здійснюється за рахунок зворотнього току крові через задню міжкісткову артерію та перфорантний анастомоз задньої гілки передньої міжкісткової артерії в дистальній частині передпліччя після лігування судини в проксимальній частині [404, 407].

Розташовується клапоть на тильній поверхні передпліччя у середній та верхній його третинах в залежності від розміру дефекту (рис. 17).

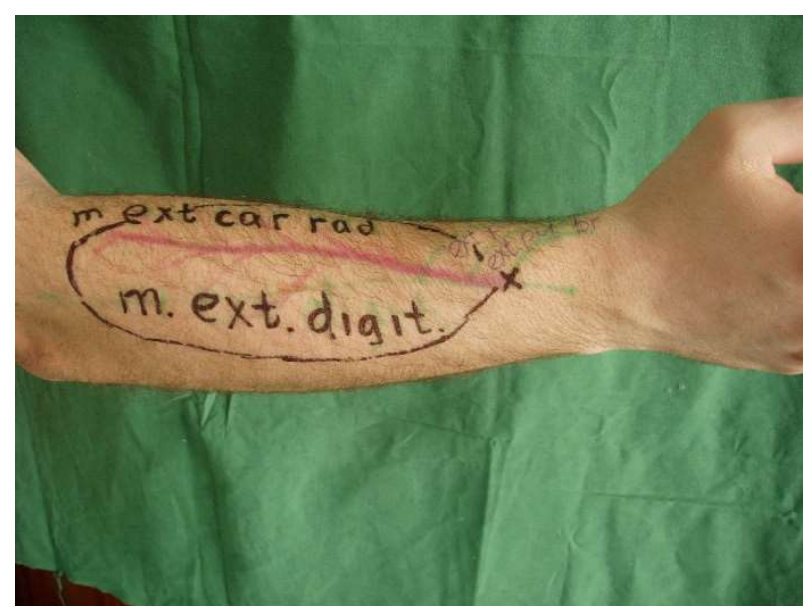

Рис. 17. Розмітка реверсного тильного клаптя задньої міжкісткової артерії

Після маркування клаптя розсікається шкіра разом з власними фасціями прилеглих м'язів і в середній частині передпліччя здійснюється доступ до судинної ніжки. У клапоть разом 3 м'язовими фасціями включається міжм'язова перегородка між ліктьвим розгиначем зап'яска та розгиначем 5 пальця в якій знаходиться задня міжкісткова артерія. Судина відокремлюється від глибокої гілки променевого нерва і виділяється до точки їі ротації яка знаходиться на 1-4 см вище шилоподібного відростка ліктьової кістки в зоні виходу перфорантної артерії від задньої гілки передньої міжкісткової артерії. Формується ложе для судинного пучка і клапоть фіксується до ранової поверхні. Донорська рана може бути ушита первинно (рис. 18). 


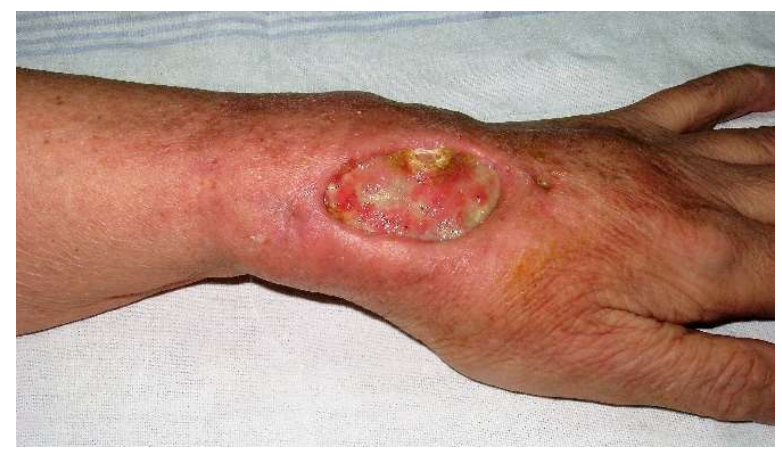

A

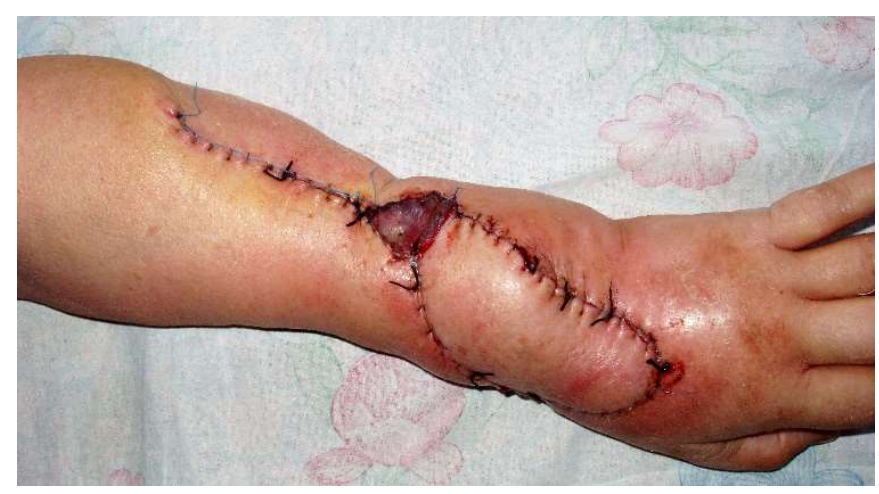

Б

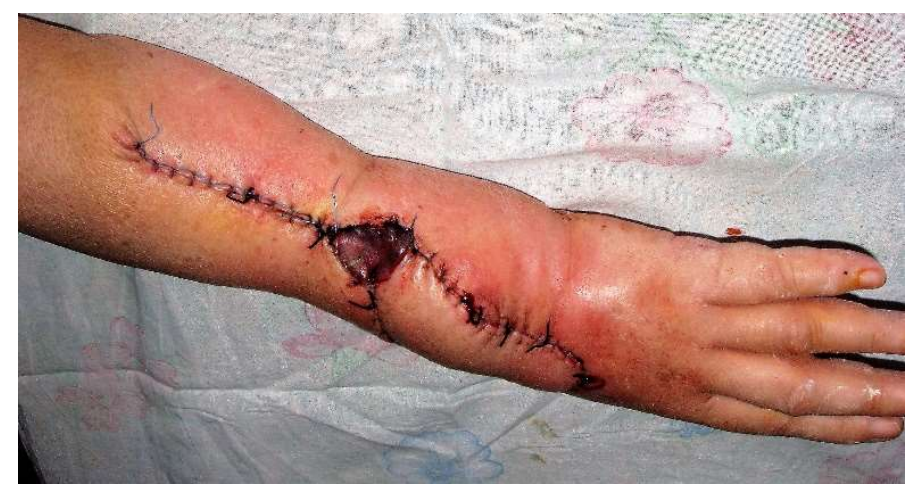

C

Рис. 18. (А) дефект тканин тилу кисті та променево-зап'ясткового суглоба; (Б, С) пластика дистальним реверсним тильним клаптем задньої міжкісткової артерії.

Клінічний приклад. Хворий С. 65 років у 1987 році отримав травму при протоновому опроміненні кінцівок. У гострий період променевої хвороби отримував загальну терапію. Неодноразово отримував хірургічне лікування у спеціалізованих стаціонарах 3 приводу променевих виразок кінцівок. В теперішній час права верхня кінцівка атрофічна. Тонус м’язів зменшений, шкірні покриви бліді. На ліктьовій поверхні передпліччя від шилоподібного виростка ліктьової кістки і вище на 8 см дефект шкірних покривів з оголенням фрагменту ліктьової кістки. Краї рани підриті, атрофічні, бліді. 3 рани відмічаються гнійно-серозні виділення. Вирішено здійснити пластику дефекту тильним клаптем передпліччя на задній міжкісткові артерії, а для закриття донорської ділянки використати розтягутий клапоть внутрішньо-променевої поверхні верхньої третини передпліччя. На першому етапі імплантовано тканинний розширювач на внутрішньо-променеву поверхню передпліччя i 
TRADITIONAL MEDICINE AND PHARMACOLOGY. ACHIEVEMENTS, INNOVATIONS, AND ALTERNATIVES

проведено розтягування клаптя. На другому етапі після маркування клаптя та зони видалення, здійснено висічення гнійно-некротичних тканин дефекту та тангенціальна резекція дистального відділу ліктьової кістки. На тильній поверхні проксимального відділу передпліччя сформовано шкірнофасціальний клапоть на задній міжкістковій артерії, який переміщений на місце дефекту ліктьової поверхні, що утворився. Після видалення розширювача сформований розтягнутий клапоть і закрито дефект донорської зони. У післяопераційному періоді спостерігалося порушення венозного відтоку, які були усунені з використанням герудотерапії. У подальшому клапоть первинно прижив. Хворий спостерігався протягом 6 років. Рецидиву променевої трофічної виразки не спостерігалося (рис.19).

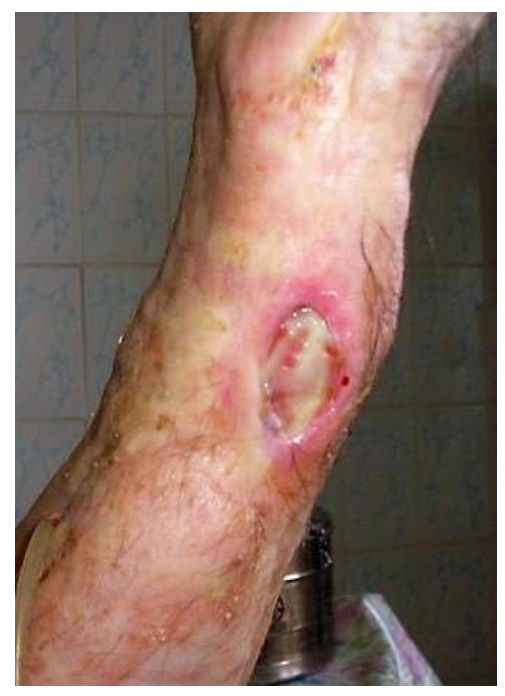

A

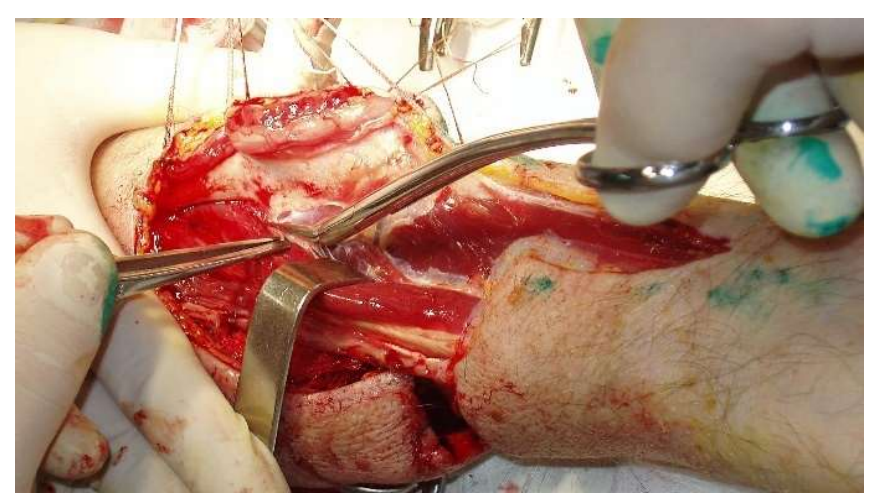

$\mathrm{B}$

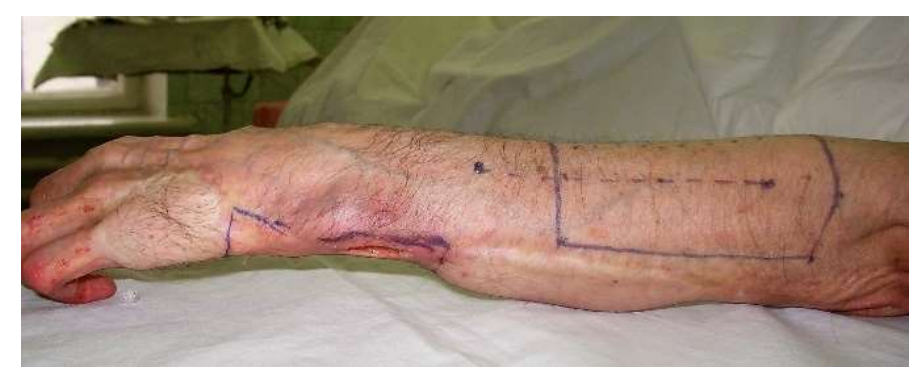

Б

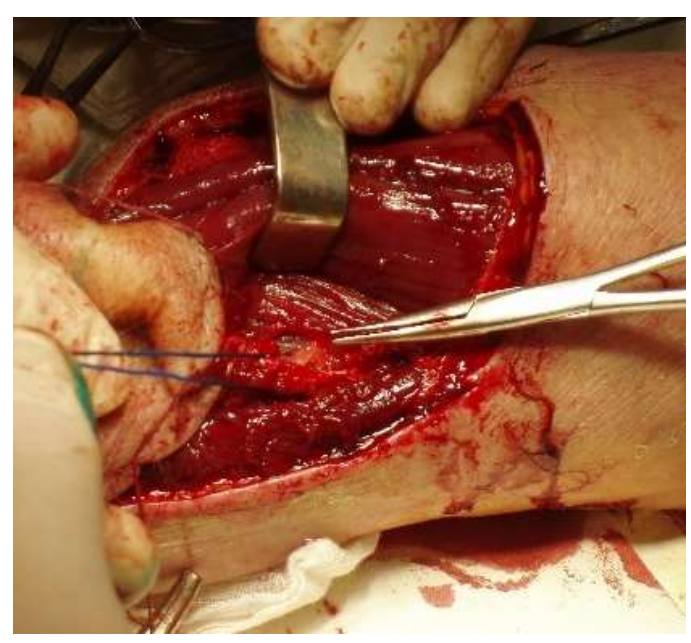

$\Gamma$ 


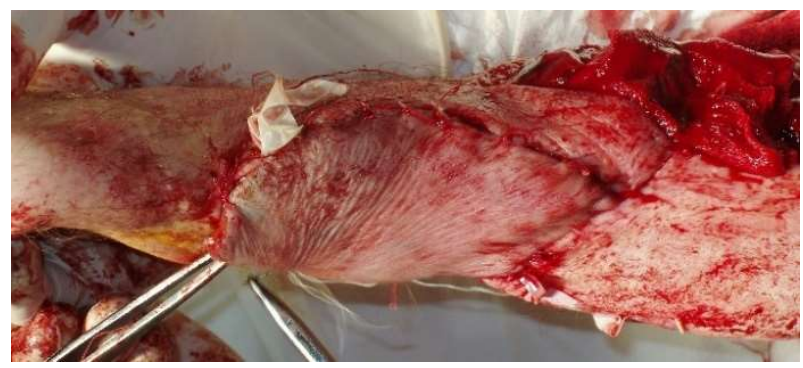

Д

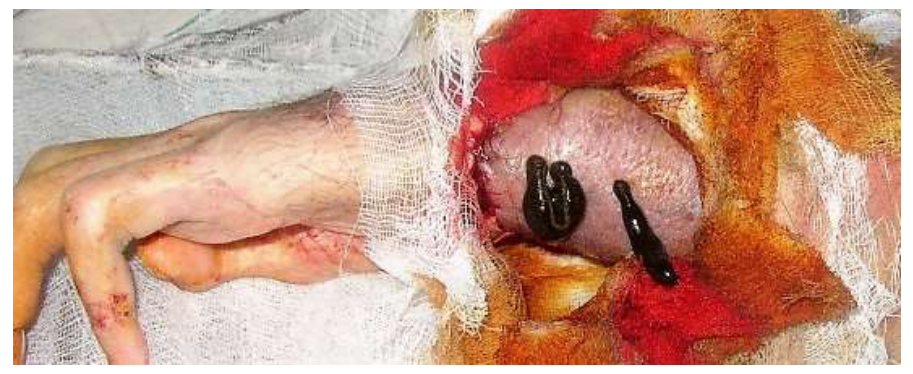

Ж

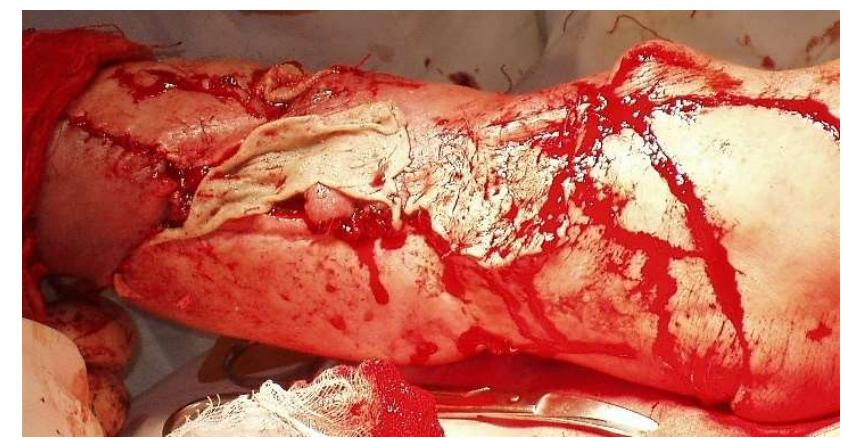

$\mathrm{E}$

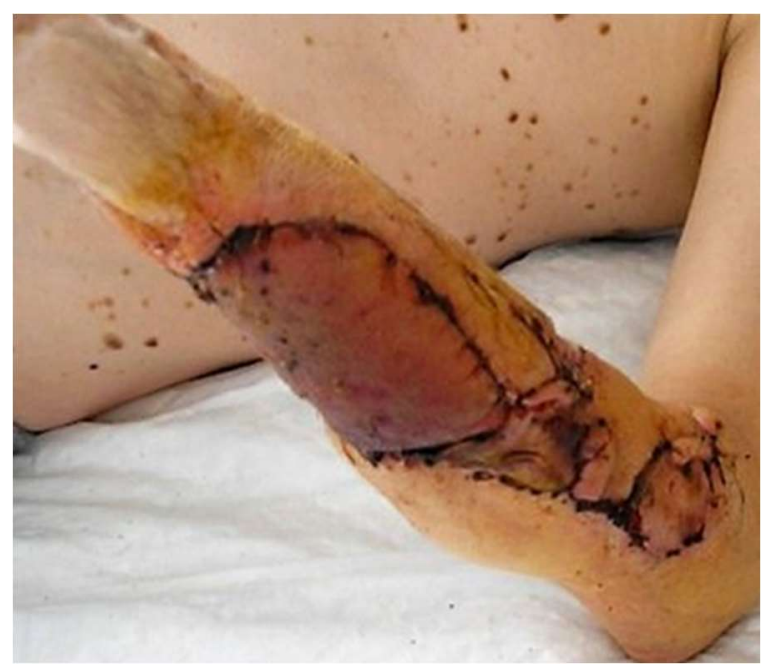

3

Рис. 19. (А) променева виразка нижньої третини передпліччя 3 частковим некрозом ліктьової кістки; (Б) маркування клаптя та ділянки висічення; $(\mathrm{B}, \Gamma)$ формування тильного клаптя передпліччя на задній міжкістковій артерії (виділення живлячих судин); (Д) пластика дефекту клаптем на задній гілці міжкісткової артерії; (Е) закриття донорської ділянки частковим ушиванням прилеглими тканинами передпліччя і вільною пластикою; (Ж) застосування гірудотерапії; (3) повне приживлення клаптя.

\subsubsection{4. Зовнішній подовжений клапоть плеча та передпліччя}

Живлення зовнішньої поверхні дистальної третини плеча, ліктьового суглоба та проксимальної третини передпліччя здійснюється за рахунок 4 5 перфорантних гілок від задньої гілки променевої колатеральної артерії (ЗПКА), яка проходить у латеральній міжм'язовій перетинці плеча, потім 
TRADITIONAL MEDICINE AND PHARMACOLOGY. ACHIEVEMENTS, INNOVATIONS, AND ALTERNATIVES

судина впадає у судинні сплетіння м'яких тканин ділянок зовнішнього надвиростка плеча та ліктьового відростка. У формуванні сплетіння бере також участь зворотна променева артерія (ЗПА) з басейну променевої артерії, яка живить проксимальні відділи передпліччя [408-410].

\section{Техніка операції}

Перед початком формування клаптя проводять розмітку операційного поля, для чого окреслюють лінію проекції латеральної між м'язової перетинки, в якій проходить колатеральна променева артерія. Лінія проекції артерії простягається від акроміального відростка ключиці до латерального виростка плечової кістки. Намічають межі клаптя з центром на лінії проекції. Розріз шкіри та фасції довжиною починають по зовнішній поверхні дистального відділу плеча над плечо-променевим м’язом і далі по передньозовнішньому краю ліктьової ямки 3 переходом на верхню третину передпліччя. Шляхом прецизійної дисекції виділяють латеральну міжм’язову перетинку, в якій проходить ЗПКА із супутніми венами, а також задній шкірний нерв передпліччя. Під час виділення добре візуалізуються судини, які відходять від ЗПКА та розгалужуються у власній фасції. Разом із судинами виділяють задній шкірний нерв передпліччя, який також включають у клапоть. Ідентифікують та включають в клапоть у ділянці плеча ЗПКА разом з 4 - 5 перфорантними гілками, а також гілки ЗПА в ділянці передпліччя. У тканини також включають судинні сплетіння м’яких тканин ділянок зовнішнього надвиростка плеча та ліктьового відростка (рис. 20). 
TRADITIONAL MEDICINE AND PHARMACOLOGY. ACHIEVEMENTS, INNOVATIONS, AND ALTERNATIVES

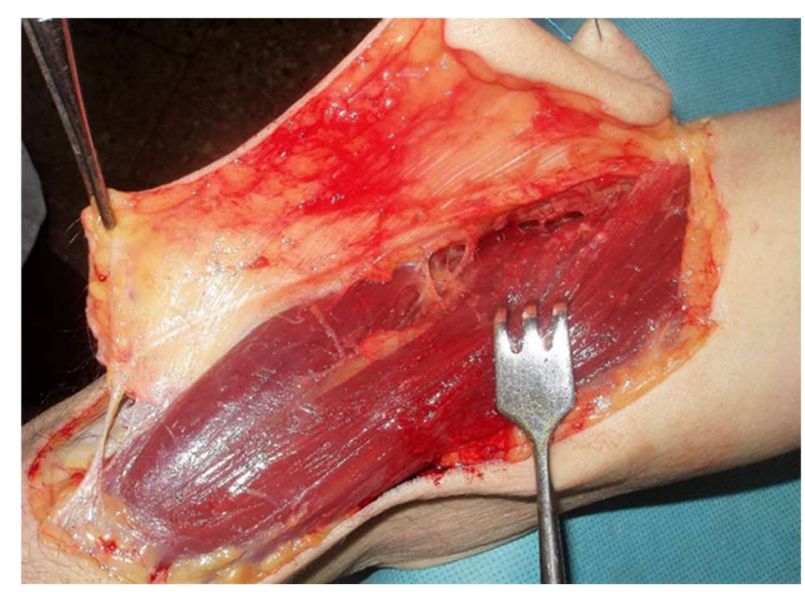

Рис. 20. Етап формування зовнішнього подовженого клаптя плеча та передпліччя, який включає в ділянці плеча задню гілку променевої колатеральної артерії разом з $4-5$ перфорантними гілками та задній шкірний нерв передпліччя, а також судини зворотної променевої артерії в ділянці передпліччя. В тканини також включено судинні сплетіння м'яких тканин ділянок зовнішнього надвиростка плеча та ліктьового відростка

Клінічний приклад. Хворий С., 53 років отримав важку загальну високовольтну травму, опіки III ст правої верхньої кінцівки 5\% ПТ, рановим дефектом задньої поверхні ліктьового суглоба та передпліччя. Після висічення некрозу на 3 добу здійснено пластику рани зовнішнім подовженим клаптем плеча та передпліччя (рис. 21).
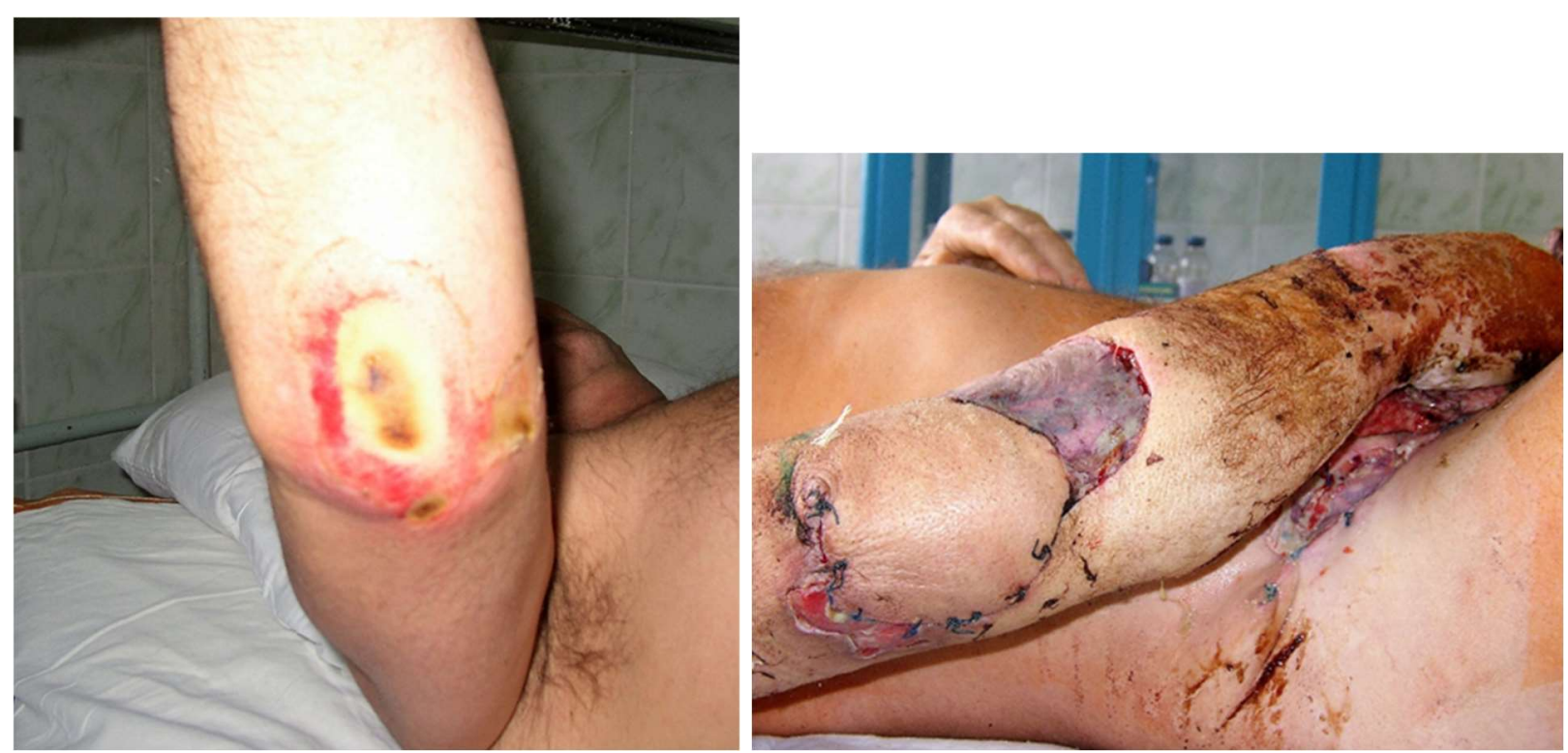

Рис. 21. Пастика рани задньої поверхні ліктьового суглоба та передпліччя зовнішнім подовженим клаптем плеча та передпліччя 
TRADITIONAL MEDICINE AND PHARMACOLOGY. ACHIEVEMENTS, INNOVATIONS, AND ALTERNATIVES

\subsubsection{3. Клапті пахової ділянки з осьовим кровообігом}

При дефіциті тканин на сегментах кінцівки, що оточують дефект, найбільш перспективним $є$ клапті пахової ділянки з осьовим кровообігом на тимчасовій судинній ніжці. Живлення тканин клаптів забезпечується поверхневою та глибокою артеріями, що огинають клубову кістку, а також поверхневою нижньою надчеревною артерію з однойменними венами [411413].

\section{Паховий клапоть на поверхневій артерії, щчо огинає клубову кістку}

Клапоть базується на кровопостачанні від поверхневої артерії, що огинає клубову кістку (ПАОКК), яка відгалужується від стегнової артерії нижче пахвової зв'язки. Артерія пронизує глибоку фасцію в медіальній частині кравцевого м'яза, виходить у підшкірну клітковину і живить шкіру над та під пахвовою зв'язкою. Вісь клаптя знаходиться паралельно і нижче на 2-3 см пахвової зв'язки. Максимальна ширина клаптя визначається шляхом пальцевого защемлення шкіри, що включається в клапоть, при напруженості оточуючих тканин. Здійснюється маркування клаптя та проекція судин. Біля верхнього внутрішнього краю клаптя розмічається рівнобедрений трикутний клапоть із сторонами 4-5 см для закриття живлячої ніжки у іiї основи (рис. 22).

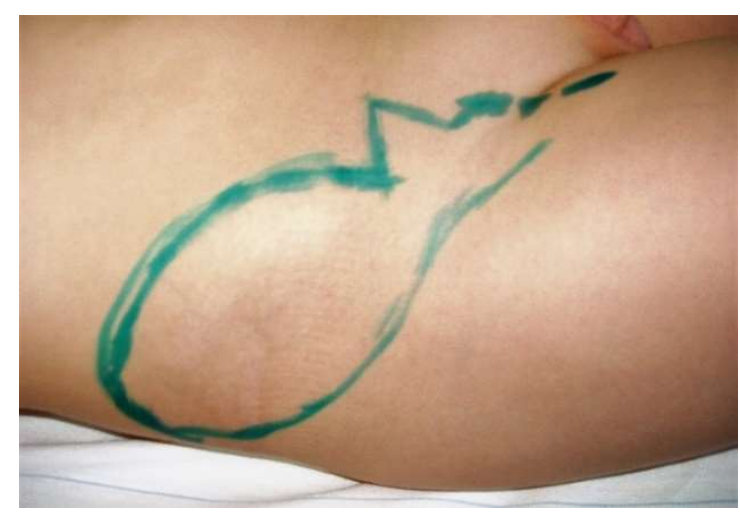

A

Рис. 22 (А) маркування пахового клаптя. У верхній медіальній частині клаптя визначений трикутний клапоть. (Б) піднятий сформований паховий клапоть.

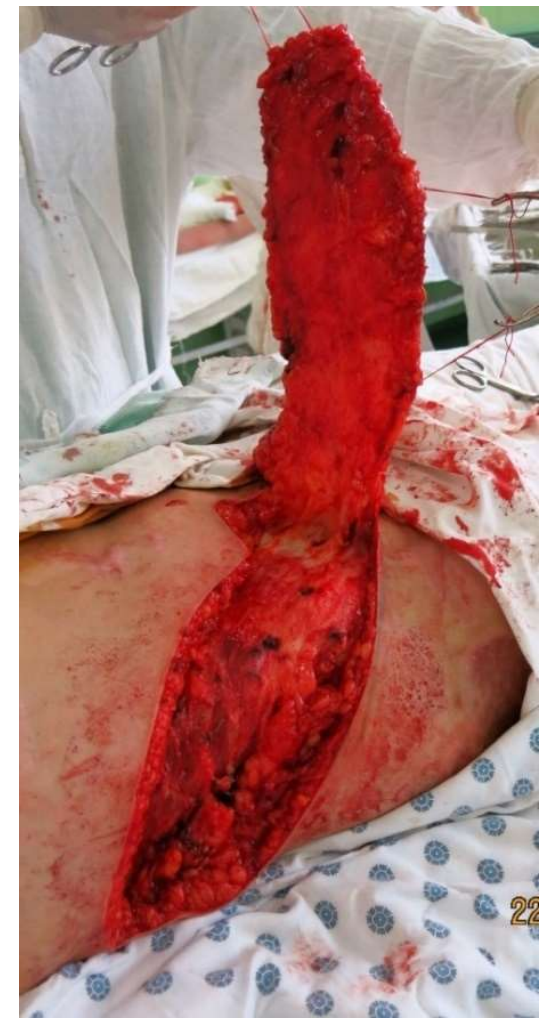


TRADITIONAL MEDICINE AND PHARMACOLOGY. ACHIEVEMENTS, INNOVATIONS, AND ALTERNATIVES

По периферії клаптя розсікається шкіра разом 3 підшкірною клітковиною до глибокої фасції. Клапоть виділяється надфасціально до латерального краю кравцевого м'яза. На цьому рівні розсікається фасція і відсепарування здійснюється разом з фасцією над якою проходить ПАОКК до медіального краю м'яза. Виділяючи артерію медіально формується судинна ніжка. Після підняття пахового клаптя і часткової мобілізації країв рани, донорський дефект ушивається. Шляхом обертання навколо основи пахового клаптя попередньо сформованого трикутного клаптя закривається живляча ніжка, чим усувається можливість ії пошкодження та перекручування. Сегмент верхньої кінцівки підводиться рановою поверхнею до клаптя i підшивається до країв. Сегмент фіксується міцними швами до тканин стегна та (чи) передньої черевної стінки.

Через 3 тижні після приживлення клаптя, живляча ніжка відсікається від материнської основи, а клапоть моделюється на місці його фіксації.

Клінічний приклад. Хвора К., 18 років поступила 3 ураженням електричним струмом низької напруги лівого передпліччя, променевозап'ясткового суглоба, кисті. Травма 2 години тому. Через 1 добу здійснено видалення некротичних тканини нижньої третини передпліччя, променевозап’ясткового суглоба та кисті. Дно рани складають оголені сухожилки розгиначів кисті та пальців. У лівій паховій області сформовано клапоть 3 включенням поверхневої артерії, що огинає клубову кістку розміром $12 \mathrm{~cm} \mathrm{х}$ 18 см. Руку підведено дефектом до клаптя, який підшито до країв рани. Руку фіксовано пов'язками. Післяопераційний період проходив без ускладнень (рис. 23).

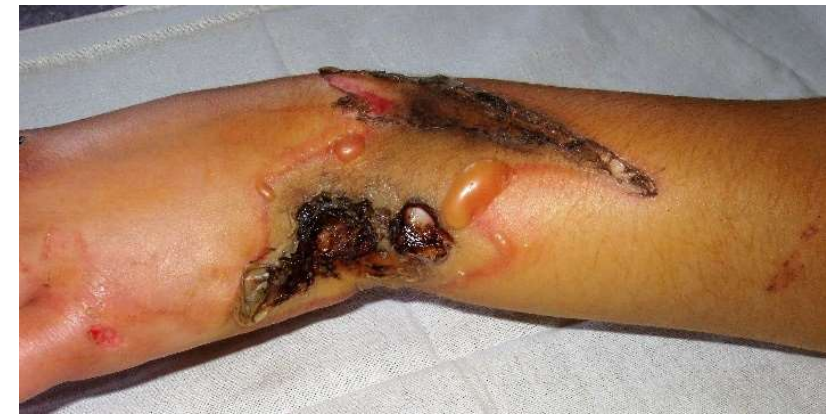

A

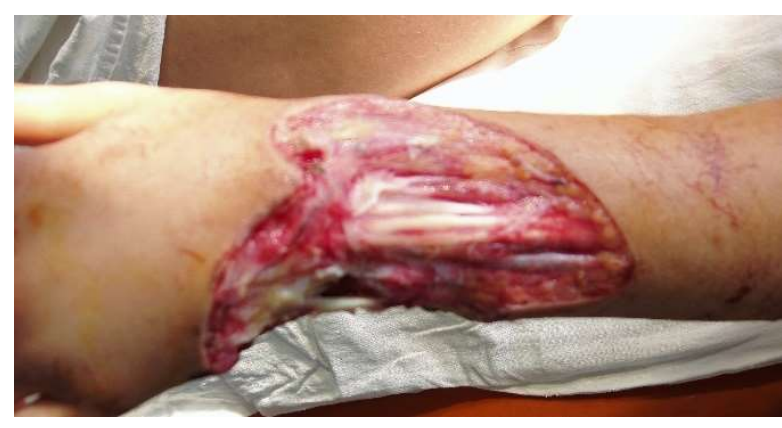

Б 


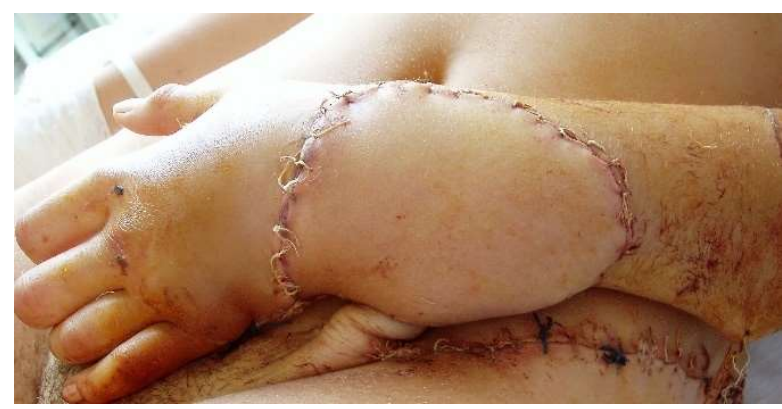

$\mathrm{B}$

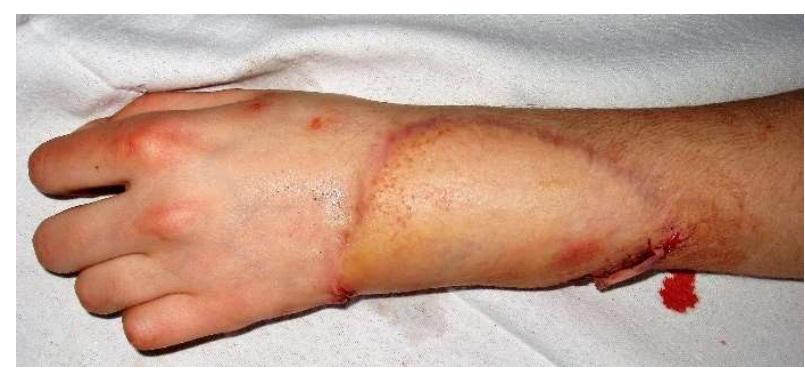

$\Gamma$

Рис. 23. (А) ураження передпліччя електричним струмом; (Б) стан після видалення некрозу на 2 добу; (В) пластика дефекту паховим клаптем на поверхневій артерії, що огинає клубову кістку; (Г) добрий результат лікування після операції через 6 місяців.

Клінічний приклад. Хворий С., 53 років отримав важку загальну високовольтну травму, опіки III ст правої верхньої кінцівки 5\% ПТ. Поступив у клініку через 1 годину після травми. Виконано некрофасціотомії 3 розкриттям фасціально-м’зових футлярів згинальної та розгинальної груп на правому передпліччі, розсіченням карпальної зв'язки та проведенням розрізів і розкриттям фасціально-м'язових футлярів долонної групи власних м'язів кисті. Видалені уражені покривні тканини передньої ліктьової поверхні передпліччя. Таким чином були оголені всі сухожилки згиначів в нижній та середній третинах передпліччя. Виділений серединний нерв без ознак перериву.

На 10 добу після зменшення набряку здійснено пластику дефекту передньої поверхні передпліччя паховим шкірно-жировим клаптем 3 включенням в нього судин системи поверхневої артерії, що огонає клубову кістку. Розміри клаптя склали $12 \times 20$ см. Залишкові рани середньої та верхньої третини передпліччя закрито шляхом вільної АДП.

Другий етап по відсіченню живильної ніжки та часткову корекцію клаптя здійснили через 4 тижні. Приживлення клаптя повне (рис. 24). 


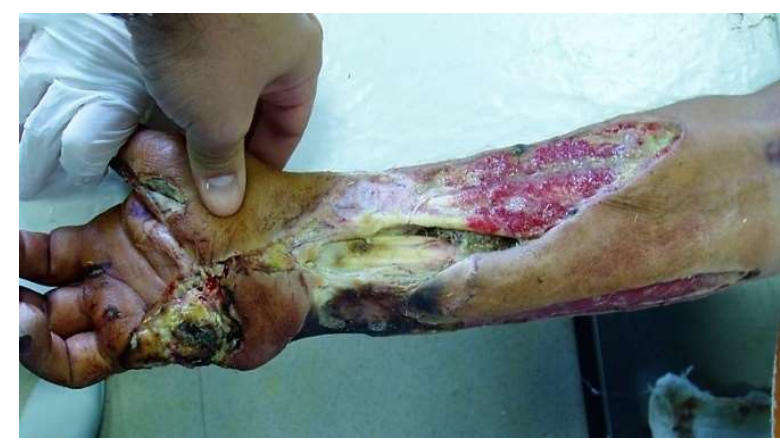

A

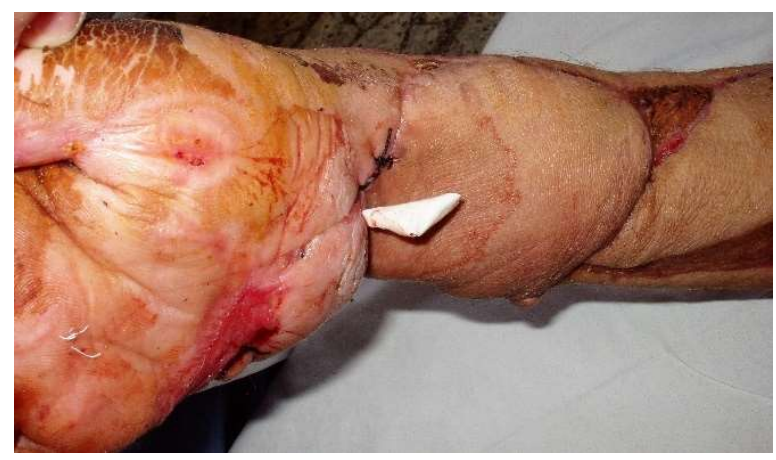

B

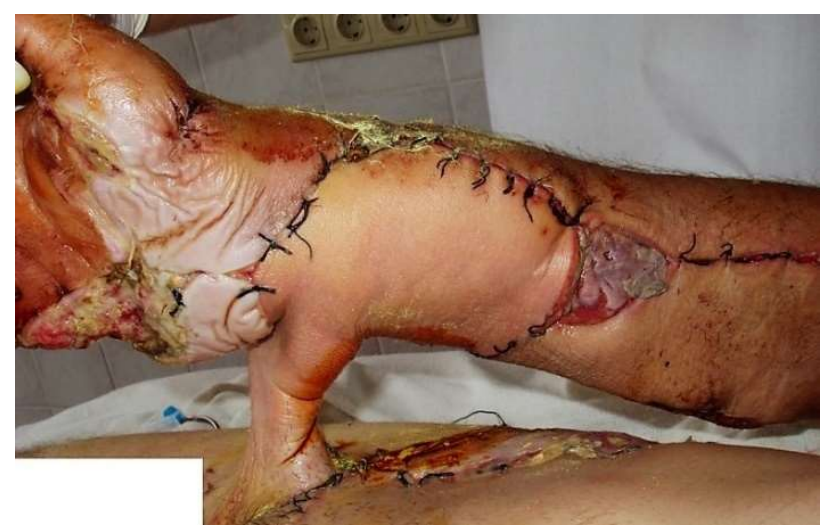

Б

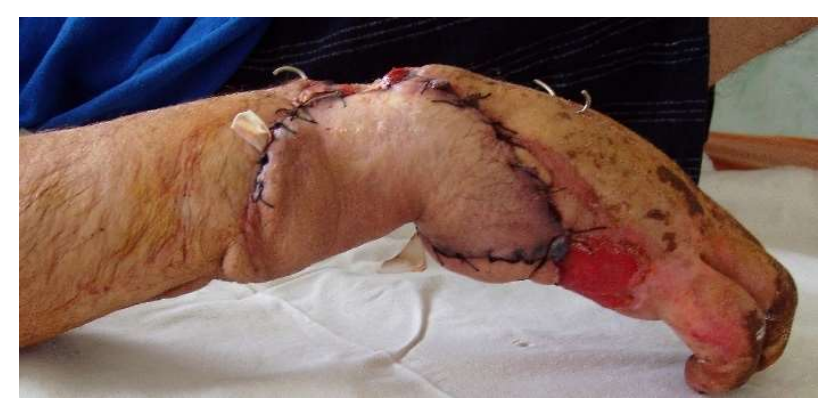

Рис. 24. Хворий С. (А) гнійно-некротичний дефект передпліччя та кисті після високовольного електорураження; (Б) пластика дефекту пластика дефекту паховим клаптем на поверхневій артерії, що огинає клубову кістку; $(\mathrm{B}, \Gamma)$ результат операції через 4 тижні.

Клінічний приклад. Хворий М., 63 років, отримав важку загальну високовольтну травму, опіки III ступеня правої верхньої кінцівки 5\% ПТ. Поступив у клініку через 1 годину після травми. Після проведення інфузійної терапії через 2 години виконано некрофасціотомії з виділенням променевого і ліктьового судинно-нервових пучків, розкриттям фасціально-м'зових футлярів згинальної та розгинальної груп на правому передпліччі, розсіченням карпальної зв'язки та проведенням розрізів і розкриттям фасціально-м'язових футлярів долонної групи власних м'язів кисті. Видалені уражені покривні тканини передньої та ліктьової поверхні передпліччя. Таким чином були оголені всі сухожилки згиначів в нижній та середній третинах передпліччя. 
TRADITIONAL MEDICINE AND PHARMACOLOGY. ACHIEVEMENTS, INNOVATIONS, AND ALTERNATIVES

Виділений серединний нерв без ознак перериву. Видалений некроз в ділянці ліктьового суглоба.

Через 2 доби проведено додатково некректомії в ділянці правого передпліччя з висіченням сухожилків поверхневого згинача пальців. Для збереження функції дистальні кінці останнього підшито до сухожиль глибокого згинача на рівні карпального каналу.

На 7 добу після зменшення набряку здійснено пластику дефекта у місцях де були прилеглі м'язи вільними трансплантатами. Після приживлення трансплантатів на 12 добу здійснено пластику карпального каналу передньої поверхні передпліччя паховим шкірно-жировим клаптем на поверхневій артерії, що огонає клубову кістку. Розміри клаптя склали 12х25 см.

Залишкові рани середньої та верхньої третини передпліччя, а також донорська ділянка закрито шляхом вільної АДП.

Другий етап по відсіченню живильної ніжки та часткову корекцію клаптя здійснили через 4 тижні. Приживлення клаптя повне (рис. 25).

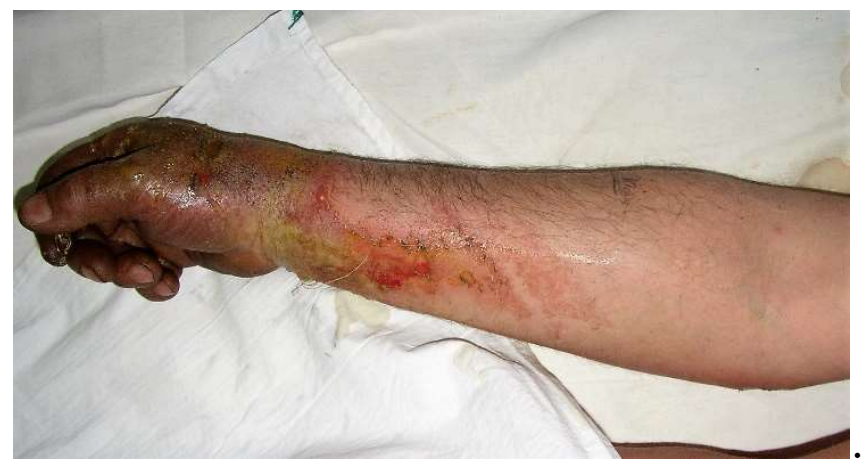

A

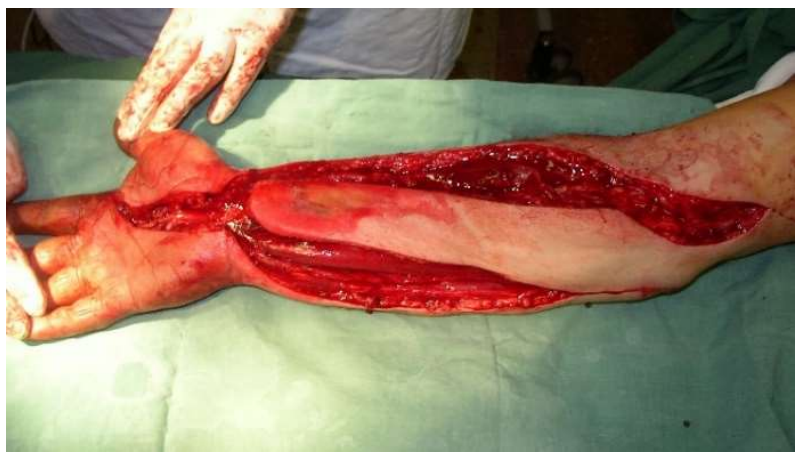

Б 


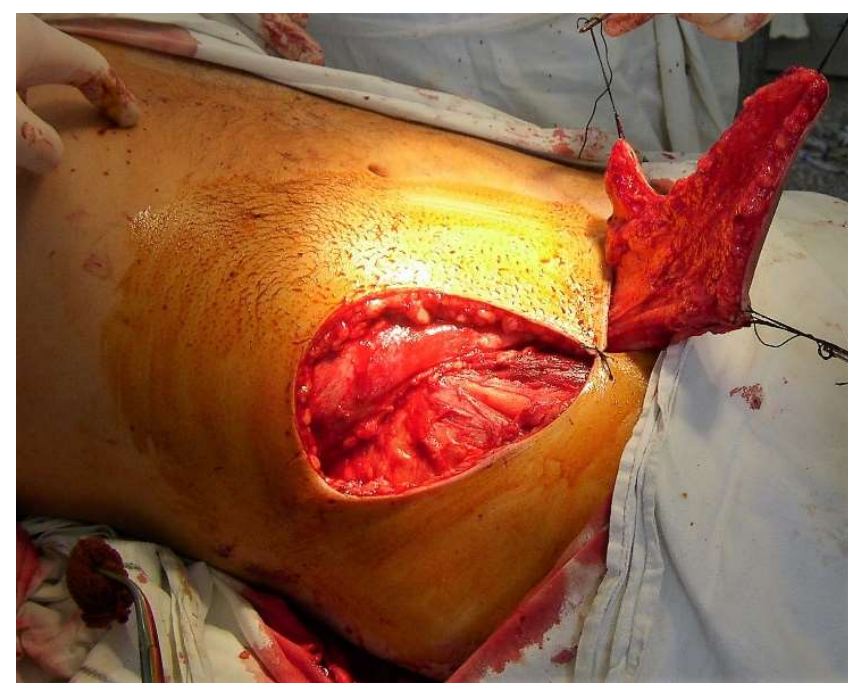

B

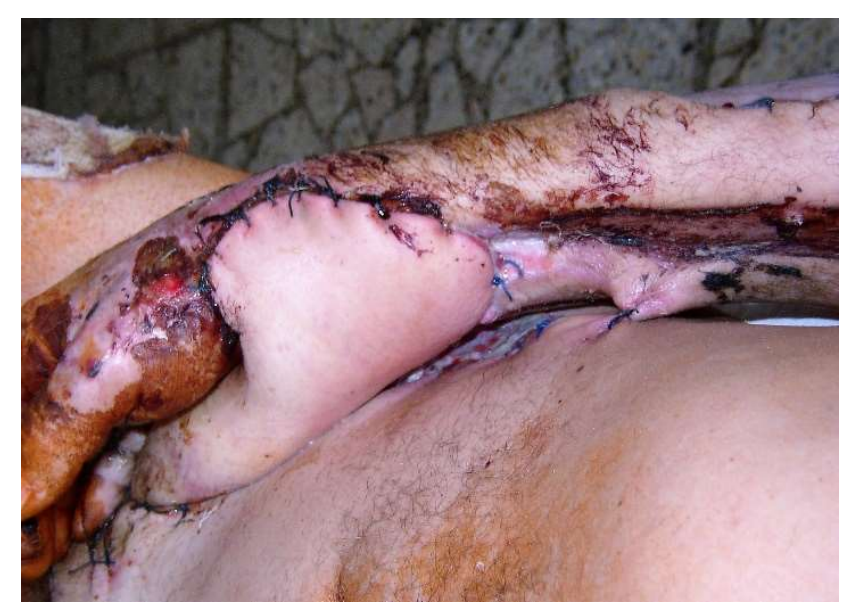

$\Gamma$

Рис. 25. (А) високовольтна електротравма правої верхньої кінцівки 5\%

ПТ; (Б) некрофасціоміотомії на правому передпліччі та кисті; (В) сформований паховий клапоть на ПАОКК; (Г) пластика дефекту долонної поверхні кисті та нижньої третини передпліччя паховим клаптем.

Комбінований шкірно-кістковий клапоть на поверхневій артерії, щчо огинає клубову кістку з ретроградним кровотоком

Для заміщення дефектів м'яких тканин та дистального відділу променевих кісток на обох передпліччях у однієї дитини використали комбіновані шкірно-кісткові клапті на поверхневій артерії, що огинає клубову кістку.

Розмітка комбінованого шкірно-кісткового клаптя на ПАОКК 3 ретроградним кровотоком здійснюється з включення шкірної ділянки позаду передньої верхньої ості клубової кістки над гребнем клубової кістки [414-416]. В дистальній частині клаптя з периферії розсікається шкіра до глибокої фасції. Перфорантна артерія, як правило, знаходиться в проекції на 1-2 см вище гребня клубової кістки та на 5 см позаду від передньої верхньої ості клубової кістки. Над гребнем клубової кістки у проекції м'язового перфоранта ГАОКК розсікається зовнішній та внутрішній косі м'язи живота з утворенням м'язової муфти навкруги фрагмента гребня 3 включенням ГАОКК. Остання проксимально і дистально лігується із збереженням лише частини біля 
TRADITIONAL MEDICINE AND PHARMACOLOGY. ACHIEVEMENTS, INNOVATIONS, AND ALTERNATIVES

кісткового фрагменту. За допомогою осциляторної пили випилюється кістковий фрагмент гребня клубової кістки. Таким чином, фрагменти клубової кістки, глибокої артерії та м'язової муфти залишаються у зв'язку з шкірним клаптем. Живлення всіх складових клаптя здійснюється від ПАОКК потім ретроградно через перфорант та судинну мережу навкруги кісткового фрагменту. Клапоть піднімається у подальшому звичайним методом 3 формуванням судинної ніжки 3 ПАОКК. Донорський дефект первинно ушивається після мобілізаціїі країв рани.

Передпліччя підводиться до клаптя рановим дефектом. Фрагмент клубової кістки вкладається в дефект променевої кістки і фіксується однією чи двома шпицями. Шкірним клаптем закривається дефект м’яких тканин. сегмент кінцівки додатково фіксується апаратом зовнішньої фіксації (АЗФ). На передпліччі проксимально встановлюють дві опори і одну - дві на кисті. Опори АЗФ жорстко фіксують між собою з невеликою компресією кісткового трансплантата.

Через 4-5 тижнів живляча ніжка відсікається і клапоть моделюється на місці [414-418].

Клінічний приклад. Хворий О., 5 років, поступив в клініку з гнійнонекротичними дефектами нижніх третин обох передпліч, дефектами обох променевих кісток в дистальних метафізах, згинально-розгинальними контрактурами пальців обох кистей, нейродистрофічному синдромі обох передпліч та кистей. Високовольтну електротравму отримав 1 міс тому. Лікувався в обласному опіковому відділенні. На рентгенограмах визначається вогнищевий остеопороз кісток зап'ястка та п'ястка, дефекти променевих кісток: ліворуч 3,5 см, праворуч - 4 см. Після висічення фіброзно-некротичних тканин на правому передпліччі виділені фрагменти променевої кістки i проведена резекція їх кінців. Утворився дефект довжиною 4 см. У правій паховій ділянці проведено формування комбінованого шкірно-кісткового клаптя на поверхневій артерії, що огинає клубову кістку з ретроградним кровотоком. 
TRADITIONAL MEDICINE AND PHARMACOLOGY. ACHIEVEMENTS, INNOVATIONS, AND ALTERNATIVES

При викроюванні шкірно-м'язового-кісткового клаптя виділений фрагмент глибокої артерії, що огинає клубову кістку разом з фрагментом крила клубової кістки $1,5 \times 1,5 \times 4,5$ см та м'язовою муфтою. Кістковий фрагмент клубової кістки розміщений в дефект променевої кістки і фіксований трансосально спицею. Дефект м'яких тканин закритий клаптем. Здійснена додаткова імобілізація за допомогою спицевого апарата зовнішньої фіксації. Другий етап втручання - відсічення живлячої ніжки проведено через 5 тижнів.

Через 1 тиждень проведено подібне втручання на лівому передпліччі із пластикою дефекта лівої променевої кістки довжиною 3,5 см (рис. 26).

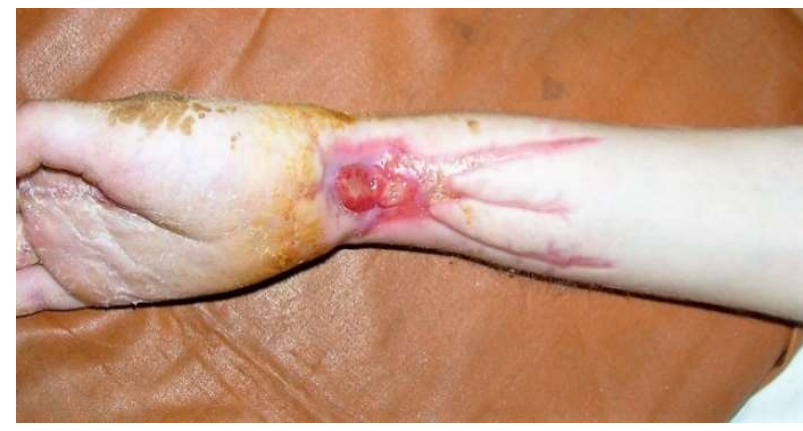

A

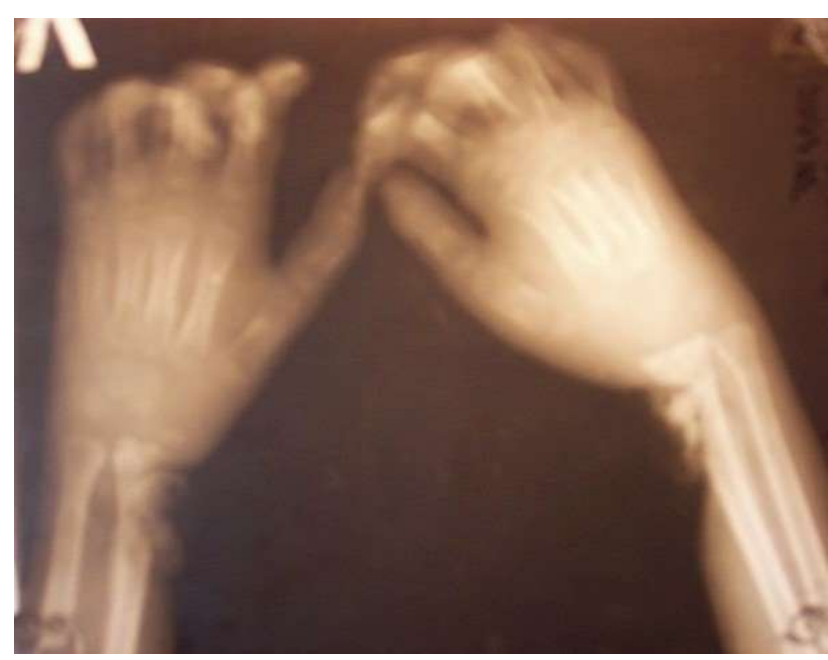

B

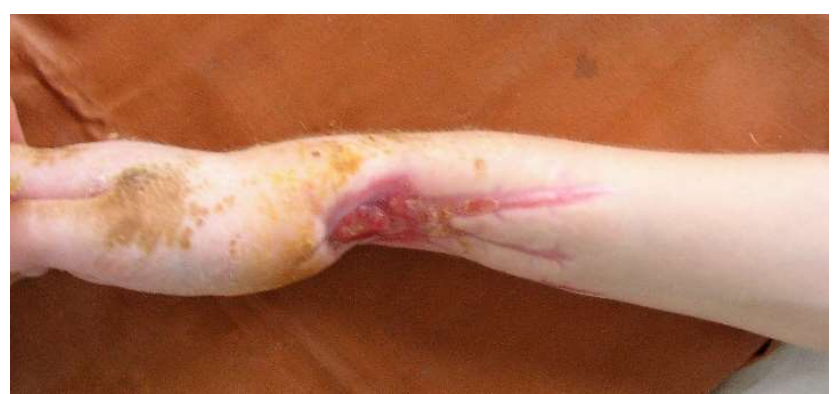

Б

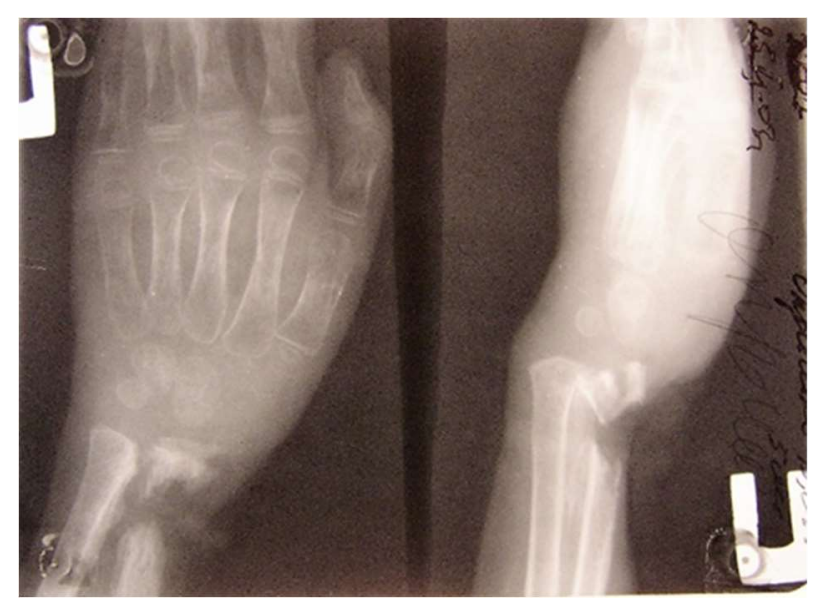

$\Gamma$ 
TRADITIONAL MEDICINE AND PHARMACOLOGY. ACHIEVEMENTS, INNOVATIONS, AND ALTERNATIVES

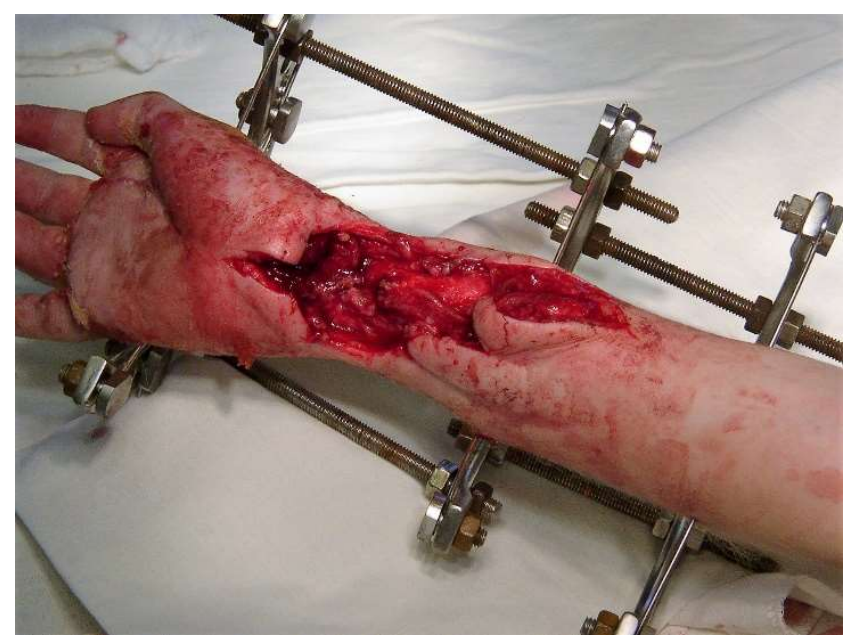

Д

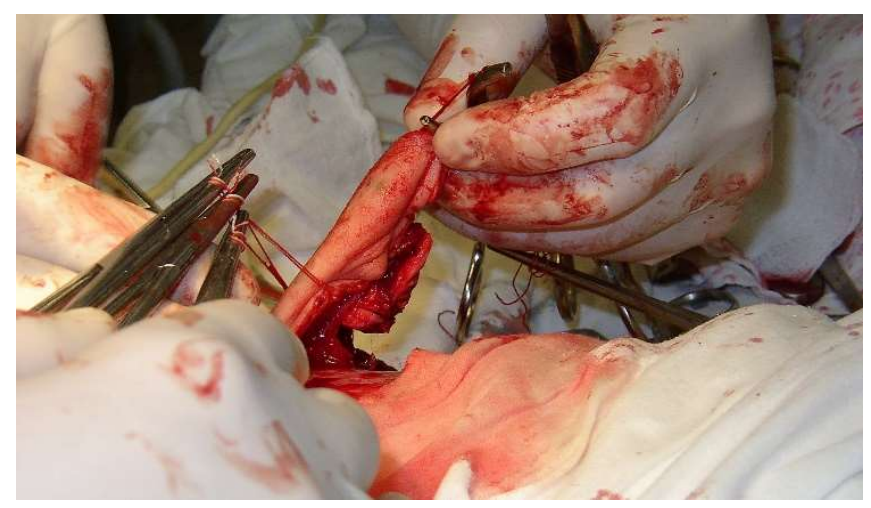

Ж

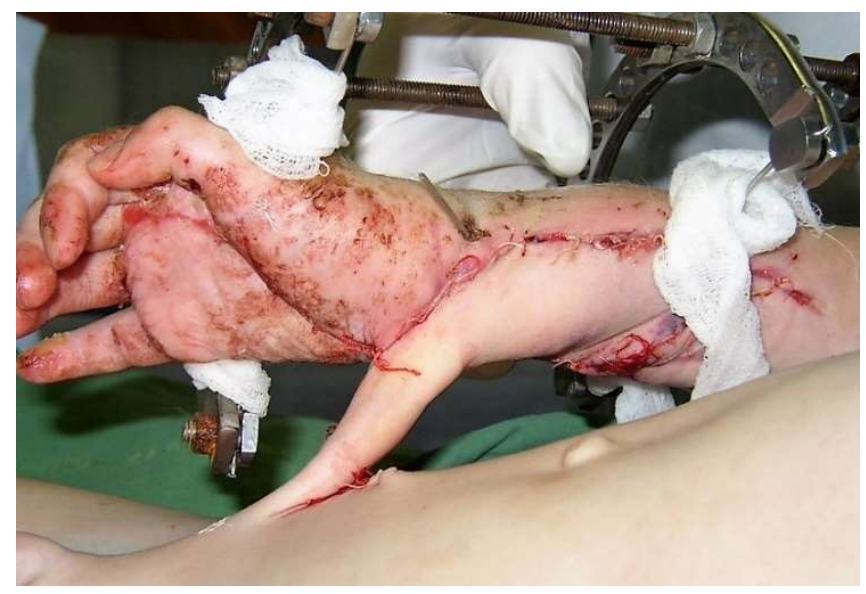

I

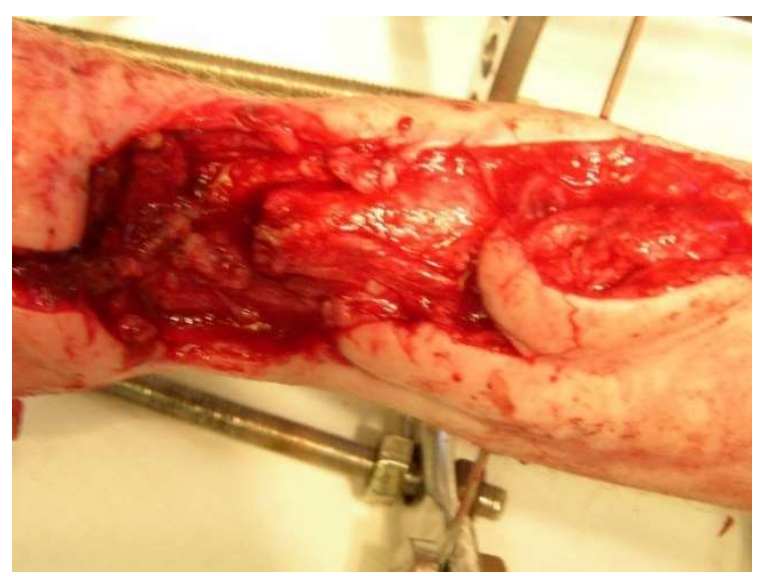

$\mathrm{E}$

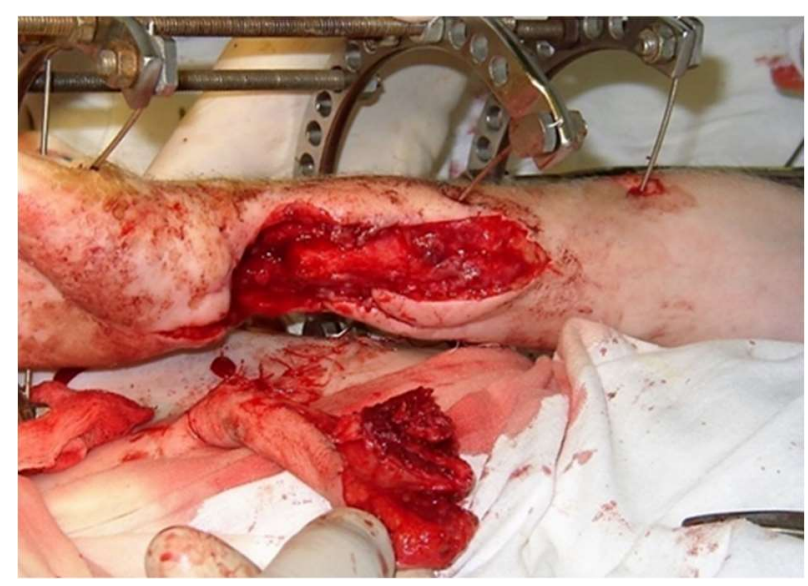

3

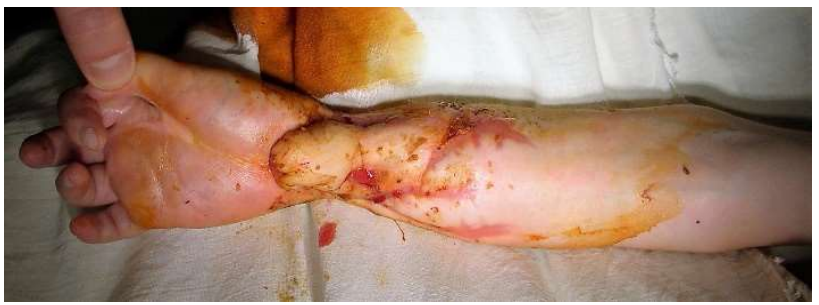

K 
TRADITIONAL MEDICINE AND PHARMACOLOGY. ACHIEVEMENTS, INNOVATIONS, AND ALTERNATIVES

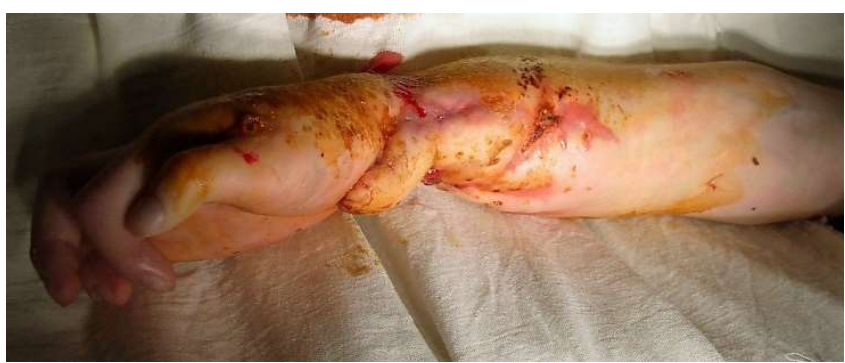

Л

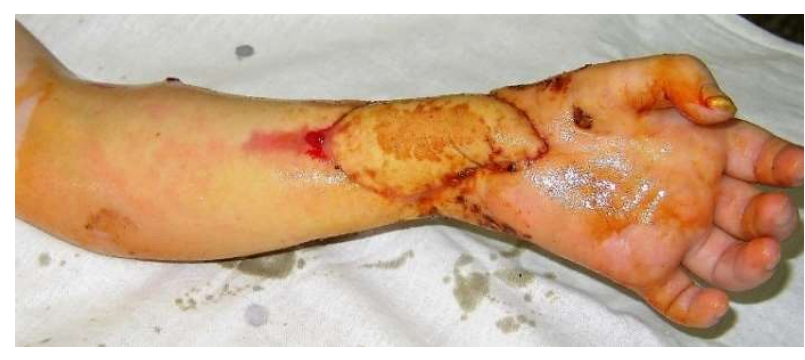

M

Рис. 26. (А, Б) гнійно-некротичний дефект нижньої третин правого передпліччя; (B, Г) рентгенограма правого передпліччя та кисті. Дефект променевої кістки в дистальному епіметафізі; (Д, Е) резекція дистальної епіметафізарної частини правої променевої кістки в зоні ураження.

Накладання АЗФ для фіксаціїі сегменту «передпліччя-кисть»; (Ж) формування та підняття шкірно-кісткового клаптя на ПАОКК та фрагменту 3 гребня клубової кістки на перфорантних судинах; (3) суміщення рани передпліччя та шкірно-кісткового клаптя; (I) пластика дистального епіметафізу променевої кістки кістковим фрагментом та клаптем на ПАОКК; (К, Л) стан після відсікання живлячої ніжки на правому передпліччі (6 тижнів після пластики); (М) стан після відсікання живлячої ніжки на лівому передпліччі (7 тижнів після пластики).

\subsubsection{4. Клапті з передньої черевної стінки}

У деяких пацієнтів 3 важкими опіками верхньої кінцівки та ушкодженнями сухожиль, кісток та суглобів використати місцеві чи регіональні клапті не можливо i, у таких випадках клапті з передньої черевної стінки є методом вибору [419-420].

Шкірна пластика клаптями 3 передньої черевної стінки - давній метод хірургічного утворення підшкірної кишені для закриття дефектів дистальних відділів кінцівки. Для зменшення функціональних та естетичних непривабливих результатів використовуються різноманітні модифікації таких клаптів. 
TRADITIONAL MEDICINE AND PHARMACOLOGY. ACHIEVEMENTS, INNOVATIONS, AND ALTERNATIVES

Кровопостачання черевної стінки розділяється за Huger W.E. Jr. (1979) [421] на три анатомічні зони.

Зона I розташована у верхніх та середньоцентральних ділянках черевної стінки і кровозабезпечується вертикально орієнтованими перфорантами глибоких верхніх та нижніх надчеревних аретрій.

Зона II знаходиться в нижній ділянці черевної стінки і живиться надчеревною аркадою, поверхневими нижніми надчеревними, та поверхневими зовнішніми статевими артеріями, а також поверхневими артеріями, що огинають клубові кістки. Перфоранти від глибоких аретрій, що огинають клубові кістки забезпечують ділянки шкіри вздовж гребнів клубових кісток від передніх верхніх їхніх остей.

Зони III розташовані на бічних поверхнях (фланках) черевної стінки і кровопостачаються нижніми міжреберними та поперековими артеріями (рис.27).

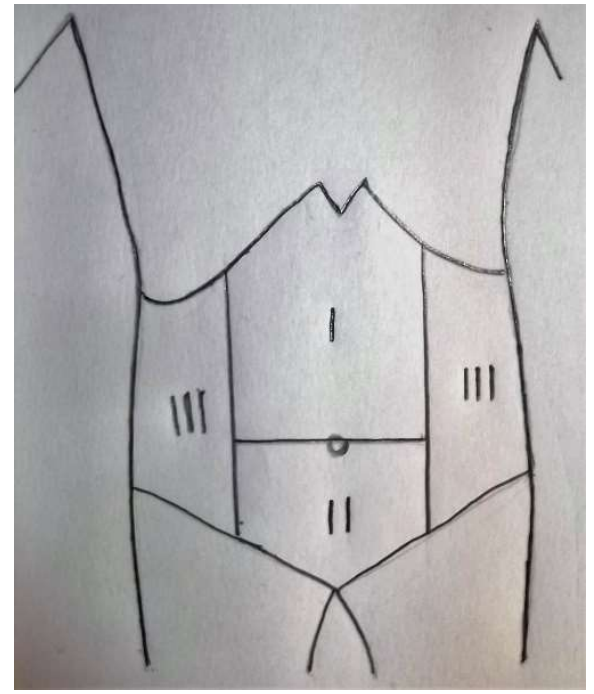

Рис. 27. Анатомічні зони передньої черевної стінки в залежності від домінуючого кровопостачання

Використовуються клапті передньої черевної стінки при великих пошкодженнях м'яких тканин разом із сухожилками, кістками та суглобами, невеликих глибоких дефектах у дітей для збереження неушкоджених ділянок кисті. 
TRADITIONAL MEDICINE AND PHARMACOLOGY. ACHIEVEMENTS, INNOVATIONS, AND ALTERNATIVES

Хірургічне втручання по відновленню шкірних покривів складається 3 декількох етапів.

I етап здійснюється після видалення нежиттєспроможних тканин та зменшення запалення в ураженій ділянці.

Для кожного пацієнта, в залежності від місця та розмірів дефекту, розташування клаптя та його форма плануються індивідуально. Однак, Kelleher J.C. (2004) [422] визначив середні розміри клаптів в залежності від їхньої локалізації (табл. 1).

Таблиця 1.

\section{Вимоги до розмірів клаптів різних частин верхньої кінцівки} відповідно до анатомічних регіонів

\begin{tabular}{|c|l|c|}
\hline Регіон & \multicolumn{1}{|c|}{ Локалізація } & Розміри клаптів (см) \\
\hline А & 1 палець до 1 ПФС & 9 × 8 \\
\hline Б & Тенар & 13 × 12 \\
\hline В & Долонна поверхня кисті & 12 × 10 \\
\hline Г & Поверхні пальців & $7 \times 10$ \\
\hline Д & Тильна поверхня кисті & 12 × 10 \\
\hline Е & Обидві поверхні кисті і пальців & $20 \times 20$ \\
\hline
\end{tabular}

Формування клаптів, що наведені в таблиці 4. можливо у будь-якому місці на передній черевній стінці оскільки співвідношення довжини до ширини є сприятливим. Проте кровопостачання може бути збільшено при включенні до клаптя осьових судин такі як I та II зони черевної стінки 3 поверхневою нижньочеревною судинною системою.

\section{Формування клаптів з передньої черевної стінки}

Розріз шкіри та підшкірної клітковини здійснюється після маркування дефекту до м'язово-апоневротичного шару передньої черевної стінки. Жирова клітковина в донорській ділянці не залишається для запобігання можливості іiі інфікування та гнійного запалення. Клапоть піднімається до своєї основи. За допомогою ножиць видаляється «зайва» жирова клітковина до візуалізації субдермального судинного сплетіння тільки на площі фіксації клаптя до 
TRADITIONAL MEDICINE AND PHARMACOLOGY. ACHIEVEMENTS, INNOVATIONS, AND ALTERNATIVES

ранового дефекту реципієнтної зони. Краї донорської рани частково мобілізуються i, при неможливості їхнього зшивання між собою, фіксуються окремими швами до апоневрозу. Залишкова рана закривається вільними трансплантатами.

Сегмент кінцівки підводиться рановим дефектом до клаптя і краї зшиваються між собою. Кінцівка фіксується у необхідному положенні.

Другий етап втручання здійснюється через 3 - 4 тижні. Живляча ніжка відсікається від материнської основи та виконується моделювання клаптя на місці. Донорська рана також ушивається.

Розташування сегмента верхньої кінцівки в залежності від локалізації ураження

Для долонних дефектів кисті рука розташовується у положенні супінації до черевної стінки з відведенням 1 пальця за допомогою шпиць Киршнера.

При тильних дефектах кисть розміщується у фізіологічному положенні також з відведенням 1 пальця.

При двосторонніх ураженнях кисті та пальців потрібна велика площа клаптя до 20 х 20 см. Цей клапоть формується з нижньою основою та включає одну чи дві поверхневих нижніх надчеревних судин.

Для закриття дефектів долонної поверхні передпліччя потрібен шкірний клапоть з верхньою основою. При цьому рука фіксується у максимальному положенні супінації. Розміри клаптя залежатимуть від дефекту. Через свою широку основу включення осьових судин у склад клаптя не обов'язкове.

Шкіра для тильної поверхні передпліччя може бути використана у будьякому відділі черевної стінки і клапоть формується на широкій нижній основі.

Необхідно враховувати, що точне співставлення клаптя 3 рановою поверхнею усуває негативний вплив напруги, перегинання або кручення клаптя і зменшує можливість ішемічних розладів.

Клінічний приклад. Хворий К., 48 років., отримав важку загальну високовольтну травму, опіки III ступеня правої верхньої кінцівки $2 \%$ ПТ. Поступив у клініку через 2 тижні після травми з іншого лікувального закладу. 
TRADITIONAL MEDICINE AND PHARMACOLOGY. ACHIEVEMENTS, INNOVATIONS, AND ALTERNATIVES

Здійснені некректомії по типу нетипової ампутації кисті на рівні п’ясткових кісток.

Через 3 доби після зменшення набряку здійснено пластику кукси кисті шкірно-жировим клаптем 3 передньої черевної стінки правої здухвинної ділянки III зони з включенням в нього судин системи поверхневої нижньої надчеревної артерії. Розміри клаптя склали 10х12 см. Донорська рана ушити первинно після мобілізації країв. Другий етап по відсіченню живильної ніжки та асткову корекцію клаптя здійснили через 4 тижні. Приживлення клаптя повне (рис. 28).

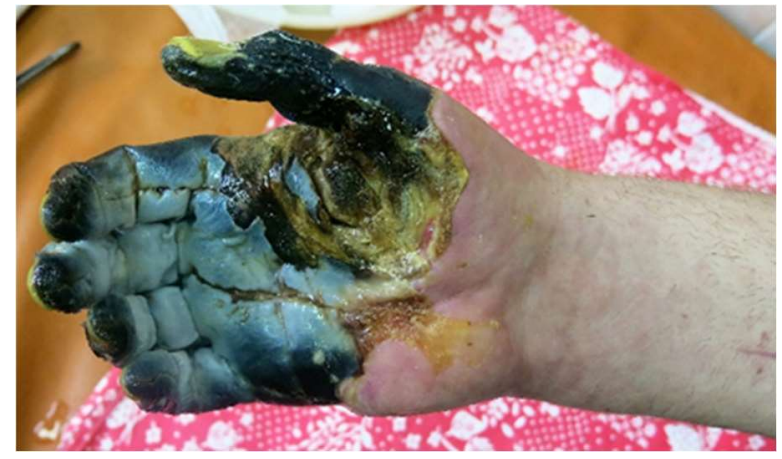

A

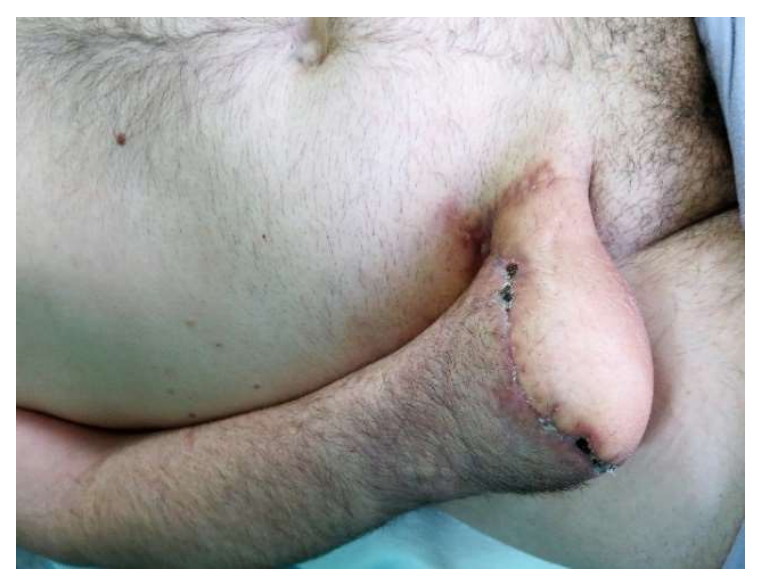

$\mathrm{B}$

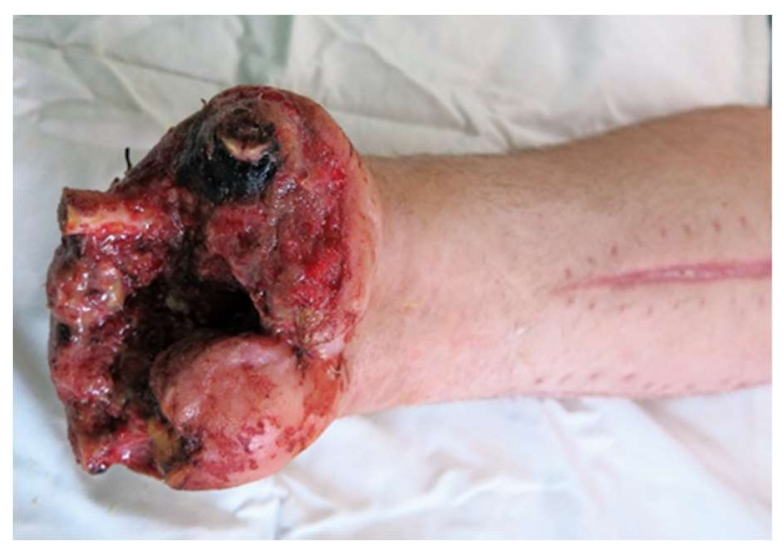

Б

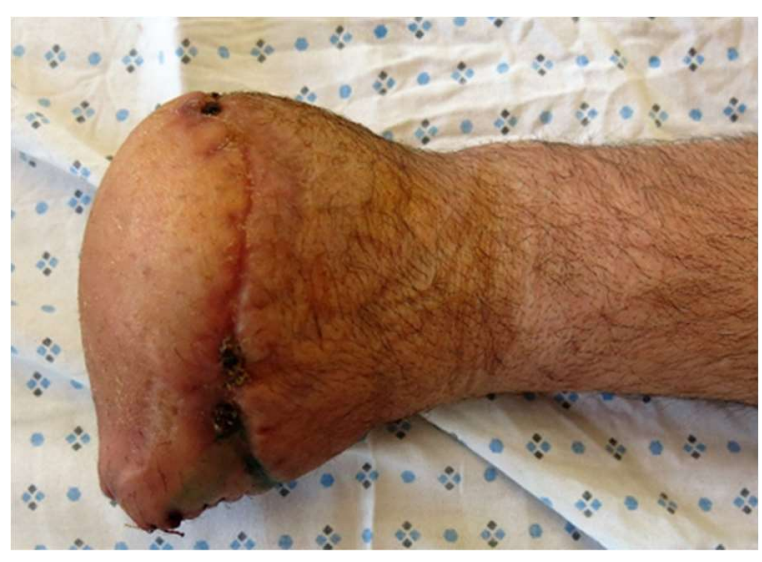

$\Gamma$

Рис. 28. (А) субтотальний некроз кисті після електроураження; (Б) некректомія по типу нетипової ампутації; (В) пластика кукси кисті клаптем 3 передньої черевної стінки здухвинної ділянки III зони з включенням в нього судин системи поверхневої нижньої надчеревної артерії.; (Г) результат після операції. 
TRADITIONAL MEDICINE AND PHARMACOLOGY. ACHIEVEMENTS, INNOVATIONS, AND ALTERNATIVES

Клінічний приклад. Дитина В, 1,5 років, отримала низьковольтне електричне ураження тильної поверхні основної та променевої поверхні середньої фаланг 3 пальця правої кисті. На 2 добу після висічення некрозу рановий дефект закрито клаптем 3 передньої черевної стінки. Після приживлення клаптя на 21 добу здійснено відсічення тимчасової живлячої ніжки. Таким чином. вдалося закрити дефект без використання тканин пальців та кисті і їх вторинного пошкодження після забору місцевих клаптів (рис. 29).

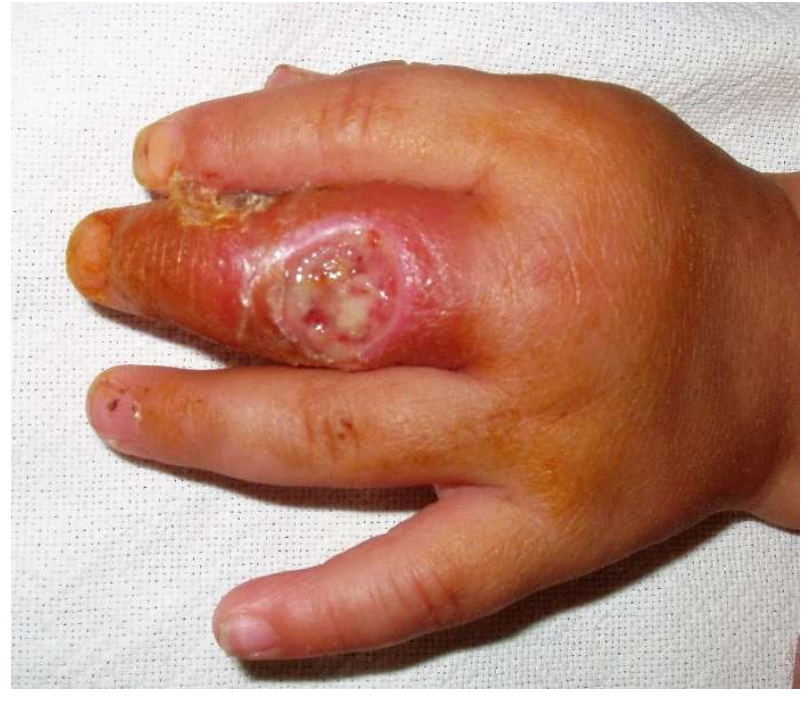

A

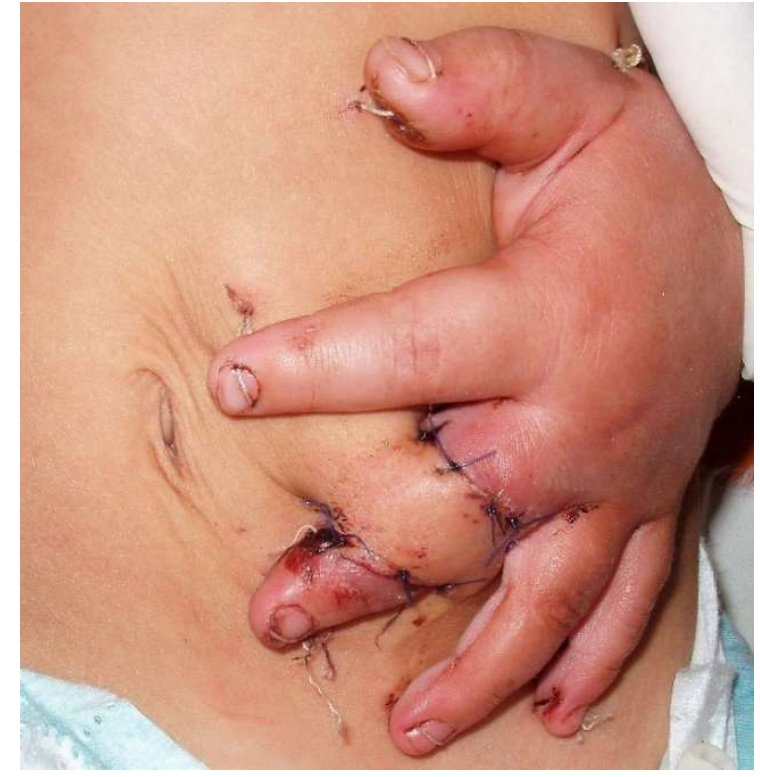

Б

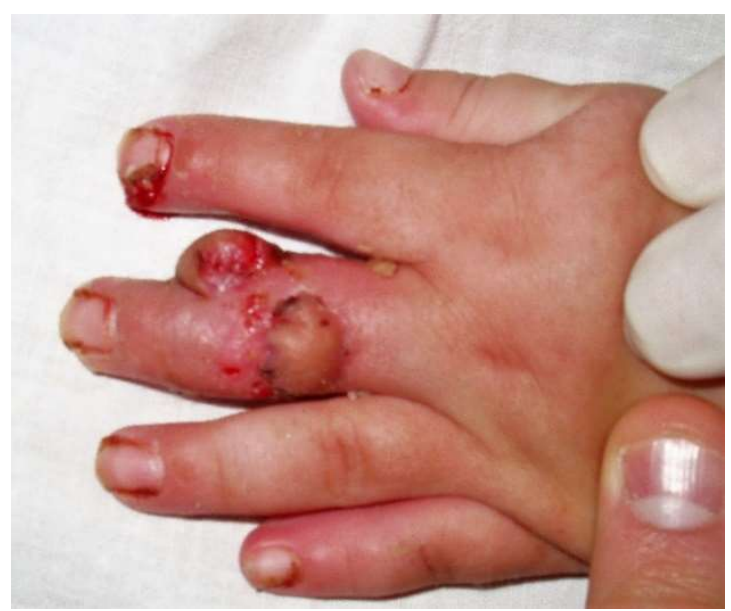

$\mathrm{B}$

Рис. 29. (А) ураження пальця низьковольтним електричним струмом;

(Б) пластика дефекту 3 пальця клаптем передньої черевної стінки на тимчасовій живлячій ніжці; (В) після відсічення живлячої ніжки клаптя. 
TRADITIONAL MEDICINE AND PHARMACOLOGY. ACHIEVEMENTS, INNOVATIONS, AND ALTERNATIVES

2.6.3. Хірургічне лікування дефектів проксимальних відділів передпліччя та ліктьового суглоба

Незалежно від етіологічних чинників рани ділянки ліктьового суглоба є інвалідизуючими факторами, які впливають як на працездатність, так і на якість життя.

Реконструктивні і відновні втручання при ураженні ліктьового суглоба та передпліччя можуть бути різними в залежності від кожної анатомічної ділянки. Рани передпліччя можуть бути закриті вільними трансплантатами. Однак великі ранові поверхні з оголенням судинних та нервових утворень, сухожиль чи кісток потребують швидкого закриття повноцінними тканинами, щоб запобігти тугорухомості та контрактурам. Оскільки при великих опіках місцеві тканини залучаються до зони пошкодження або можуть бути зовсім відсутніми застосовуються інші варіанти пластики.

Відновлення тканин ділянки ліктьового суглоба та передпліччя відкладається до очищення ран та зменшення ознак запального процесу, однак повинно бути достатньо раннім для забезпечення фізіологічної рухливості.

\subsubsection{1. Торакоабдомінальні клапті на тимчасовій судинній ніжці}

Торакоабдомінальні клапті на живлячій ніжці вперше описані у 1940-х роках Brown J.B. et al (1945), Cannon B, Trott A.W. (1949) [423].

Широка мережа перфорантів, що мають походження з верхніх та нижніх надчеревних, міжреберних, підреберних та поперекових артерій, поверхневих та глибоких артерій, що огинають клубову кістку забезпечують багато варіантів у конструкції клаптів черевної та грудної стінки. Такі клапті застосовуються для закриття великих дефектів передпліччя, кисті та ліктьового суглоба, коли місцеві, регіональні та вільні клапті використати неможливо [424].

Враховуючи особливості кровопостачання грудної та черевної стінки, шкірно-фасціальні клапті формуються у двох варіантах. 
TRADITIONAL MEDICINE AND PHARMACOLOGY. ACHIEVEMENTS, INNOVATIONS, AND ALTERNATIVES

\subsubsection{1. Торакоабдомінальний клапоть на тимчасовій судинній} ніжці 3 живленням від задніх та середніх міжреберних та поперекових перфорантних судин

Торакоабдомінальний клапоть отримує живлення з задніх та середніх міжреберних та поперекових перфорантних систем. Формування клаптя здійснюється у напрямку від середньої лінії живота до рівня середньої пахвової лінії - основи клаптя (рис. 30). Розміри клаптів можуть складати від 14-16 см до 20-22 см.
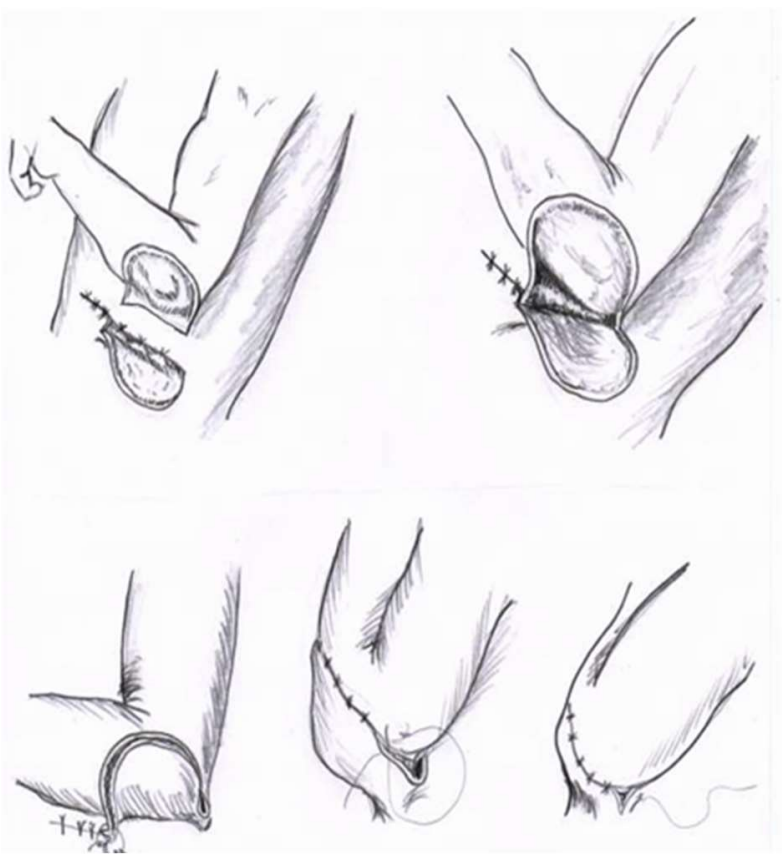

Рис. 30. Схема формування торакоабдомінального клаптя на тимчасовій судинній ніжці з живленням від задніх та середніх міжреберних та поперекових перфорантних судин

Клінічний приклад. Хворий $Є$., 14 років поступив в клініку з приводу загальної електротравми, ураження високовольтним електричним струмом лівого ліктьового суглоба, передпліччя, кисті, з пошкодженням ліктьового суглоба та ліктьового нерва. Високовольтну елктротравму отримав 3 доби тому. Лікувався в обласному опіковому відділенні. Після передопераційної підготовки постраждалому на 2 добу виконано некректомію 3 висіченням уражених м'язів передпліччя, кисті, резеційовано ліктьовий відросток лівої ліктьової кістки. Утворився глибокий дефект тканин з оголенням зовнішньо- 
TRADITIONAL MEDICINE AND PHARMACOLOGY. ACHIEVEMENTS, INNOVATIONS, AND ALTERNATIVES

задньої поверхні ліктьового суглоба, ліктьової кістки, сухожиль та м’язів долонно-ліктьової поверхні передпліччя та кисті. Висічено некроз на лівій кисті з утворенням рани долонної поверхні 1 пальця та 1 міжпальцевого проміжку.

Через 3 доби після зменшення явищ запалення здійснено повторне видалення залишків некрозу i зроблено перфораційні отвори в епіметафізарних ділянках ліктьової та плечової кісток діаметром 3 мм. На лівій стороні тулуба сформувано шкірно-фасціальний торакоабдоміальний клапоть розмірами 16 см х 22 см. Основа клаптя розташована по середній пахвовій лінії і живлення відбувається з задніх та середніх міжреберних та поперекових перфорантних систем. Донорську рану закрито вільним трансплантатом. Ліву верхню кінцівку підведено до сформованого клаптя і передпліччя та кисть фіксовано швами до непошкоджених ділянок передньої черевної стінки. Клапоть підшитий к краям рани.

На протилежній стороні черевної стінки сформовано шкірнофасціальний клапоть на верхній основі розміром 8 см х 10 см з живленням від поперекових перфорантних судин. Клаптем здійснено закриття рани лівої кисті. Через 4 тижні здійснено відсічення живлячих ніжок клаптів та їх моделювання (рис. 31).

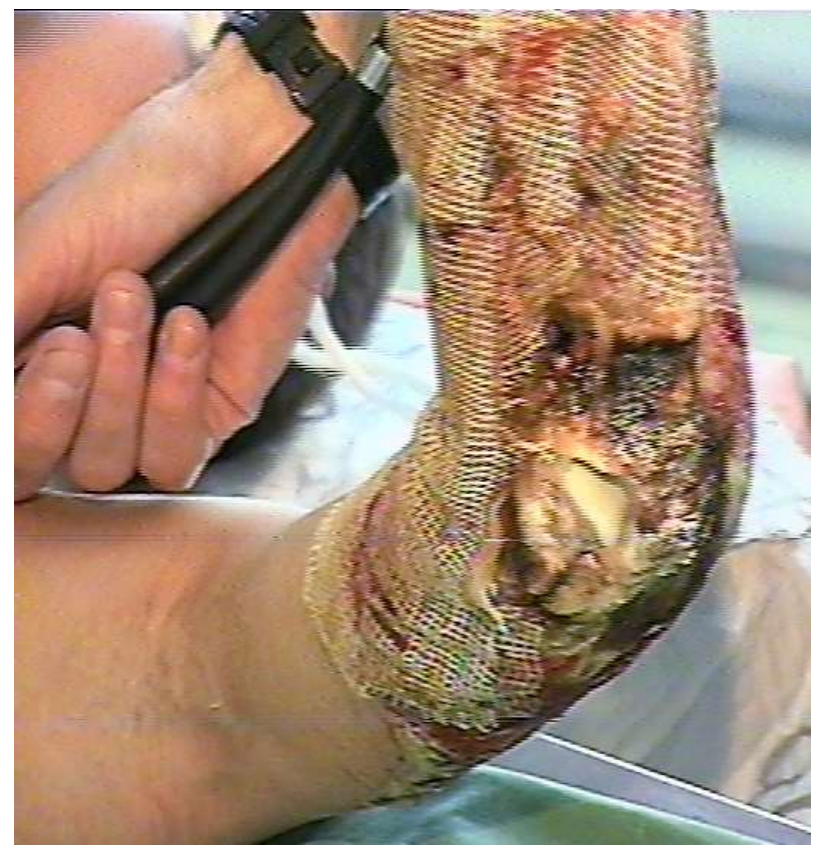

A

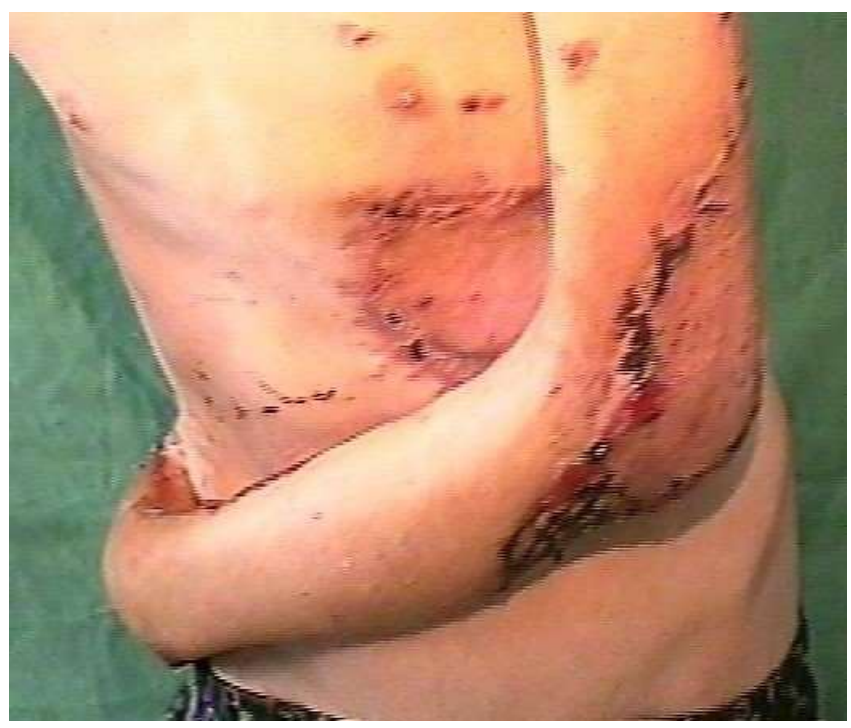

Б 


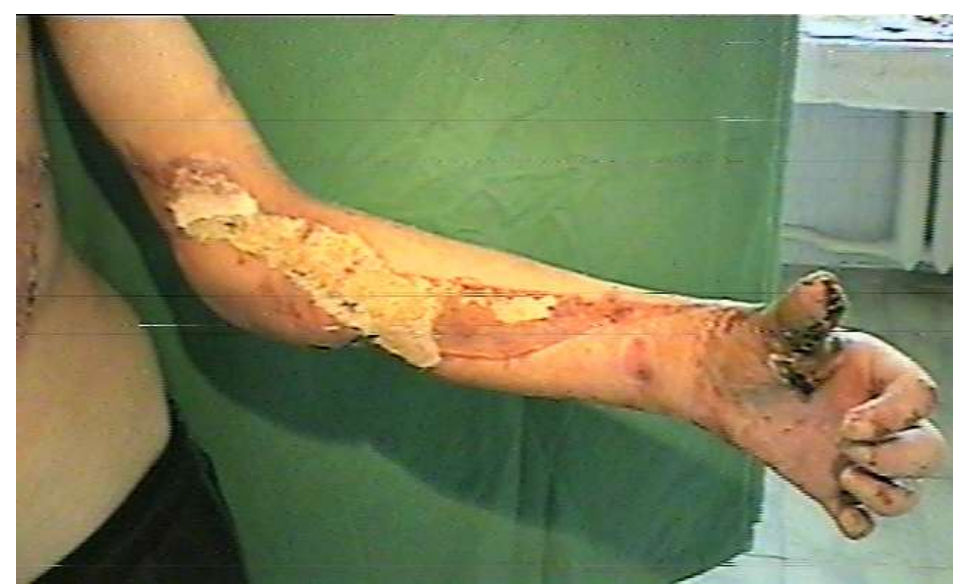

B

Рис. 25. Хворий С. (А) ураження високовольтним електричним струмом лівого ліктьового суглоба, передпліччя, кисті, з пошкодженням ліктьового суглоба та ліктьового нерва; (Б) пластика дефекту шкірнофасціальним торакоабдоміальним клаптем з живленням від задніх та середніх міжреберних та поперекових перфорантних систем; (В) після другого етапу пластики (6 тижнів після операції).

\subsubsection{2. Торакоабдомінальний клапоть на тимчасовій судинній} ніжці $з$ живленням від верхньої та нижньої поверхневих надчеревних артерій

Торакоабдомінальний клапоть отримує живлення від гілок верхньої та нижньої поверхневих надчеревних артерій. Формування клаптя здійснюється у напрямку від середньої пахвової лінії у напрямку середньої лінії передньої черевної стінки зверху і на 4 см донизу вздовж цієї лінії. Нижній край клаптя доходить до середньої ключичної лінії. Таким чином, основа клаптя розташовується у косому напрямку у середньо-нижній його ділянці. Розміри клаптів можуть складати від 16 см до 20-24 см.

Клінічний приклад. Хворий Ч., 43 років, поступив через 20 годин після травми з опіком полум'ям ІІАБ-ІІІ ступеня правої верхньої кінцівки, тулуба, обличчя 10\% поверхні тіла, різким порушенням кровообігу у кінцівці за змішаним типом. При об'єктивному дослідженні в ділянці задньо-внутрішньої поверхні правого плеча, ліктьового суглоба, передпліччя, не доходячи 5-6 см 
TRADITIONAL MEDICINE AND PHARMACOLOGY. ACHIEVEMENTS, INNOVATIONS, AND ALTERNATIVES

до променево-зап’ясткового суглоба - чорного кольору некротичний струп. Виражений набряк кисті, гра судин відсутня. Кисть синюшно-блідого кольору, пальці у положенні згинання у ПФС та МФС. Через 2 години після надходження проведені некротомії. На наступну добу призведено висічення некротичних тканин на задньо-внутрішній поверхні плеча, задньо-бічній поверхні ліктьового суглоба та циркулярно передпліччя 3 видаленням ліктьового згинача кисті, поверхневого і частини глибокого згинача пальців, ліктьового рогинача кисті, розсічення глибоких фасціально-м'язових футлярів правого передпліччя, карпального каналу, виділення судинно-нервових пучків. Через 2 доби здійснено видалення залишків некротичних тканин, а також резекцію дистального епіметафізу плечової та проксимального епіметафізу ліктьової та променевої кісток. Плечову кістку та кістки передпліччя фіксували трьома шпицями Ілізарова у положенні згинання $60^{\circ}$

На однойменній поверхні тулуба сформовано шкірно-фасціальний торакоабдомінальний клапоть 3 живленням від верхньої та нижньої поверхневих надчеревних артерій. Верхній розріз тканин здійснено від задньої пахвової лінії до середньої лінії живота в проекції 6-7 міжреберних проміжків. Задній край клаптя прямував донизу до середньої пахвової лінії і потім паралельно верхньому краю клаптя до рівня середньої ключичної лінії. Основа клаптя розташована у косому напрямку передньо-нижнього краю. Розміри клаптя склали $16 \mathrm{~cm} \mathrm{x} 24$ см. Після мобілізації клаптя донорську рану закрито вільним трансплантатом. Клапоть укладено на місце і фіксовано рідкими швами. Здійснено відстрочку клаптя. Через 10 діб проведено наступне втручання. Праву руку підведено до клаптя і фіксовано до передньої черевної стінки окремим швами-трималками і клапоть фіксовано до країв рани. Після приживлення клаптя через 4 тижні здійснено наступний етап по відсіченню живлячої ніжки і моделювання клаптя (рис. 32). 


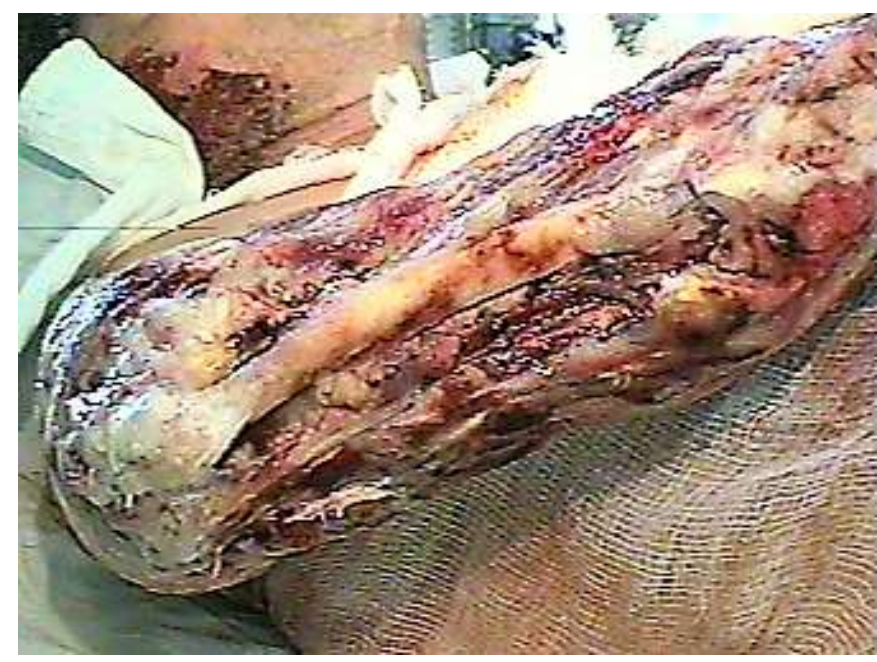

A

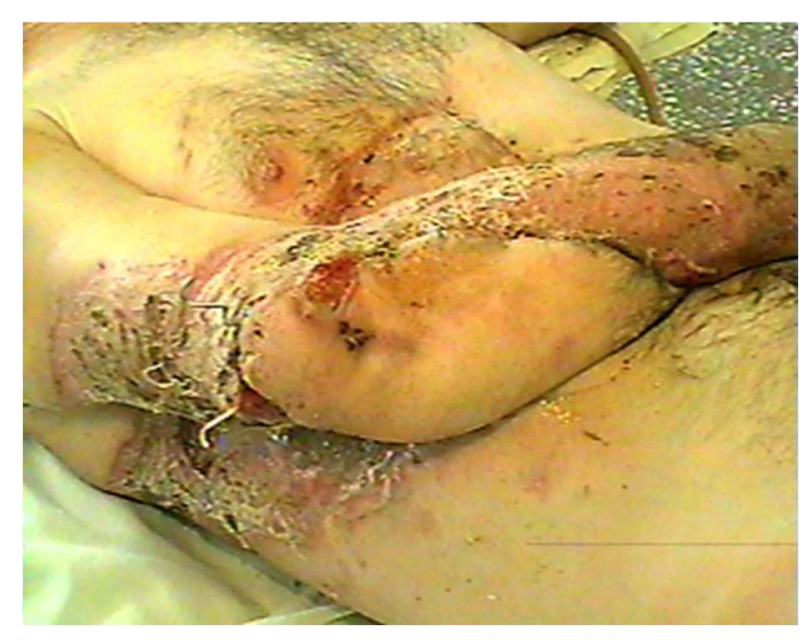

Б

Рис. 32. Хворий Ч. (А) опік полум'ям ІІАБ-ІІІ ступеня, тулуба, обличчя правої верхньої кінцівки 10\% поверхні тіла, різким порушенням кровообігу у кінцівці за змішаним типом, пошкодженням променевого нерва. Етапи видалення некрозу правого передпліччя та ліктьового суглоба. Сформовано відстрочений торакоабдоміальний клапоть; (Б) пластика дефекту шкірнофасціальним торакоабдоміальним клаптем з живленням від верхньої та нижньої поверхневих надчеревних артерій.

\subsubsection{3. Бічний клапоть грудної клітки на основі перфорантих} судин міжреберних артерій

Вперше перфорантні клапті міжреберних артерій були описані Kerrigan C.L.,Daniel R.K. у 1972 році [425].

У подальших роботах були описані анатомічні особливості перфорантних судин, що відгалужуються від міжреберних артерій [426-428].

Міжреберні перфорантні клапті застосовуються для пластики молочної залози, пахвової ямки, ліктьового суглоба та як вільні.

Розмітка клаптя здійснюється на бічній поверхні грудної клітки у проекції 5-8 міжреберних проміжків від лопаткової лінії до зовнішнього краю великого грудного м'яза - основи клаптя. Розсікається шкіра разом з глибокою фасцією двома паралельними розрізами над 5 та 9 ребрами. Розрізи на рівні 
TRADITIONAL MEDICINE AND PHARMACOLOGY. ACHIEVEMENTS, INNOVATIONS, AND ALTERNATIVES

лопаткової лінії з’єднуються і починається підняття клаптя у підфасціальному просторі зберігаючи судинні зв'язки між перфорасомами. Донорська ділянка частково ушивається, а частина, що залишилася, закривається вільним трансплантатом. Кінцівка підводиться рановою поверхнею до клаптя який підшивається до країв і фіксується пов'язками.

Клінічний приклад. Хворий П., 48 років отримав високовольтну травму електричним струмом обох верхніх кінцівок 10\% ПТ. Поступив 3 іншого лікувального закладу через 7 діб. У зв’язку з декомпенсацією кровообігу у правій верхній кінцівці здійснена атипова ампутація на рівні верхньої третини правого передпліччя. По зовнішній та задній поверхні лівого ліктьового суглоба та нижньої третини плеча відмічається місце вхіду електричної дуги у вигляді дефекту м'яких тканин 10 см х 16 см. Відмічається крайове запалення. Дно рани представлено капсулою ліктьового суглоба та окістям плечової кістки, фрагментами пошкоджених сухожиль. Все це покрито гнінофібринозним нальотом. Здійснена хірургічна обробка рани з видаленням гнійно-некротичних частин.

На бічній поверхні грудної клітки зліва здійснено формування шкірнофасціального клаптя на рівні 5-8 міжреберних проміжків розмірами 12 см х 18 см 3 включенням перфорантних судин міжреберних артерій. Донорська ділянка закрита вільними трансплантатами. Клапоть підшитий до рани i кінцівка фіксована пов'язками. Приживлення клаптя повне. Через 4 тижні здійснено другий етап - відсічення живлячої ніжки і моделювання клаптя на місці (рис. 33). 


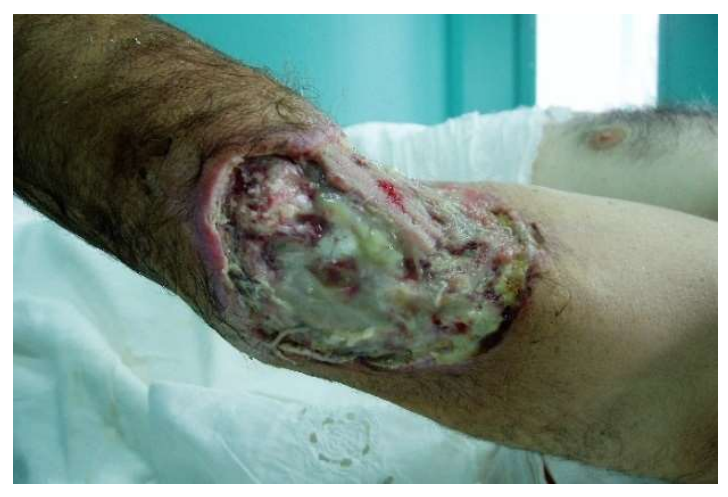

A

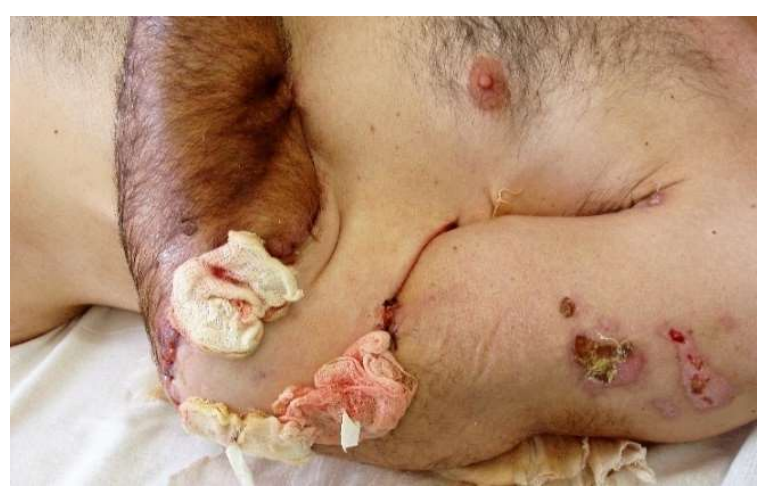

Б

Рис. 33. Хворий П. (А) гнійно-некротичний дефект м'яких тканин 10 см х 16 см; (Б) пластика дефекту бічним клаптем грудної клітки на основі перфорантих судин міжреберних артерій.

Бічний клапоть грудної клітки на основі перфорантих судин міжреберних артерій має добру васкуляризацію, що обумовлено постійними перфорантними судинами. Клапоть підходить за текстуральними властивостями для реконструкції великих дефектів ліктьового суглоба, передпліччя та плеча [429].

\subsection{4. Хірургічне лікування дефектів плеча та плечового суглоба.}

В структурі термічної травми ураження ділянки плечового суглоба виникають у 35-46\% постраждалих. Великі дефекти м'яких тканин, тривале запалення можуть призвести до порушень цілісності капсули з витіканням синовіальної рідини, пошкоджень ротаторної манжети плеча тощо. Для запобігання таких ускладнень дефект необхідно закривати повноцінними тканинами у ранні строки після травми. Пластика таких дефектів при дефіциті місцевих тканин у сполученні з пошкодженнями суглоба та кісток що його утворюють, являє дуже складну проблему і використовується увесь арсенал засобів для іiі вирішення.

\subsubsection{1. Клапті задньої поверхні грудної клітки}

\subsubsection{1. Шкірно-фасціальний білялопатковий клапоть}

Анатомічне обгрунтування та клінічне застосування клаптів, що формуються навколо лопатки вперше описали Combelles R. Et al (1975) [430, 
TRADITIONAL MEDICINE AND PHARMACOLOGY. ACHIEVEMENTS, INNOVATIONS, AND ALTERNATIVES

431]. У подальшому Gilbert A. M., Teot, L. У 1982 році запропонували вільні білялопаткові клапті [432].

Білялопатковий клапоть розташовується над лопаткою i може використовуватись в різних варіантах в залежності від судин які включаються у певний його вид. параскапулярний клапоть заснований на артерії, що огинає лопатку, яка є гілкою лопаткової артерії. Пройшовши крізь трикутний отвір артерія, що огинає лопатку розподіляється на поперечну та спадну шкірні гілки (рис. 34).

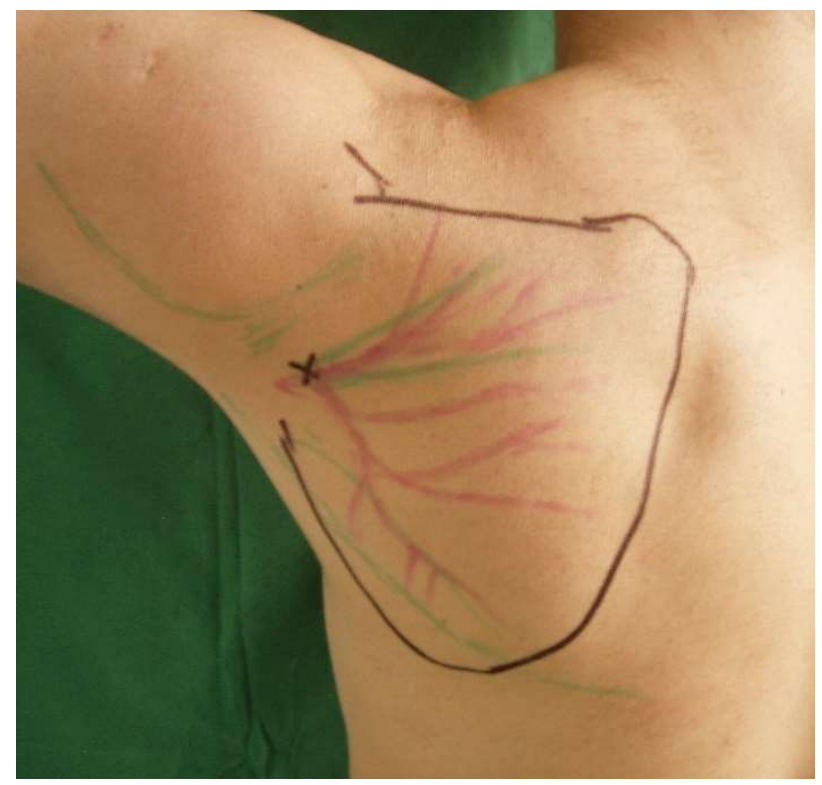

Рис. 34. Маркування білялопаткового клаптя

При заборі клаптя хворий лежить на протилежному боці з відведеною рукою. Розмічається трикутний отвір - місце виходу живлячої ніжки і точка ротації клаптя. В залежності від розмірів дефекту і методу ймовірного переміщення розмічуються контури клаптя.

Розріз шкіри та глибокої фасції здійснюється по попереднім розміткам. Дисекція клаптя здійснюється підфасціально 3 ретельною коагуляцією м'язових гілок від периферії у напрямку до трикутного отвору. Після формування клапоть розміщується на рановий дефект і фіксуюється швами. Донорська рана закривається вільним трансплантатом.

Клінічний приклад. Хвора 3., 48 років поступила через 2 тижні з іншого лікувального закладу з термомеханічною травмою плечового поясу справа. 
TRADITIONAL MEDICINE AND PHARMACOLOGY. ACHIEVEMENTS, INNOVATIONS, AND ALTERNATIVES

Виявлено великий дефект м'яких тканин в ділянках лівого надпліччя, плечового суглобу та плеча площею $3 \%$ ПТ. Рана по периферії покрита в'ялими грануляціями. На дні рани спостерігаються некроз ості лопатки, капсули плечового суглоба, ділянки некрозу над- та підосних м'язів та ділянки некрозу трапецевидного м’язу. На третій тиждень після травми здійснено видалення гнійно-некротичних тканин. по нижньому краю дефекту розсічена шкіра та власна фасція. Вертикальний розріз продовжений донизу і латерально. Клапоть відсепаровано до трикутного отвору де виходить артерія, що огинає лопатку. Навколо цієї точки ротації клапоть переміщено шляхом бічного ковзання і ротації під кутом $35^{0}$ на рановий дефект і фіксовано до його країв. Розміри клаптя склали 10 см х 19 см. Руку фіксовано у положенні відведення під кутом $40^{0}$. У післяопераційному періоді клапоть первинно прижив.

Через 4 тижні хвора поступила в клініку з хронічними виразками рубців, пошкодженням ротаторної манжети плеча, виразним больовим синдромом при рухах у суглобі. Здійснено висічення виразкових рубців, пластику даху плечового суглоба шкірно-м'язовим клаптем з НМС (найширшого м'яза спини).

Для покращення функції плечового суглоба здійснено його артродез за допомогою внутрішніх гвинтів та серкляжу, а також АЗФ (апарат зовнішньої фіксації) власної конструкції для компресії сегменту «плече-лопатка».

Післяопераційний період проходив без ускладнень. Через 4 тижні знятий АЗФ. Поступово рухи в кінцівці частково відновились завдяки включення м'язів плечового поясу (рис. 35). 
TRADITIONAL MEDICINE AND PHARMACOLOGY. ACHIEVEMENTS, INNOVATIONS, AND ALTERNATIVES

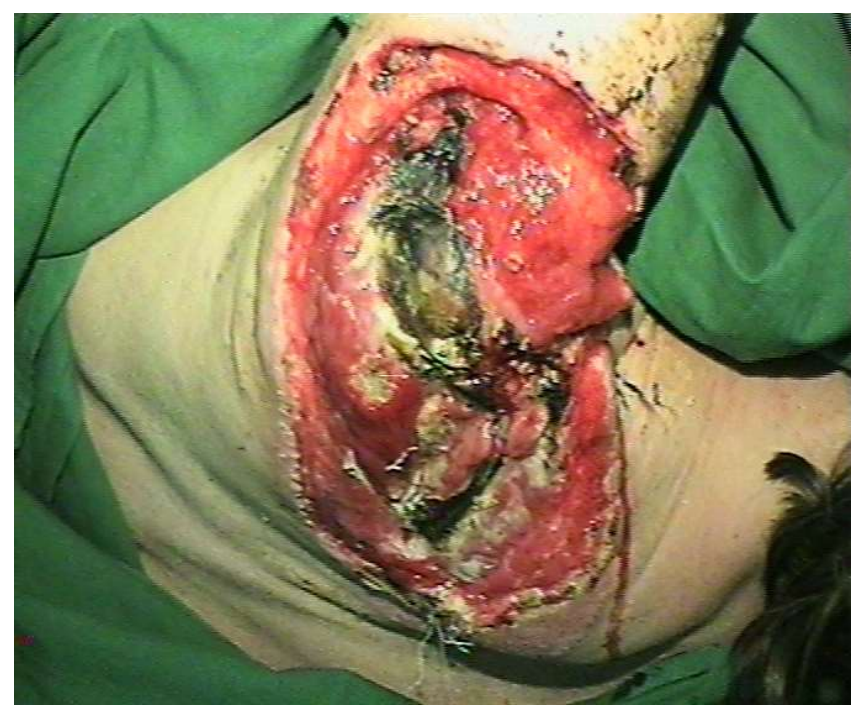

A

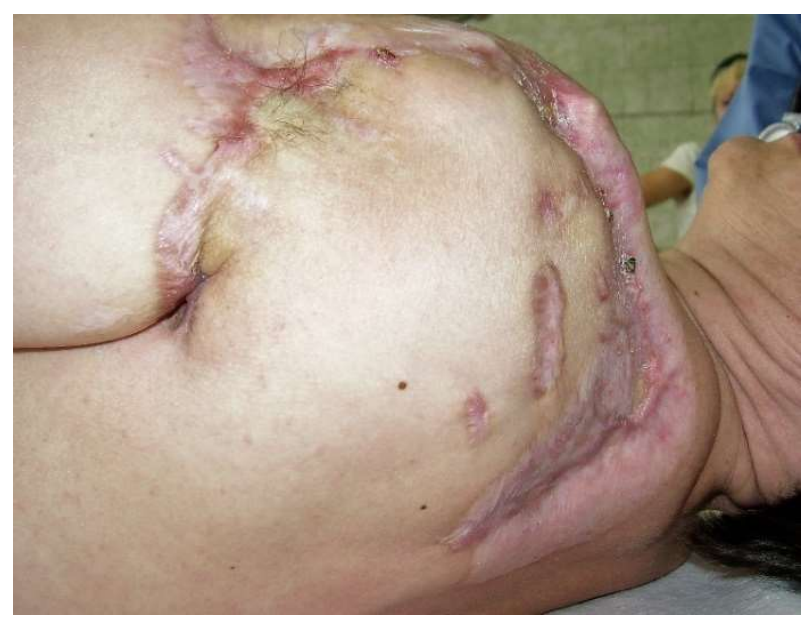

B

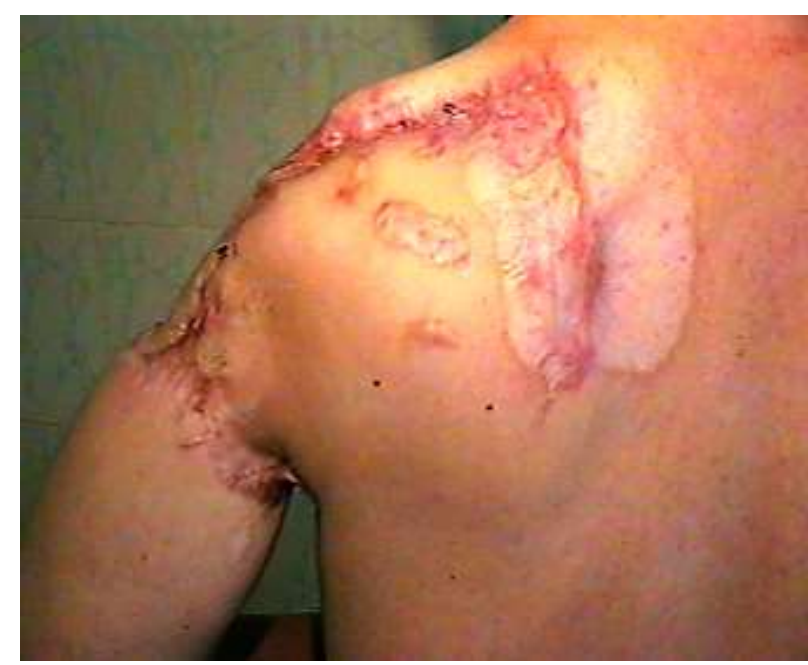

Б

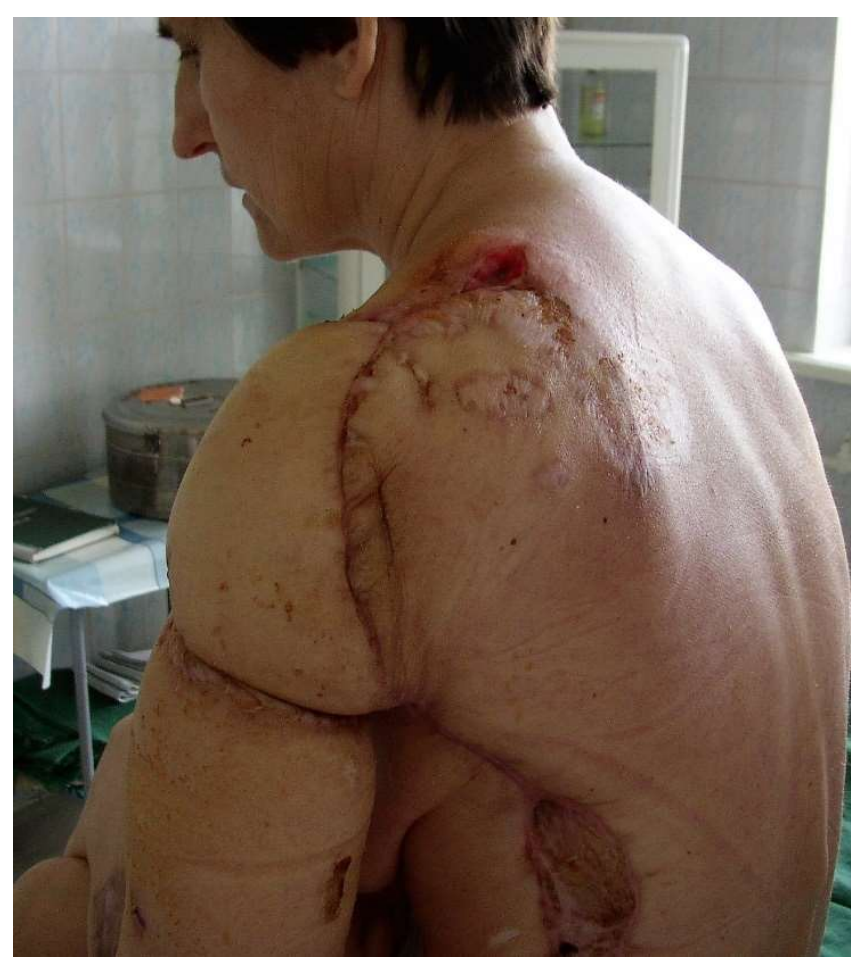

$\Gamma$

Рис. 35. (А) Хвора 3., 48 років, термомеханічна травма. Великий гнійно-некротичний дефект надпліччя, плечового суглобу та плеча 3 некрозом ості лопатки, капсули плечового суглоба, над- та підосних м’язів та трапецевидного м’язу; (Б) пластика дефекту лопатковим клаптем (4 тижні після пластики); (В) через 4 місяці після травми. Пошкодження ротаторної манжети, хронічні виразки рубців; (Г) пластика ділянки плечового суглоба шкірно-м’язовим клаптем НМС. 
TRADITIONAL MEDICINE AND PHARMACOLOGY. ACHIEVEMENTS, INNOVATIONS, AND ALTERNATIVES

Виявлено, що білялопатковий клапоть $є$ простим та надіним при пластиці складних дефектів навколо плечового суглоба. Можливість формування такого клаптя має вважатись ідеальним, оскільки він дає вигляд ідентичності тканин, не приносячи в жертву жодного м'яза і зменшуючи негативний вплив його відсутності.

Особливості клаптя у нашому випадку полягають у тому, що у клапоть були включені тканини, які розташовані нижче ості лопатки і включали як горизонтальну так і вертикальну судинні гілки артерії, що огинає лопатку. Для зменшення натягу живлячої ніжки ділянка шкіри над судинами не пересікалась. Такі прийоми дозволили сформувати клапоть великих розмірів і зберегти його життєздатність.

Переваги цього клаптя полягають у тому, що судинна ніжка постійна, має великий діаметр, що сприяє гарній перфузії тканин, а також виключається можливість порушень з боку опорно-рухового апарату.

\subsubsection{2. Шкірно-м'язовий клапоть 3 включенням найширшого} м'яза спини.

Вперше клапоть 3 включенням найширшого м'яза спини (HMC) був використаний Tanzini у 1906 році при пластиці дефекту грудної клітки після мастектомії (цит. за Quillen C.G. et al. (1978) [433]. Пізніше у 1970-90 роках використання цього клаптя було популяризовано для пластики дефектів в ділянках голови, шиї, верхніх кінцівок та як вільний клапоть при будь-яких локалізаціях ран [434-435].

НМС починається від нижніх шести грудних хребців, грудопоперекової фасції та гребня клубової кістки і зверху кріпиться до малого горбка плечової кістки. Домінантною судиною, що живить клапоть $є$ грудоспинна артерія (ГСА), що походить від артерії, що огинає лопатку. У задньо-нижніх відділах перфузію м'яза здійснюють перфорантні гілки поперекових артерій. Великі розміри клаптя до 25 см х 35 см дозволяють здійснювати закриття великих дефектів плечового поясу, плеча та ліктьового суглоба [436] (рис. 36). 
TRADITIONAL MEDICINE AND PHARMACOLOGY. ACHIEVEMENTS, INNOVATIONS, AND ALTERNATIVES

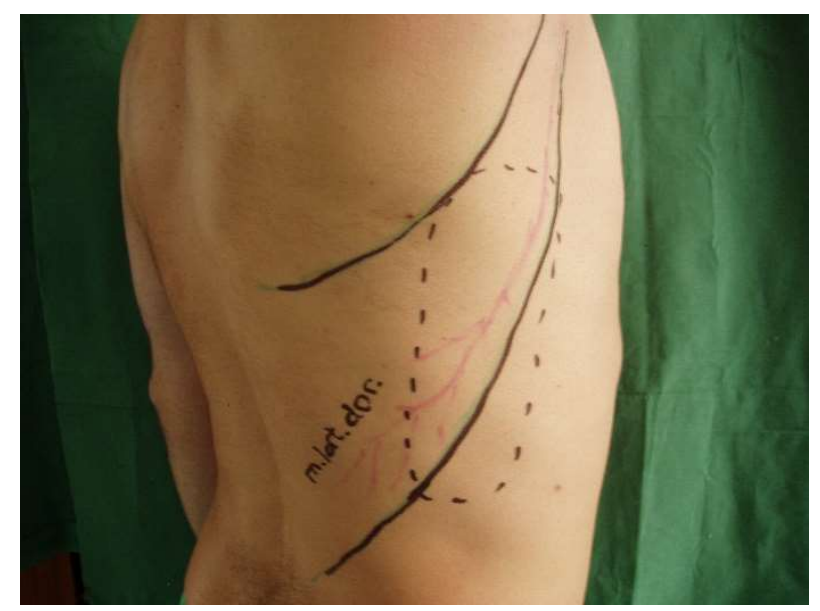

Рис. 36. Маркування шкірно-м’язового клаптя з включеннямНМС на грудоспинній ортерії.

Забір клаптя здійснюється у лежачому положенні на протилежному боці. Вісь клаптя проходить від заднього кута пахвової ямки до середньої точки гребня клубової кістки. Після маркування клапя на бічній поверхні грудної клітки розсікається шкіра та глибока фасція. Розріз починається від заднього кута пахвової ямки i продовжується вздовж зовнішнього краю НМС. Відводячи м'яз разом з покривними тканинами, ідентифікується грудоспинна артерія, яка знаходиться на внутрішній стороні м’яза. Виділяється грудоспинна артерія до місця її початку від артерії, що огинає лопатку. Біля відгалуження судини лігується артерія переднього зубчастого м’яза. У подальшому розріз шкіри, фасції та НМС здійснюється на одному рівні по наміченим контурам клаптя. Шкіра піднімається разом з м’язом, виділяючи його від нижче розташованих фасцій та ромбовидного м'яза.

Після формування шкірно-м’язового клаптя 3 НМС, від основи їі живлячої ніжки розсікаються тканини у напрямку до дефекту та створюється канал для судинної ніжки клаптя. При переміщенні клаптя на дефект в ділянки плечового суглоба чи плеча шкірно-м’язовий шар у основи ніжки можна не пересікати для запобігання ii натягу чи перекручування. Клапоть переміщується на дефект і фіксується швами донорська рана завширшки до 10 см ушивається первинно. Великий рановий дефект закривається вільними трансплантатами. 
TRADITIONAL MEDICINE AND PHARMACOLOGY. ACHIEVEMENTS, INNOVATIONS, AND ALTERNATIVES

Для збільшення площі закриття дефекту у клапоть разом з НМС включається передній зубчастий м'яз на своїй власні живлячій судині. Таким чином формується складний комплекс на єдиній грудоспинній артерії [437438].

Клінічний приклад. Хворий К., 17 років. Поступив в клініку з іншого лікувального закладу із скаргами на неможливість виконувати рухи у лівому плечовому суглобі. Травму - неповний відрив руки - отримав 6 місяців тому при падінні 3 мотоцикла. При об'єктивному дослідженні відмічається деформація контурів лівого плечового суглоба, плеча. Покривні тканини рубцево змінені, на окремих ділянках присутні виразки та нориці з серозногнійними виділеннями. Активні рухи у лівому плечовому суглобі відсутні. Для покращення функції плечового суглоба вирішено здійснити видалення змінених тканин ураженої ділянки, пластику дефекту шкірно-м'язовим клаптем з НМС та артродезування плечового суглоба.

При хірургічному втручанні здійснено видалення тканин ділянки лівого плечового суглоба та проксимального відділу плеча. При ревізії суглоба виявлен відсутність голівки плечової кістки, кісткові фрагменти з гнійними вогнищами розташованими у щільній рубцевій тканині, дистальна частина плечової кістки має вигляд бурульки. Здійснено висічення фібрознонекротичних ділянок, видалено кісткові секвестри плечової кістки, видалена суглобова сумка, зв'язки плечового суглоба та суглобовий хрящ, а також проведено резекцію дистальної частини плечової кістки. Таким чином утворився кістковий дефект проксимальної частини плечової кістки довжиною 8см. Для закриття дефекту, що утворився сформовано шкірном'язовий клапоть з НMC розміром 15 см х 25 см, який підведено знизу до дефекту. Для заміщення кісткового дефекту взято кістковий трансплантат із середньої третини малої гомілкової кістки лівої гомілки довжиною 10 см. Трансплантат укладений в ділянку кісткового дефекту. Для фіксації плеча $\mathrm{i}$ кісткового фрагменту накладено АЗФ. Крізь трансплантат та середню третину плечової кістки проведено по 2 стрижні. Також 3 стрижні проведено крізь 
TRADITIONAL MEDICINE AND PHARMACOLOGY. ACHIEVEMENTS, INNOVATIONS, AND ALTERNATIVES

акроміальний відросток та ость лопатки. Всі стрижні фіксовані між собою за допомогою півкілець та з'єднувальних стрижнів у положенні відведення плеча під кутом $30^{\circ}$. Шкірно-м'язовий клапоть 3 НМС підшитий до країв рани. Післяопераційний період проходив без ускладнень. Клапоть прижив, трансплантат добре зафіксував плече до лопатки. АЗФ знято через 2,5 місяці і хворого направлено на реабілітацію (рис. 37).

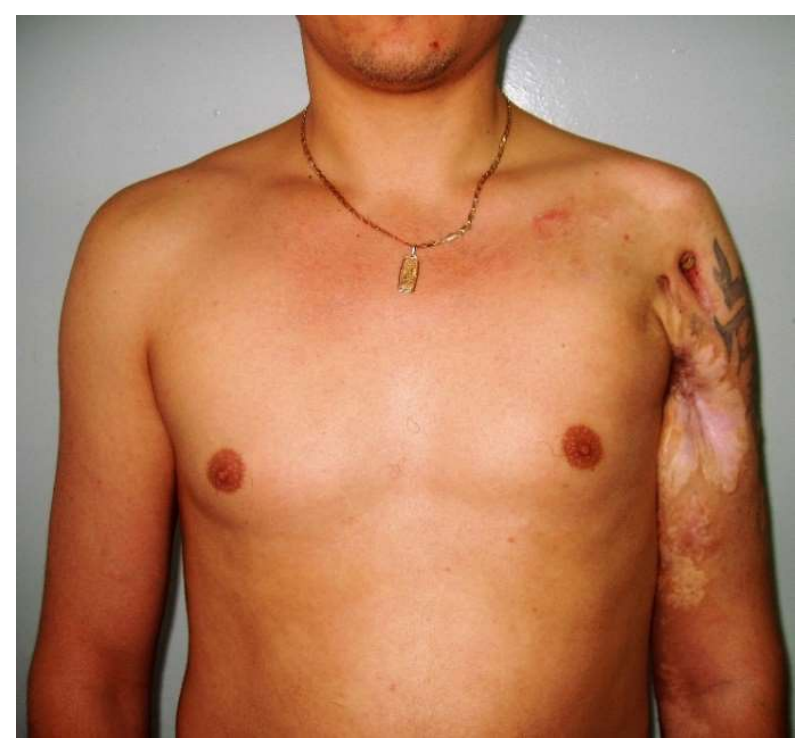

A

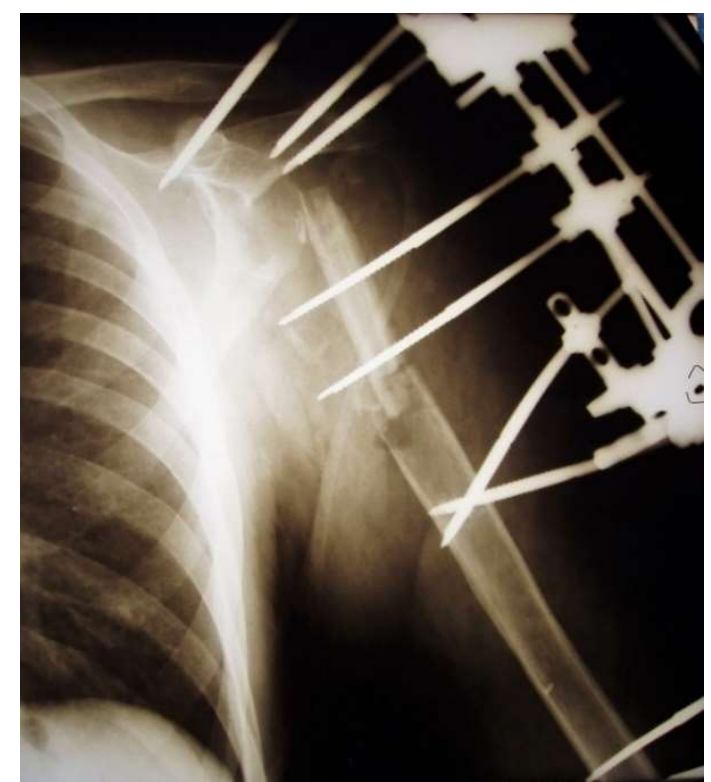

B

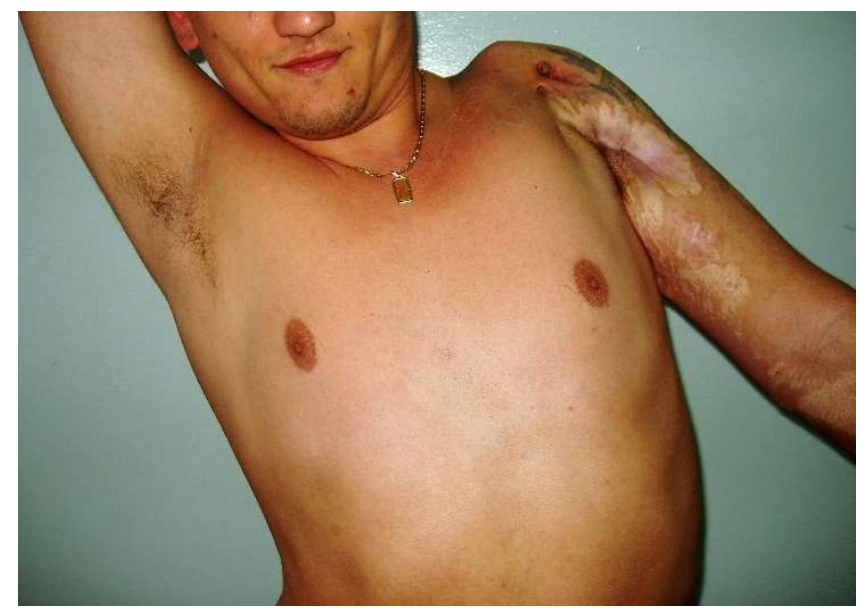

Б

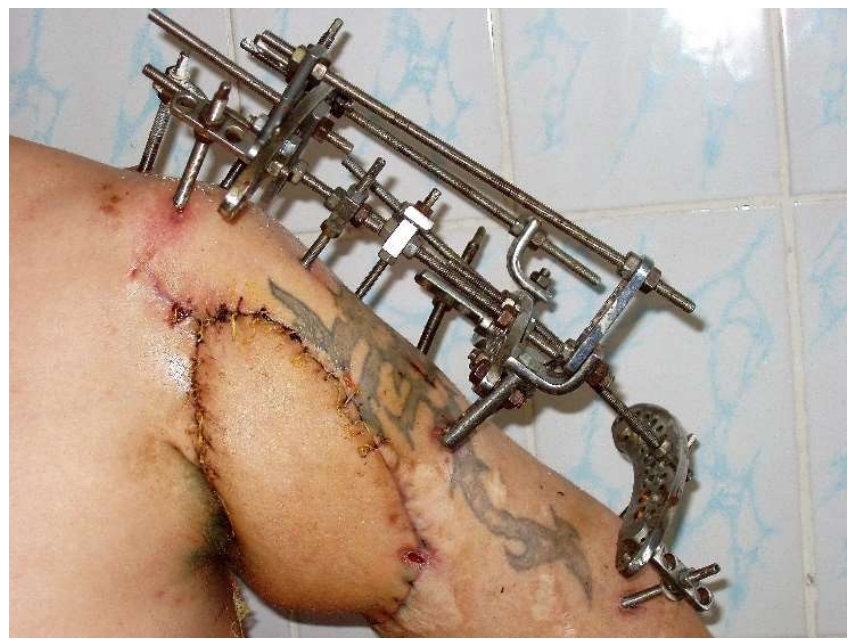

$\Gamma$

Рис. 37 (А, Б) Хворий К., 17 років, деформація контурів лівого плечового суглоба, плеча. Активні рухи у лівому плечовому суглобі відсутні;

(В) пластика дефекту шкірно-м'язовим клаптем НМС, накладання АЗФ; (Г) кісткова пластика проксимального відділу плечової кістки, АЗФ. 
TRADITIONAL MEDICINE AND PHARMACOLOGY. ACHIEVEMENTS, INNOVATIONS, AND ALTERNATIVES

Клінічний приклад. Хворий Т., 18 років, учень. Поступив у клініку по переводу з іншого лікувального закладу через 27 діб з діагнозом: загальна високовольтна електротравма, опік електричним струмом IIАБ - III ступеня лівого надпліччя, плечового суглоба, плеча, гнійно - некротичний дефект області лівого плечового суглоба, плеча, пошкодження променевого нерва лівої верхньої кінцівки, ампутаційна кукса правого плеча у верхній третині.

Об'єктивно в області лівого плечового суглоба, верхньої та середньої третини лівого плеча визначається дефект покривних тканин, дельтоподібного м'язу на 3/4 об’єму окружності, верхньої та середньої третин триголового та двоголового м'язів плеча. На плечовій кістці у проксимальній третині відсутні м'які тканини, ця ділянка має сіро-коричневий колір. На передній поверхні плеча $\epsilon$ шкірно-м'язовий місток в якому проходить судинно-нервовий пучок. Активні рухи в плечовому і ліктьовому суглобах відсутні. Відзначається «висяча кисть» з відсутністю розгинання у променево-зап'ястковому суглобі суглобах кисті і пальців; в зазначених суглобах можливі згинання у невеликому об'ємі. Втрата чутливості на тилі передпліччя, кисті, 4 i 5 пальцях. Кровообіг в дистальних відділах кінцівки збережено. На торці кукси верхньої третини правого плеча $є$ некроз м'язів; в рану підлягає коричневого кольору кукса плечової кістки 5 см завдовжки 3 ділянками грануляції. Після передопераційної підготовки здійснена остеонекректомія дистального відділу акроміального відростка лівої лопатки, фрезерування кістково - мозкового каналу лівої плечової кістки в проксимальній третини, пластика дефекту плечового суглоба і плеча складним шкірно-м'язовим клаптем з $\mathrm{HMC}$ розміром $18 \mathrm{~cm} \mathrm{х} 32 \mathrm{~cm}$ та клаптем переднього зубчастого м'яза розміром $8 \mathrm{~cm}$ х 16 см на одній живильній ніжці.

У зв'язку з загрозою можливого кровотечі з кукси правої плечової артерії, зроблена перев'язка правої підключичної артерії i вени та нетипову реампутацію правого плеча по типу некректомії. В післяопераційному періоді пересаджені клапті частково прижили. Однак, через 9 діб після хірургічного втручання при струсі хворого під час транспортування відбувся вивих голівки 
TRADITIONAL MEDICINE AND PHARMACOLOGY. ACHIEVEMENTS, INNOVATIONS, AND ALTERNATIVES

лівої плечової кістки. Виникла загроза пошкодження судинно-нервового пучка. Для збереження кінцівки здійснено хірургічне втручання. Під час ревізії виявлений повний вивих лівого плеча, голівка i проксимальна ділянка плечової кістки довжиною близько 8 см некротизовані. Проведена резекція некротизованої частини проксимальної третини плечової кістки, видалені нежиттєздатні ділянки суглобової западини лопатки та частина акроміального відростка. Дистальний фрагмент плечової кістки занурений у суглобову западину лопатки. Здійснено фіксація сегмента «лопатка-плече» спице стрижневим АЗФ. Для цього проведено 3 стрижні крізь ость та акроміальний відросток лопатки які з'єднано півкільцем, а також у середній та дистальній третинах плеча проведено по 2 стрижні які з'єднано півкільцями. Півкільця лопатки та плеча жорстко з'єднано між собою у відведенні плеча під кутом $25^{\circ}$. За рахунок анатомічного укорочення плеча, раніше пересадженими клаптями вдалося повністю закрити дефект м'яких тканин. Післяопераційний період протікав гладко. Проводилась інфузійно-трансфузійна, антибактеріальна, протизапальна, симптоматична терапія. Через 3 та 7 діб остаточі рани закрито вільними трансплантатами. Після приживлення клаптів і трансплантатів хворий виписаний за місцем проживання. Повторно поступив через 2 місяці. Рентгенологічно і клінічно відзначалася консолідація лівого плеча і лопатки. Проведений демонтаж апарату зовнішньої фіксації. Пацієнт в задовільному стані направлений для проведення медико - соціальної реабілітації (рис.38).

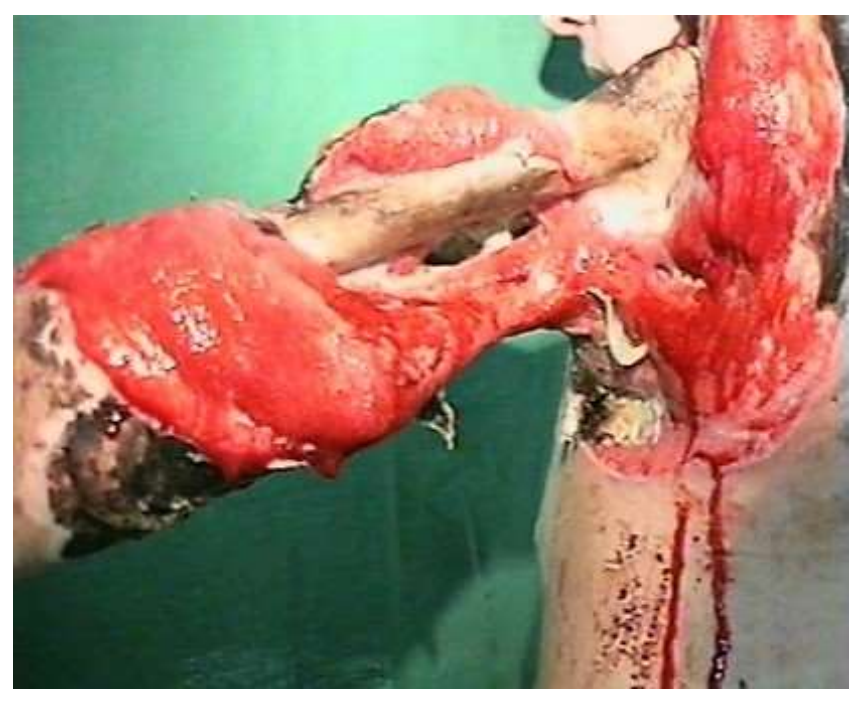

A

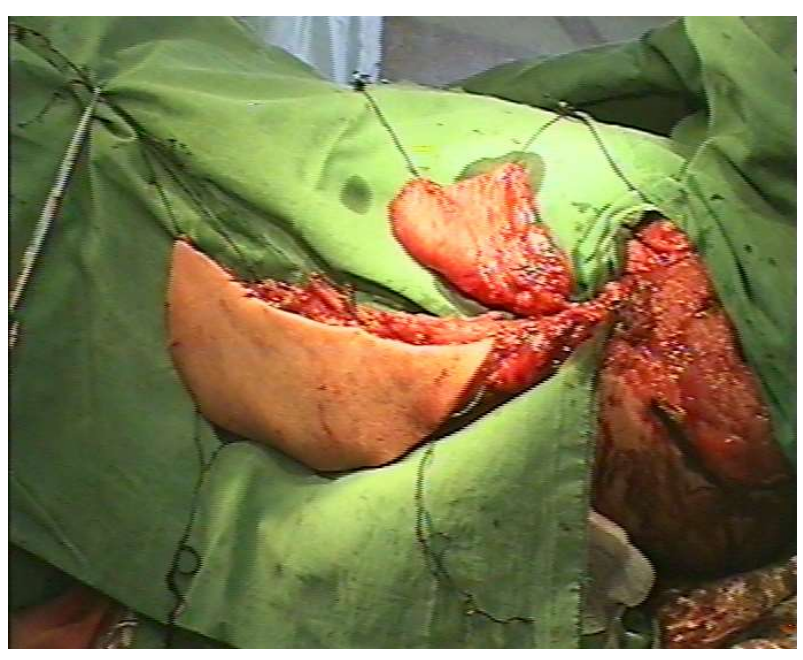

Б 


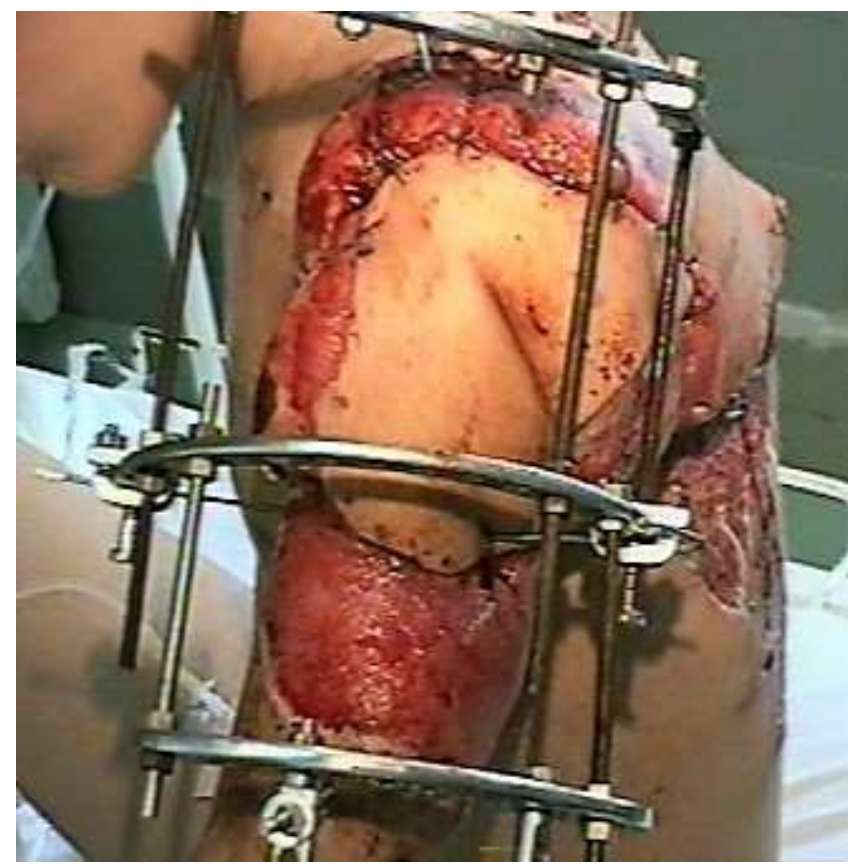

$\mathrm{B}$

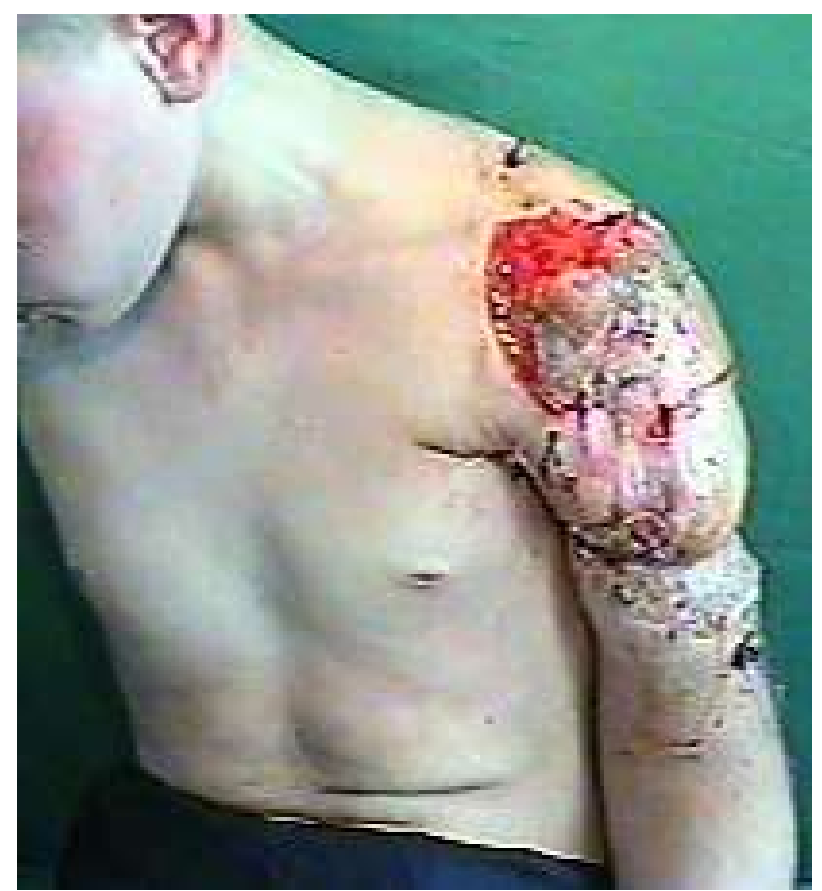

$\Gamma$

Рис. 38. Хворий Т. (А) загальна високовольтна електротравма, опік електричним струмом ІІАБ - III ступеня лівого надпліччя, плечового суглоба, плеча, гнійно - некротичний дефект області лівого плечового суглоба, плеча; (Б) сформований шкірно-м'язовий клапоть з НМС та м'язовий 3 переднього зубчастого м’яза на одній судинній ніжці; (B) резекція некротизованої частини проксимальної третини плечової кістки, видалені нежиттєздатні ділянки суглобової западини лопатки та частина акроміального відростка. Фіксація сегмента «лопатка-плече» спице - стрижневим АЗФ; (Г) через 1 місяць після лікування.

\section{Перфорантні клапті грудоспинної артерії}

\subsubsection{3. Бічний шкірно-фасціальний клапоть грудної клітки}

Бічний шкірно-фасціальний клапоть грудної клітки (БКГК) на бічній артерії грудної клітки (БАГК) вперше описав Coninck et al. у 1976 році (цит. за Prasad N.N. et al. [438].

БКГК безпечно формується на бічній поверхні грудної клітки через його гарну васкуляризацію. Анатомічна територія БАГК була представлена в роботах Manchot та Salmon [ цит. за Wei F.Ch., Mardini S. [436], а динамічний аспект судинної ділянки визначив Nakajima H. et al. [389]. 3 робіт дослідників відомо, що завдяки ГСА, яка розташована позаду БАГК та гілок грудо- 
TRADITIONAL MEDICINE AND PHARMACOLOGY. ACHIEVEMENTS, INNOVATIONS, AND ALTERNATIVES

акроміальної артерії (ГАА) попереду, у бічному регіоні грудної клітки дуже багата васкуляризація і існує можливість формування клаптів на різних прилеглих судинах.

БКГК розташований між краями великого грудного м'язу (ВГМ) та НМС. БАГК відгалужується безпосередньо від пахвової артерії і після подачі м'язових гілок до грудного та переднього зубчастого м'язів, виходить на бічну грудну фасцію, що покриває передній зубчастий м’яз та зовнішній косий м'яз живота. Лежачи поверхнево на цій фасції, артерія віддає 3-4 перфорантних гілки, що живлять шкіру цього регіону (рис. 39).

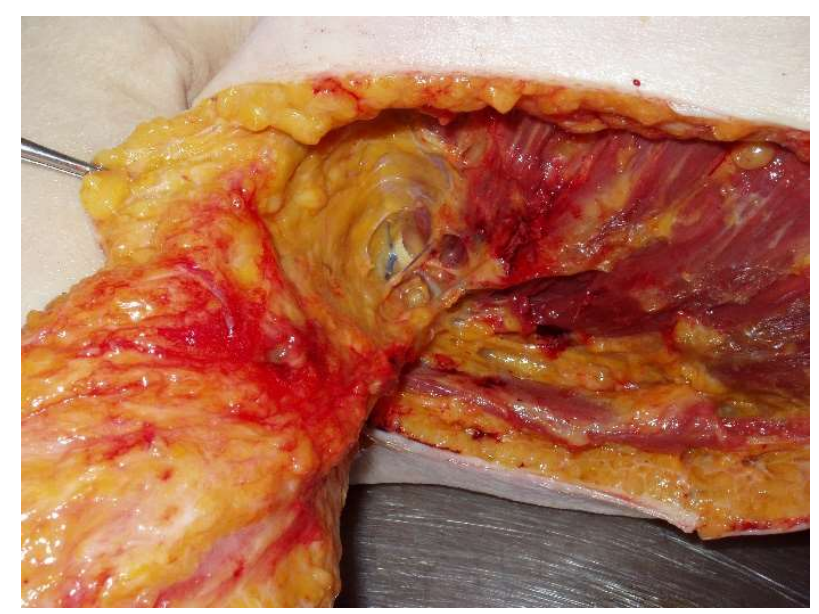

Рис. 39. Формування бічного клаптя грудної клітки.

Маркування клаптя здійснюється в ділянці між ВГМ та НМС. Верхня межа знаходиться на рівні 4 ребра. Довжина клаптя може сягати 25 см у каудальному напрямку. Розріз шкіри та фасції здійснюється по передній, задній та нижній межам. Підняття клаптя виконується доверху під грудною фасцією для збереження надфасціальної судинної сітки. У верхньому відділі клаптя розрізається тільки шкіра і визначається БАГК. Потім підшкірна клітковина і фасція досікається до судинної ніжки. Від судинної ніжки розріз шкіри з клітковиною продовжується у напрямку пахвової ямки і далі до місця дефекту. Формується підшкірний канал для судинної ніжки i клапоть укладається на місце дефекту. Донорська ділянка у більшості випадків закривається вільними трансплантатами. 
TRADITIONAL MEDICINE AND PHARMACOLOGY. ACHIEVEMENTS, INNOVATIONS, AND ALTERNATIVES

Клінічний приклад. Той же хворий, що й на рис. Через 2 роки пацієнт поступив 3 вогнищевим остеомієлітом правої плечової кістки привідною контрактурою правого плеча. здійснено обробка некротичних ділянок плечової кістки, видалені невеликі кісткові секвестри. Здійснено пластику дефекту шкірно-фасціальним клаптем на бічній артерії грудної клітки. Розмір клаптя склав 15 см х 23 см. Приживлення клаптя повне (рис. 40).

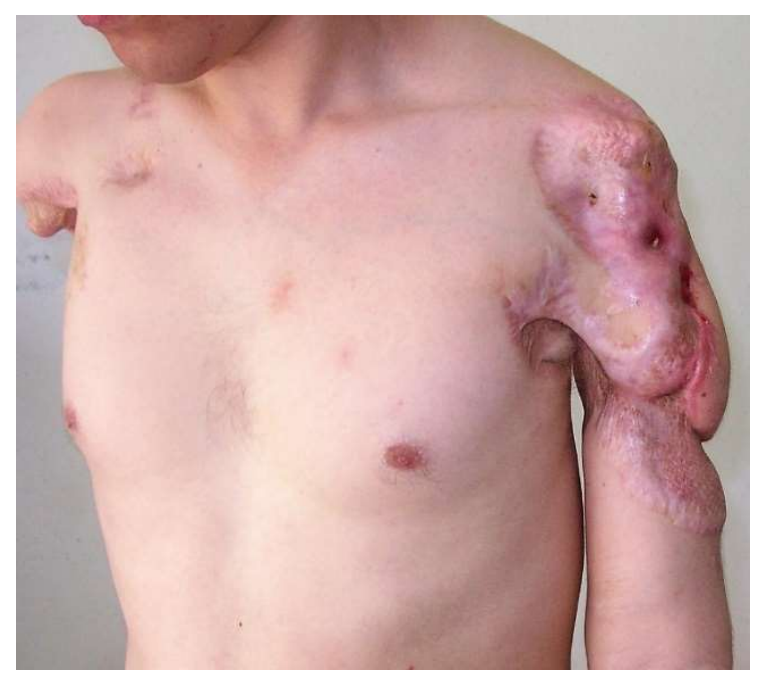

A

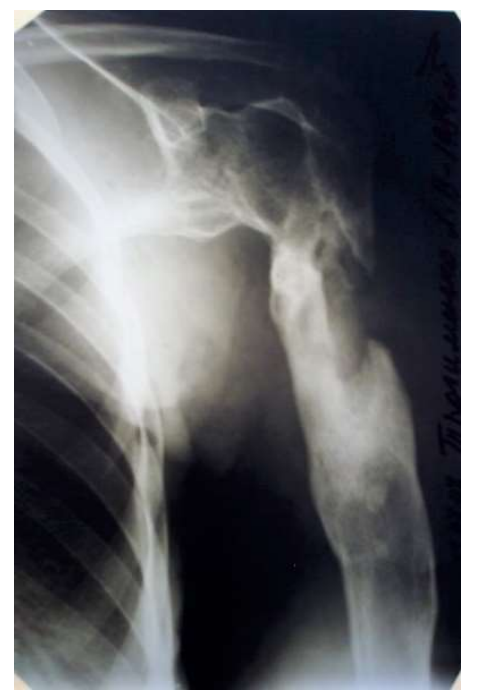

$\mathrm{B}$

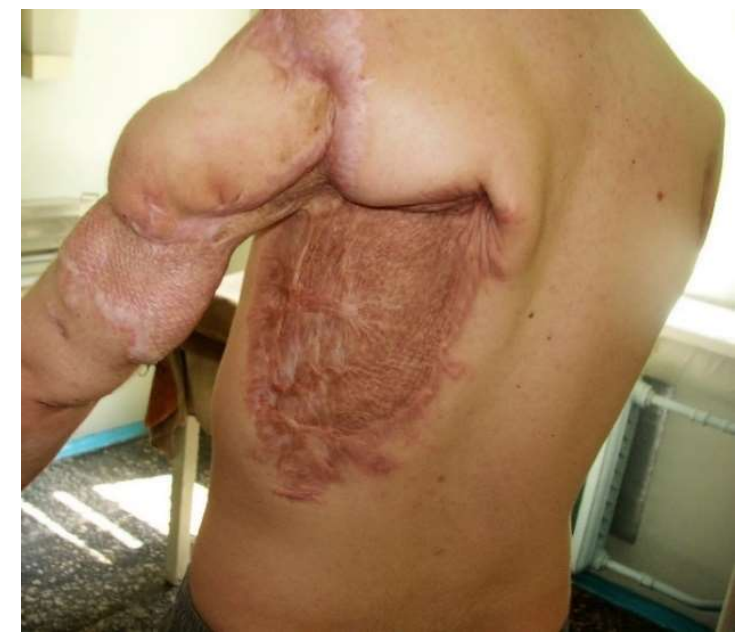

Б

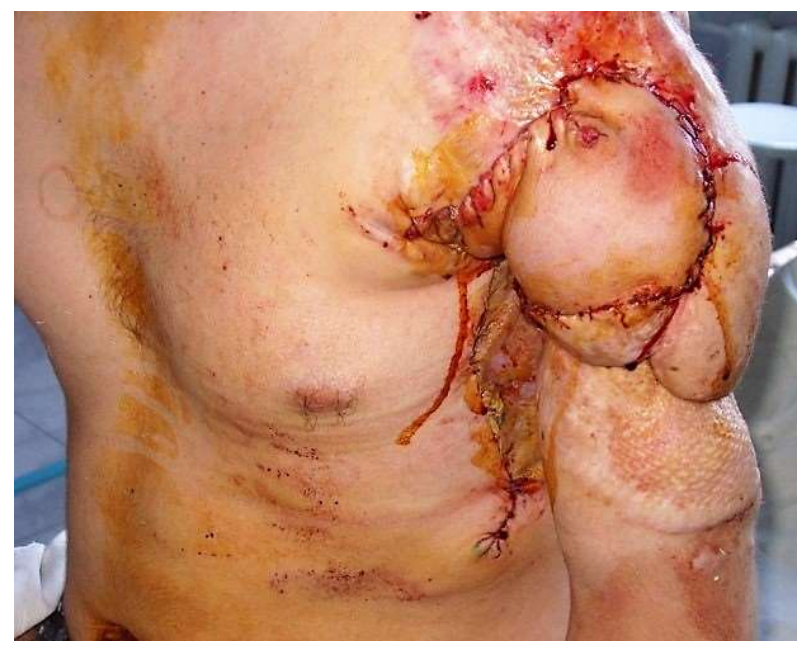

$\Gamma$

Рис. 40. Хворий Т., 20 років. (А, Б) вогнищевий остеомієліт правої плечової кістки, привідна контрактура правого плеча; (В) на рентгенограмі визначаються явища вогнищевого остеомієліту правої плечової кістки; (Г) санація гнійного вогнища плечової кістки, пластика дефекту шкірнофасціальним клаптем на бічній артерії грудної клітки. 
TRADITIONAL MEDICINE AND PHARMACOLOGY. ACHIEVEMENTS, INNOVATIONS, AND ALTERNATIVES

\subsection{5. Аналіз хірургічного лікування хворих 3 глибокими} термічними та травматичними дефектами верхніх кінцівок

Результати хірургічного лікування постраждалих 3 термічними ураженнями верхніх кінцівок були вивчені і проаналізовані у найближчий та віддалений періоди в строки від 3 місяців до 8 років.

\subsubsection{1. Найближчі результати хірургічного лікування}

Основними критеріями оцінки найближчих результатів хірургічного лікування хворих були характер та ступінь приживлення клаптів. Оцінку результатів здійснювали відносно можливостей подальшого функціонального лікування й необхідності повторних оперативних втручань (табл. 2).

Таблиця 2.

\section{Узагальнені результати оцінки госння ран з глибокими}

термічними та травматичними дефектами верхніх кінцівок

\begin{tabular}{|c|c|c|c|c|c|c|c|c|c|}
\hline \multirow{3}{*}{$\begin{array}{l}\text { Кількі } \\
\text { сть } \\
\text { пацієн } \\
\text { тів }\end{array}$} & \multirow{3}{*}{$\begin{array}{l}\text { Кількість } \\
\text { втручань }\end{array}$} & \multicolumn{8}{|c|}{ Результати } \\
\hline & & \multicolumn{2}{|c|}{ первинно } & \multicolumn{2}{|c|}{$\begin{array}{c}\text { частковий } \\
\text { некроз }\end{array}$} & \multicolumn{2}{|c|}{$\begin{array}{l}\text { повний } \\
\text { некроз }\end{array}$} & \multicolumn{2}{|c|}{ нагноєння } \\
\hline & & Абс. & $\%$ & Абс. & $\%$ & Абс. & $\%$ & Абс. & $\%$ \\
\hline 93 & 121 & 83 & 68,6 & 10 & 8,5 & 2 & 1,6 & 26 & 21,3 \\
\hline
\end{tabular}

Із даних дослідження визначено, що ступінь приживлення клаптів відбувається за рахунок раннього видалення некротизованих тканин, що значно зменшує запалення та зберігає васкуляризацію ранового ложа. Слід відмітити, що добре приживлення та меншу кількість ускладнень спостерігали при використанні васкуляризованих клаптів.

Ускладнення, що виникли у післяопераційному періоді розділили на ранні та пізні. До ранніх ускладнень віднесли повний або частковий некрози клаптів, нагноєння післяопераційної рани. Причиною ранніх ускладнень були артеріальна та(чи) венозна недостатність клаптів, місцеві запальні реакції. До пізніх віднесли ускладнення, які виникли у більш пізньому періоді і проявлялись рубцевим блоком сухожиль i нервів, що перешкоджало 
TRADITIONAL MEDICINE AND PHARMACOLOGY. ACHIEVEMENTS, INNOVATIONS, AND ALTERNATIVES

відновленню функції суглобів кінцівки, рубцевою трансформацією трансплантатів, лігатурними норицями, нейро-дистрофічними проявами.

Нагноєння клаптів виникало внаслідок неповного видалення некротичних тканин та некрозу тканин, що перебували у парабіотичному стані, а також виникненням місцевих запальних реакцій, наявністю фіброзного шару на дні рани та поганим іiї кровообігом.

В одному випадку повний некроз клаптів виник у ранній післяопераційний період після першого етапу пластики дефекту кисті i променево-зап'ясткового суглоба паховим клаптем внаслідок тромбозу судин живлячої ніжки та критичного порушення кровообігу.

У другому випадку повний некроз трикутних клаптів виник після пластики дефекту м'яких тканин на ліктьовій поверхні 1 пальця внаслідок низьковольтної електротравми. У даному спостереженні формування трикутників здійснювалось в умовах місцевої запальної реакції і дно рани було представлено слабо васкуляризованими тканинами.

Часткові некрози переміщених клаптів обмежувались ураженням тільки поверхневих шарів дерми, що не потребувало виконання додаткової пластики. В 1 випадку після висічення частини некрозу рану закрили дерматомним трансплантатом (рис. 41).

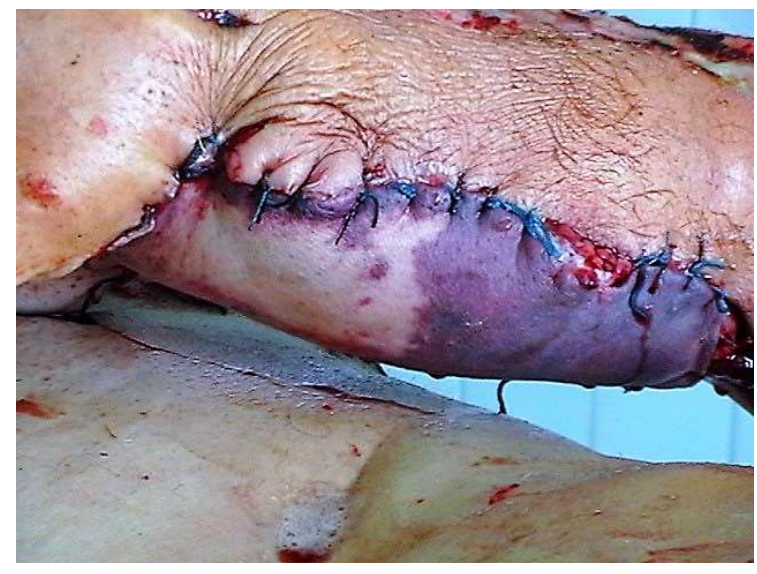

A

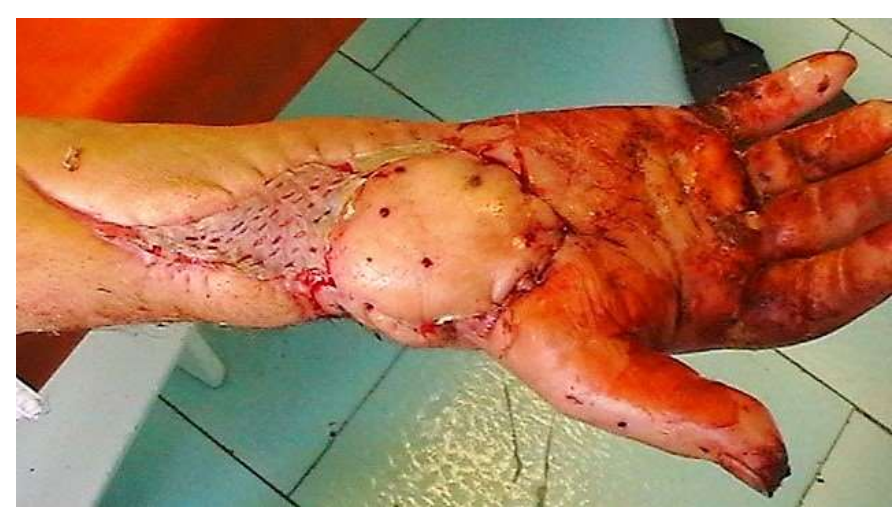

Б

Рис. 41. (А) Хворий Х., частковий некроз дистального відділу пахового клаптя після пластики волярної поверхні нижньої третини передпліччя та кисті; (Б) висічення некрозу фрагменту пахового клаптя та вільна шкірна пластика. 
TRADITIONAL MEDICINE AND PHARMACOLOGY. ACHIEVEMENTS, INNOVATIONS, AND ALTERNATIVES

Пізні ускладнення виникли у 14(11,6\%) випадках. Вони проявлялись у вигляді

рубцевих блоків сухожиль згиначів (4) разом з втягненням нервових стовбурів у рубцевий процес та розгиначів 2-4 пальців (6). У 4 випадках спостерігалась неврологічна симптоматика у вигляді болю, гіпо чи парастезій, випадіння рухів м'язів. Проведенням консервативної терапії неврологічні прояви вдалось усунути.

При виконанні пластичного закриття долонних (1) та тильних (4) дефектів кисті та пальців клаптями з торакоабдомінальної зони на тимчасовій судинній ніжці трьом хворим віком після 45 років, розвинувся нейродистрфічний синдром. Він відзначався вираженим набряком кисті і пальців особливо їх тильних поверхонь, тривалими больовими явищами, зблідненням чи посинінням шкіри сегменту, тугорухомістю суглобів пальців. Такі явища дуже важко піддавались консервативному лікуванню і спостерігались на протязі декількох років.

Як показує аналіз результатів лікування хворих з глибокими термічними та травматичними дефектами верхніх кінцівок частота розвитку як інфекціоно-гнійних, так і некротичних ускладнень суттєво нижчі у пацієнтів у яких були відсутні або мало виражені первинні місцеві запальні реакції, що пов'язано з раннім видаленням некротичних тканин. Ступінь приживлення клаптів та частота ускладнень залежала від ступеня кровообігу дна ранових дефектів та клаптів, що використовувались.

Зменшення кількості ускладнень пов'язано з більшою стійкістю клаптів 3 осьовим кровообігом до інфекційного процесу, надійності кровообігу, що забезпечує їх більшу життєздатність.

2.6.5.2. Віддалені результати хірургічного лікування хворих 3 глибокими термічними та травматичними дефектами верхніх кінцівок

Оцінку віддалених результатів лікування проводили на основі двох критеріїв - адекватність відновлення покривних тканин і відновлення функції сегмента чи кінцівки: 
TRADITIONAL MEDICINE AND PHARMACOLOGY. ACHIEVEMENTS, INNOVATIONS, AND ALTERNATIVES

- $\quad$ добрий - адекватні покривні тканини, клапті набували природний колір, відновлювалась чутливість, вони ставали рухливими. Функція кінцівки відновлювалась повністю чи відмічалась втрата функції до 10\%;

- задовільний - клапті гіпо- чи гіперпігментовані, рубцево змінені краї, нерівна поверхня, фіксація до рухливих утворень сегмента з обмеженням його рухів, часткове відновлення чутливісті. Втрата функції сегментів кінцівки до 50\%;

- незадовільний - більше 50\% пересаджених клаптів рубцево змінені, їх краї щільно фіксовані до рухливих глибоких утворень, клапті місцями мають виразкові рани. Порушення функції кінцівки більше ніж на 50\%.

Віддалені результати лікування постраждалих з глибокими термічними та травматичними дефектами верхніх кінцівок вивчені у 57(61,3\%) хворих (табл. 3), (рис. $42-45)$.

Таблиця 4.

Віддалені результати лікування хворих з глибокими термічними та травматичними дефектами верхніх кінцівок

\begin{tabular}{|c|c|c|c|c|c|c|}
\hline \multirow{2}{*}{$\begin{array}{c}\text { Кількість } \\
\text { паціснтів }\end{array}$} & \multicolumn{4}{|c|}{ Результати } \\
\cline { 2 - 7 } & Абс. & $\%$ & Абс. & $\%$ & Абс. & $\%$ \\
\cline { 2 - 7 } & 35 & 61,4 & 18 & 31,6 & 4 & 7,0 \\
\hline 57 & \multicolumn{3}{|c|}{ задовільний } & \multicolumn{2}{|c|}{ незадовільний } \\
\hline
\end{tabular}


TRADITIONAL MEDICINE AND PHARMACOLOGY. ACHIEVEMENTS, INNOVATIONS, AND ALTERNATIVES

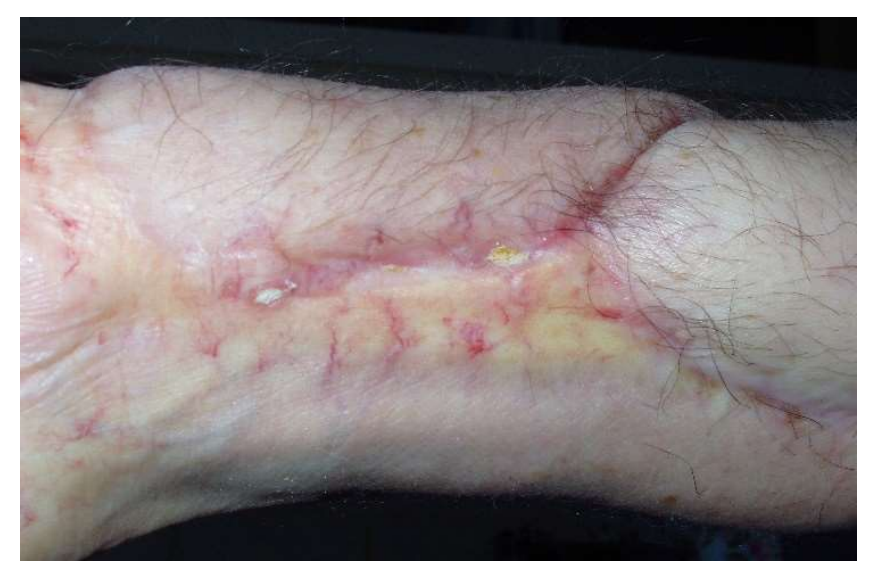

Рис. 42. Добрий результат лікування через 1 рік після пластики променевої виразки лівого передпліччя тильним міжкістковим клаптем на задній гілці міжкісткової артерії.

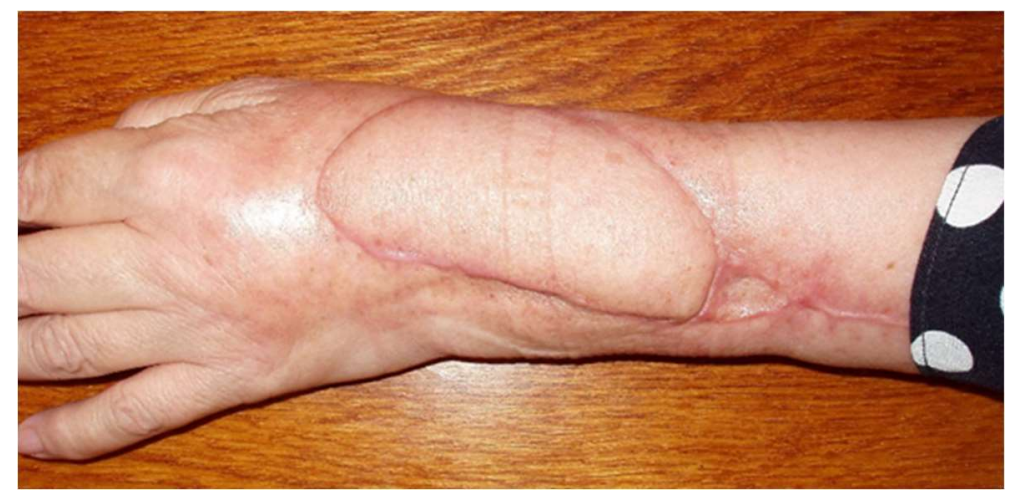

Рис. 43. Добрий результат лікування гнійного дефекту променевозап’ясткового суглоба тильним міжкістковим клаптем на задній гілці міжкісткової артерії.

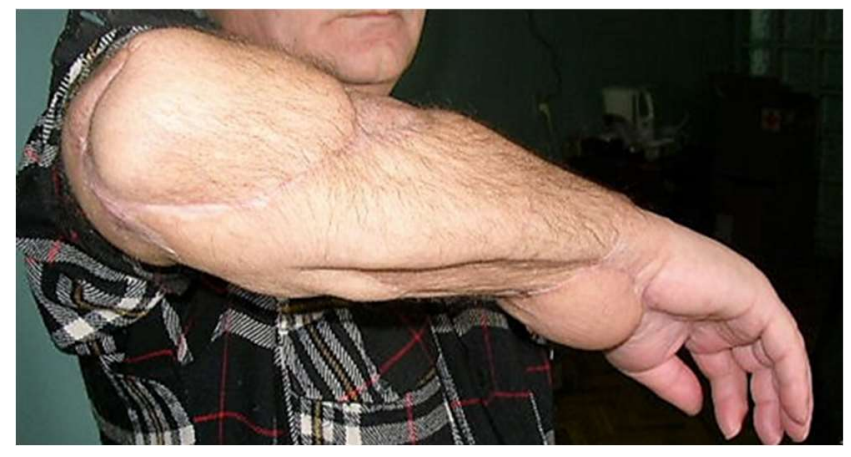

A

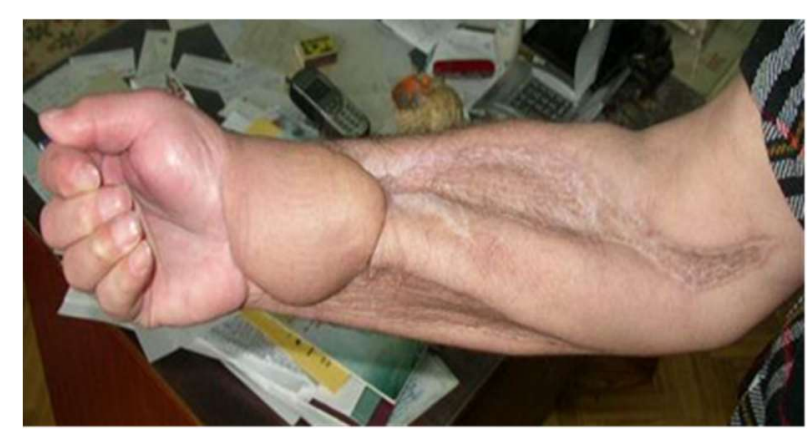

Б

Рис. 44 (А) добрий результат через 1 рік після пластики дефекту бічним клаптем плеча; (Б) задовільний результат через 1 рік після пластики паховим клаптем складного дефекту після ураження електричним струмом. 


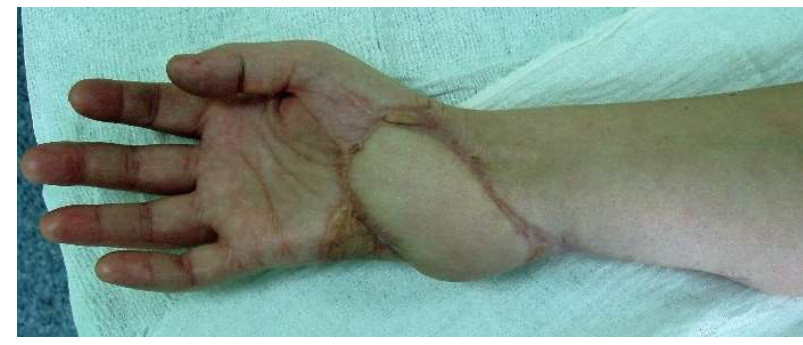

A

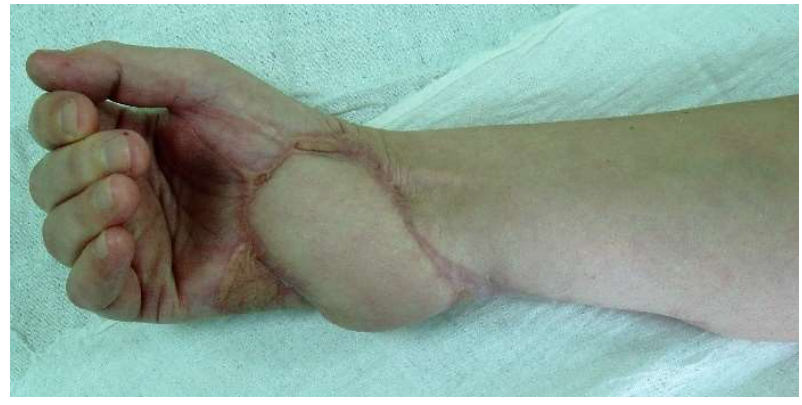

Б

Рис. 45. Задовільний результат лікування дефекту променевозап’ясткового суглоба перфорантним клаптем ліктьової артерії

Таким чином, глибокі дефекти верхніх кінцівок спостерігаються у 24,4\% постраждалих 3 термічною травмою верхніх кінцівок і у 79,6\% випадків виникають внаслідок електротравми та ураженням полум'ям. Такі ураження супроводжуються пошкодженням глибоких анатомічних структур, що призводить до порушень кровообігу та інервації в сегментах кінцівок, втрати функції та інвалідизації постраждалих. Поліморфізм та різномаїття пошкоджень потребують диференційованого хірургічного підходу у кожному конкретному випадку.

\section{Обговорення}

Здійснення превентивних, органозберігаючих та первинно-відновних втручань при глибоких термічних та травматичних дефектів верхньої кінцівки включає основні етапи - видалення нежиттєздатних тканин у ранній період, відновлення анатомічних структур і закриття ранового дефекту за допомогою відповідного виду шкірної пластики.

Однак, методи, що прийняті при лікуванні травматичних ушкоджень для відновлення дефектів у постраждалих з термічними ураженнями малопридатні. Це пов'язано з великою площею ураження покривних тканин, пошкодженням судин, вираженими дегенеративно-дистрофічними змінами та багатьма іншими чинниками [439-441].

Беручи до уваги особливості термічних уражень та уражень електричним струмом зокрема, поліфокальність, ураження судин на значному 
TRADITIONAL MEDICINE AND PHARMACOLOGY. ACHIEVEMENTS, INNOVATIONS, AND ALTERNATIVES

протязі, важкість стану потерпілих, певні переваги повинні належати регіональним та віддаленим, у тому числі "острівцевим" клаптям. Це пов’язано з тим, що тривалість і травматичність таких оперативних втручань невеликі, а надійність прогнозованого ефекту істотно більша, ніж при мікросудинному пересадженні комплексу тканин [441, 442].

Термін виконання пересадки складних клаптів відіграє важливу роль у запобіганні вторинного некрозу глибоких структур. Більшість авторів [443445] дотримуються принципу, що відновлення дефекту, який викликаний термічною коагуляцією i супроводжується ішемізацією тканин, повинно виконуватися в ранній термін повношаровими клаптями, що мають переважно осьовий тип кровопостачання. Це дозволяє сподіватися на феномен реваскуляризації, а точніше - відносної гіпероксидації тканин, що знаходяться в стані гострої або підгострої ішемії. Вчасно й успішно проведені хірургічні втручання найчастіше дозволяють уникнути необхідності реконструктивних втручань у подальшому. Таким чином, невільна шкірна пластика, виконана в ранні терміни після опіку, приймає риси реконструктивно-відновної операції.

В залежності від строків надходження хворих та їх загального стану оперативні втручання повинні здійснюватися у ранні строки на 2 - 10 добу. Втручання в умовах запальних реакцій призводять до загрози розвитку інфекційних ускладнень. У таких випадках необхідно здійснювати новий підхід до лікування, а саме - раннього висічення некротизованих тканин, як джерела інфекції, інтоксикації та причини розвитку опікової чи травматичної хвороби в період до формування демаркаційного валу та закриття утворених ран власними тканинами чи біологічними покриттями.

Вибір тактики лікування термічних уражень верхніх кінцівок в гострому періоді визначається частим ушкодженням глибоких анатомо-функціональних структур (сухожильно-м’язові, кістково-суглобні і судинно-нервові утворення), виникненням дегенеративно-дистрофічних змін, що призводить до труднощів їхнього подальшого відновлення. 
TRADITIONAL MEDICINE AND PHARMACOLOGY. ACHIEVEMENTS, INNOVATIONS, AND ALTERNATIVES

Закрити дефекти м'яких тканин верхньої кінцівки неможливо за допомогою простих методів, таких як загоєння вторинним натягом або первинним ушиванням і слід застосовувати інші методи. Пересадка шкіри вимагає васкуляризованого ранкового ложа для прийому трансплантата і не підходить для покриття дефектів над сухожилками та кістками з відсутністю паратенону або окістя. Крім того, висока можливість виникнення контрактур, рубцевої трансформації та недостатня чутливість обмежують їх успішне використання як основний спосіб реконструкції. Клаптева пластика місцевими тканинами чи вільна пластика клаптями забезпечує власне кровопостачання, тому часто використовується для закриття складних дефектів 3 оголенням сухожиль і кісток. Однак, якщо розглядати місцеві чи регіональні клапті або клапті з віддалених анатомічних ділянок, слід враховувати декілька факторів. По-перше, повинно бути обраний найпростіший метод, який забезпечує адекватний обсяг м'яких тканин і певною мірою гарантує максимальне відновлення чи покращення функції разом 3 найменшою деформацією донорської ділянки. По-друге, при можливості, використовувати тканини близькі по текстурі, кольору та об’єму.

Крім цього необхідно враховувати функціональні і естетичні ділянки верхньої кінцівки, які розділяють руку на окремі регіони, з їх унікальними функціональними та естетичними властивостями.

\section{Висновки}

Широке використання в клініці реваскуляризуючих операцій, поєднання ïx 3 традиційними методами шкірно-пластичних втручань, а також ортопедичних методів фіксації дозволяє значно підвищити ефективність лікування і реабілітації постраждалих. Проведення розробленої програми превентивних, первинно-відновних та органозберігаючих оперативних втручань, дозволяє попередити розвиток рубцевої трансформації тканин, що виникає внаслідок глибоких уражень функціонально важливих ділянок, знизити строки лікування та відмовитися від інвалідизуючої ампутації. 